\title{
Two Approaches to Analyzing Institutions' Spending Responses to Campus Sexual Assault
}

Amanda M. Rose

ampozzuto@mix.wvu.edu

Follow this and additional works at: https://researchrepository.wvu.edu/etd

Part of the Higher Education Commons

\section{Recommended Citation}

Rose, Amanda M., "Two Approaches to Analyzing Institutions' Spending Responses to Campus Sexual Assault" (2020). Graduate Theses, Dissertations, and Problem Reports. 7658.

https://researchrepository.wvu.edu/etd/7658

This Dissertation is protected by copyright and/or related rights. It has been brought to you by the The Research Repository @ WVU with permission from the rights-holder(s). You are free to use this Dissertation in any way that is permitted by the copyright and related rights legislation that applies to your use. For other uses you must obtain permission from the rights-holder(s) directly, unless additional rights are indicated by a Creative Commons license in the record and/ or on the work itself. This Dissertation has been accepted for inclusion in WVU Graduate Theses, Dissertations, and Problem Reports collection by an authorized administrator of The Research Repository @ WVU.

For more information, please contact researchrepository@mail.wvu.edu. 
Two Approaches to Analyzing Institutions' Spending Responses to Campus Sexual Assault

\author{
Amanda M. Rose \\ Dissertation submitted \\ to the College of Education and Human Services \\ at West Virginia University \\ in partial fulfillment of the requirements for the degree of \\ Doctorate of Philosophy in Higher Education Administration
}

\author{
Rodney Hughes, Ph.D., Chair \\ Nathan Sorber, Ph.D. \\ Erin McHenry-Sorber, Ph.D. \\ Miguel Olivas-Lujan, Ph.D. \\ Department of Higher Education Administration
}

\author{
Morgantown, West Virginia
}

2020

Keywords: campus sexual assault, Title IX, revenue theory of costs

Copyright 2020 Amanda Marie Rose 


\begin{abstract}
Two Approaches to Analyzing Institutions' Spending Responses to Campus Sexual Assault
\end{abstract}

\title{
Amanda M. Rose
}

Despite occupying a growing portion in contemporary U.S. higher education institutions' annual budgets, empirical research on sexual assault costs is limited. The purpose of this study is to look at whether incidences of sexual violence on campus are associated with increased costs in policies and programs geared toward prevention of these crimes. Informing the analysis is a theoretical framework consisting of the revenue theory of costs and positional arms race theory. This study examines data from both IPEDS and the U.S. Department of Education Crime and Safety website over a ten year period, 2006-2015, for a set of over 2,300 public and private fouryear institutions and over 1,000 public and private two year institutions. Through the use of multiple regression this dataset will be assessed over time to analyze any changes in spending associated with crime on campus the year prior. In addition, a survey was sent to all available schools' Title IX Coordinators or Director of Student Service personnel. Results of this study found that there is a significant positive association between the number of prior year crime reports and institutions' subsequent spending on student services (e.g. counseling) and institutional support (e.g. addition of personnel). These results will have important implications related to understanding and managing institutional support and student service spending related to sexual assault across U.S. higher education institutions. 


\section{TABLE OF CONTENTS}

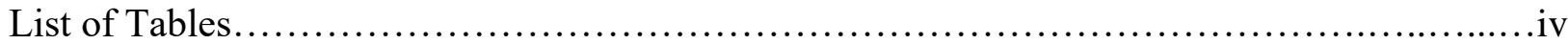

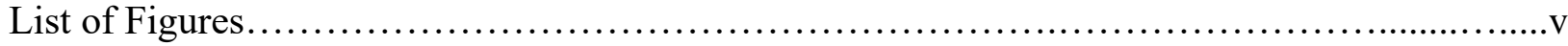

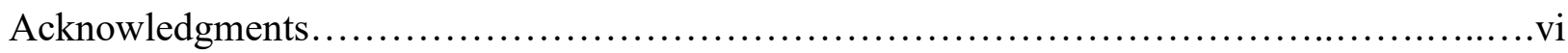

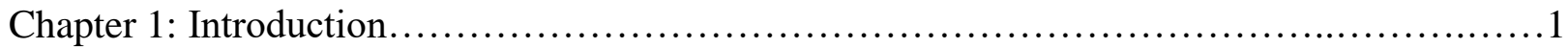

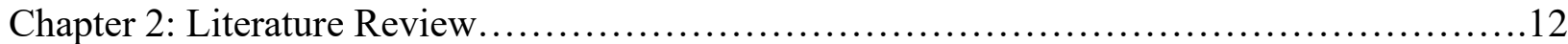

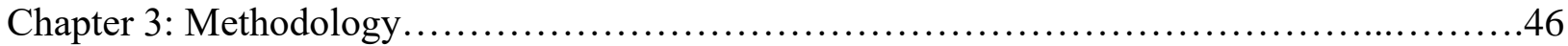

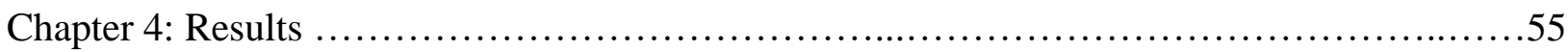

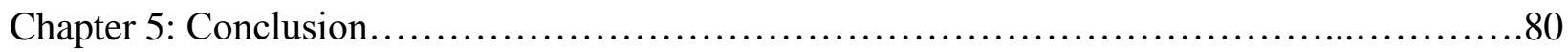

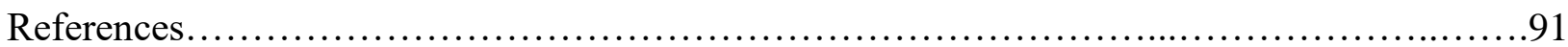




\section{LIST OF TABLES}

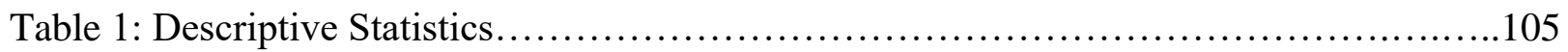

Table 2: Descriptive Statistics by Degree Level ....................................106

Table 3: Student Service Expenditures Regression Results.............................112

Table 4: Institutional Support Expenditures Regression Results.........................114

Table 5: Expenditures Regression Results Before \& After $2011 \ldots \ldots \ldots \ldots \ldots \ldots \ldots \ldots \ldots \ldots \ldots$

Table 6: Student Service Expenditures Regression Results for Institutions of the Same Type or Within the Same State....................................................... 118

Table 7: Institutional Support Expenditures Regression Results for Institutions of the Same Type or Within the Same State...................................................... 120

Table 8: Expenditures Regression Results for Institutions of the Same Type or Within the Same

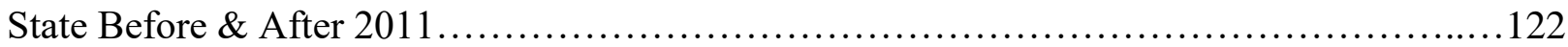




\section{LIST OF FIGURES}

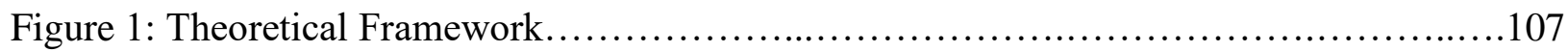

Figure 2: Survey Participant Cover Letter.............................................. 108

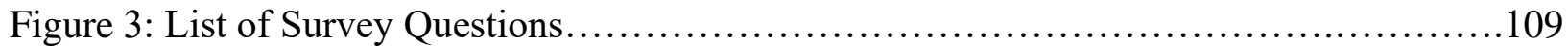




\section{Acknowledgements}

I am grateful for my best friend and husband, Brian Rose, for always being my sounding board and voice of reason. Through all the late night brainstorming sessions, practice runs on presentations, and countless hours of work, you never once complained and instead just encouraged and supported. To my beautiful daughter, Mackenzie, I hope when you grow up you can see that you are my inspiration for everything in life. I love you both to the moon.

To my amazing parents for teaching me from a young age to always reach for the stars and never strive for less. You have both been my role models my whole life and my biggest support system. Dad, thank you for your willingness to proof read any paper I send your way and for teaching me to lead with my heart. Mom, thank you for always being my shoulder to lean on and for never failing to remind me of my true potential. And to my brother, thank you for always believing in me and supporting me. I love you all so much.

To Dr. Rodney Hughes, whose constant encouragement, constructive criticism, and willingness to always talk things through and ask the tough questions helped guide and refine both my thinking and writing. I want to thank Dr. Erin McHenry-Sorber for allowing me the opportunity to work with her and learn survey construction very early on in my studies. To Dr. Nathan Sorber for giving me a chance to prove myself when I decided to transfer into the program. And to Dr. Miguel Olivas-Lujan, for being my sole inspiration for wanting to pursue my doctoral degree. Your guidance throughout my time at Clarion was invaluable.

And finally, to the two educators that left an imprint on my heart forever and helped mold me into the student I am today, Mr. Mickey and Mr. Gonder. Thank you both for showing me that learning can be fun and that hard work and passion will take you wherever you want to go. 
Chapter 1: Introduction 
Even though high rates of sexual assault on college campuses have been a problem since the 1980s (Koss, Gidyzc, \& Wisniewski, 1987; Fisher, Cullen, \& Turner, 2000; McCauley, Ruggiero, Resnick, Conoscenti, \& Kilpatrick, 2009), for many years, the reality of these crimes was hidden, being passed off as more innocent events youthful pranks and innocent events. However, over the past several years, celebrated cases have shone a spotlight on campuses and created a firestorm of controversy and political discussion across the nation (Castellano, 2015). A national survey of 27 U.S. universities found that $11.7 \%$ of student respondents reported experiencing nonconsensual sexual contact either by physical force or incapacitation since enrolling at their university (Cantor, Fisher, Chibnall, Townsend, Lee, Thomas, \& Westat, Inc., 2015). However, only 5-28\% of these victims actually reported their assault to campus authorities or law enforcement officers out of fear of not being taken seriously or the immense amount of shame they felt after the attack (Cantor et. al., 2015). Although it has been found in the past that undergraduate women are the most vulnerable for sexual assault crimes on college campuses (Center for Disease Control and Prevention, 2012; Dekeseredy and Kelly, 1993; Koss, Gidycz, \& Wisniewski, 1987), this survey is pivotal in that it found those identifying as transgender, genderqueer, non-conforming, questioning, or as something not listed on the survey (TGQN) being just as vulnerable. Specifically, more than 1 in 5 female undergraduates and 1 in 5 TGQN undergraduates report being sexually assaulted while in college (Cantor et. al., 2015).

The media is now portraying institutions as dangerous hotbeds for sexual assaults (Fisher, 1995; Fisher, Cullen, \& Turner, 2000) and accusing universities of seriously mishandling the pervasive problem (Lombardi, 2010; Schroeder, 2014; Moylan, 2017; Moylan \& Javorka, 2018) due to studies such as Cantor et. al. (2015) revealing the truth behind campus sexual assault.

\section{Definitions}


Sexual assault It is important to note that the primary difference between campus sexual assaults and sexual assaults committed outside of a college campus is that victims of campus sexual assault have access to two judicial systems (i.e., the criminal justice system and the academic institution) (DeMatteo, Galloway, Arnold, \& Patel, 2015). Formally, sexual violence has been defined as "physical sexual acts perpetrated against a person's will or where a person is incapable of giving consent due to the victim's use of drugs or alcohol or because an intellectual or other disability prevents the student from having the capacity to give consent" (Department of Education, 2019, p. 1). The sexual violence umbrella houses a broad array of activities including sexual harassment, sexual assault, rape, sexual battery, sexual abuse, sexual coercion, and stalking (Campus Sexual Assault: Suggested Policies and Procedures, 2012).

Sexual harassment is defined as a pattern of intimidation or bullying related to one's sex or the act of something sexual in nature (von Spakovsky, 2017). Sexual assault, on the other hand, is a term that applies to a broad range of forced or unwanted sexual activity. Specifically, this term refers to any nonconsensual sexual act proscribed by Federal, Tribal, or state law, including when the victim lacks capacity to consent (Department of Justice, 2019). Koss et. al. (1987; p. 166) uses a four-type classification system for addressing sexual assault. The first of these classifications is sexual contact, which includes unwanted sex play, such as fondling or kissing, arising from verbal pressure, the misuse of authority, or actual physical force (Koss et. al., 1987). The second classification, known as sexual coercion, includes unwanted sexual intercourse, which also tends to arise from either verbal pressure or the misuse of authority. Attempted rape, the third classification, includes any unwanted sexual intercourse stemming from the use of threats or physical force, and/or drugs or alcohol (Koss et. al., 1987). And lastly, rape, which is the most serious type of sexual assault, is broadly defined as penetration, no 
matter how minimal, of either the vagina or anus, with any body part of animate object, or oral penetration by other person, without the consent of the victim (Koss et al., 1987).

Each state tends to adopt their own version of this definition, which may differ from one state to the next (von Spakovsky, 2017). This form of violence is very serious and traumatic in that the outcomes for victims range from anxiety and depression to unwanted pregnancy to sexually transmitted diseases (Kilpatrick \& Acierno, 2003; Petrak, 2002; Ullman \& Brecklin, 2003, Zinzow, Resnick, Amstadter, McCauley, Ruggiero, \& Kilpatrick, 2010). This crime is so serious that behind murder, rape is the most feared crime by women (Brodyaga, Gates, Singer, Tucker, \& White, 1975).

Cost \& compliance Along with this fear that students of sexual assault must live with, these crimes are placing a financial cost on universities as well. Throughout this paper, cost will be defined in terms of tangible cost, including those spent to prevent and respond to sexual violence. These costs include those related to medical and mental health care, victim services, career guidance, and even logistic services such as public relations, to name just a few.

Some of these costs may be accrued by institutions as they try to stay compliant with sexual assault federal legislation. Compliance is defined in this study as meeting the expectations of standards or regulations from an outside governance or oversight body. For example, Title IX defines an institution as compliant if they respond to and resolve sexual assault claims that are sufficiently serious to deny or limit a student's success at the institution (Department of Education, 2014).

\section{Purpose}

The purpose of this study is to look at whether incidences of sexual violence on campus are associated with increased costs in policies and programs geared toward prevention of these 
crimes. While much of the public discussion about the impact of campus sexual assault cases in recent years has focused on the toll of victims (Tate, 2017), including how to define consent, how to measure the reliability of the accusers, and even how to punish those responsible (Nelson, 2015), college leaders are growing more concerned about the financial impact on their institutions. For example, on average, universities lose $\$ 350,000$ related to sexual assault claims, Alex Miller, Associate Vice President of Learning Programs in the Risk Management Department of United Educators, has said (Tate, 2017, p. 5). While few researchers have directly studied costs, this is an important aspect for higher education institutions to understand so administrators can make informed decisions on how best to make their institutions most cost effective (Cheslock, Ortagus, Umbricht, \& Wymore, 2016).

With the revenue sources that sustain colleges and universities being so unstable, this is a crucial aspect for administrators to understand. The present study aims to contribute new evidence around institutions' initial responses to campus sexual assault and other crimes by investigating the relationship between crime reports and institutional spending on measures like student services and institutional support. With a major highlight of this study being the analysis of an institution's response both before and after the issuance of the Dear Colleague Letter in 2011, to assess whether or not there are any differences, this work comes at a pivotal time as it may help shed some light on the importance of this guidance as the Department of Education is once again debating it.

\section{Title IX}

Until 2011, intercollegiate athletics dominated the debate over Title IX (Melnick, 2018). In 2011, sexual harassment became the most pressing controversy when the Obama 
administration announced detailed sexual-harassment rules and introduced a Dear Colleague Letter (Carroll, Dahlgren, Grab, Hasbun, Hayes, \& Muntis, 2013).

Dear Colleague Letter (DCL) This Dear Colleague letter, which was issued by the Obama administration following an in depth investigation by the Center for Public Integrity on Campus Assault, was intended to remind colleges that sexual assault creates a hostile environment for victims which impacts their access to education and violates their civil rights (Joyce, 2017). Although this letter did not offer schools a uniform policy on how to best handle sexual assault cases, it did offer recommendations that schools can use to remind students how to stay safe and avoid potentially dangerous situations. One specific example the letter laid out was for schools to inform students that drinking never makes the survivor at fault for sexual assault or harassment and discouraging colleges from allowing either party in a sexual assault case to cross-examine the other during investigations (Joyce, 2017).

This Dear Colleague Letter was a chance for the federal government to dictate the specific procedures that colleges must use to decide student-to-student sexual assault allegations (Johnson \& Taylor, 2017; Moylan, 2017; Schroeder, 2014; Johnson \& Taylor, 2017). While this letter introduced a reinterpretation of Title IX, critics soon brought to light the overwhelming reduction to students' due process rights that they felt came along with it (Johnson \& Taylor, 2017). Some of the specifics mentioned as reducing a student's due process were the "preponderance of evidence" standard, which stated if it was more than likely that sexual assault occurred, there should be a punishment and the fact that institutions were now required to allow accusers to appeal not-guilty findings (Johnson \& Taylor, 2017). While the Dear Colleague letter made clear that the federal government would aggressively monitor institutions and marked a 
new era of strict enforcement, the 2014 Q \& A addressed in further detail how colleges should bring their policies and practices into compliance with Title IX.

Call for change As these questionable responses by academic institutions started to come to light, several groups began calling for change (DeMatteo et al., 2015). As both student victims and parents alike found their voice, institutions were being prompted to initiate policy change and seek guidance on how to reduce incidences of sexual assault and better handle cases that do arise (McCaskill, 2014). These calls for change have also caught the attention of lawmakers, at both the state and federal level, who are now directing some efforts at reducing the number of reported sexual assaults on campuses by strengthening existing legislation and enacting stronger laws (DeMatteo et al., 2015). For universities that wish to avoid negative impacts to their reputation and financial well-being, lawmakers are sending a message that the time is now to become compliant and avoid the potential for fines, lawsuits and unflattering media coverage (Moylan, 2017). Unfortunately, not everyone is on board. For example, research shows that there were 55 institutions on the U.S. Education Department's initial list of schools under federal investigation for Title IX violations regarding both their response to and reporting of sexual assault cases on campus (Moylan, 2017), with this number growing under the Obama administration to roughly 350 cases (DeSantis, 2017).

To try and resolve some of these active cases in a more time sensitive fashion, the U.S. Department of Education decided to shift their approach to enforcement of campus sexual assault policy (Zamudio-Suarez, 2017) starting with revocation of these two pivotal pieces of guidance, the Dear Colleague letter issued in 2011 and the 2014 questions-and-answers document that provided additional guidance to higher education institutions on how to report these acts. 
Trump administration Now, with changes coming from the DeVos Department of Education in 2017, it was announced that the era of rule by letter is over (Melnick, 2018). Title IX under the Trump administration now requires colleges and universities to conduct a prompt, thorough and impartial investigation into any and all allegations of sexual assault (Camera, 2017), whether or not the incident occurred on school grounds. While the Trump administration's new policies on college sexual misconduct could drastically change how institutions handle sexual assault claims (Kitchener \& Harris, 2018), it is thought that a majority of schools may maintain the same, stricter Title IX policies they had under the Obama administration (Kitchener \& Harris, 2018). While at first being hesitant to loosen up in fear of appearing lax on the issue of sexual assault, eventually schools will find themselves dealing with more wiggle room in how they enforce their policies. With these new policies in place, institutions may no longer have to fear major lawsuits from the federal government if they choose to decrease their attention to campus sexual assault (Kitchener \& Harris, 2018).

\section{Research Questions}

While the implications of these policy changes are still being explored in the courts (Melnick, 2018), the institutional effects stemming from them are already being felt. In order to address the fallout stemming from these policy changes, four research questions will be addressed in this study, including:

RQ1: Is there a positive association between the number of reported crimes and sexual assaults and institutions' subsequent spending on student services (i.e., counseling)? 
RQ2: Is there a positive association between the number of reported campus crimes and sexual assault and institutions' subsequent spending on institutional support (i.e., compliance)?

RQ3: Did the association between campus sexual assault and institutional spending change with the 2011 issuance of the Dear Colleague Letter on sexual assault response?

RQ4: Is there a positive association between spending on student services or institutional support at one institution and the crimes or spending decisions at local institutions?

RQ5: Is there a positive association between spending on student services or institutional support at one institution and the crimes or spending decisions at peer institutions?

\section{Outline}

In chapter two of this dissertation, the prevalence of sexual assault on college campuses and the contributing factors of these assaults will be addressed in in-depth. These crimes will be discussed by race, sex, a student's year in college, the time of year, and social factors (e.g. drugs and alcohol). The ongoing problem of under-reporting sexual assault will be discussed before the conversation transitions to federal legislation. Currently, there are three main federal pieces of legislation that address campus sexual assault, including: (1) Title IX, (2) the Clery Act, and (3) the Campus SaVE Act. This chapter is wrapped up with a discussion of campuses response to sexual assault according to the 2004 California Blueprint (Lichty, Campbell, and Schuifeman, 
2008). This blueprint defines best practices in campus-based responses to sexual assault specifically detailing five minimum components for developing a successful campus response.

In chapter three, each of the four research questions will be addressed through multiple regression with the use of Stata using both crime data and financial data. In order to obtain this data two primary data sources were used, including both the U.S. Department of Education Crime and Safety and the Integrated Postsecondary Education Data System (IPEDS). This data will be analyzed over a ten year period of time, 2006-2015, for public and private, two and four year institutions. To help ease some of the concerns surrounding the validity of the data and its ability to actually pinpoint how much funding is being contributed to sexual assault funding, a quantitative survey will be distributed to all viable institutions' designated Title IX coordinators or Director of Student Services contacts, in hopes of learning more about institutional responses attributed to sexual assault funding in regards to both institutional support and student services.

For institutions that are not forthcoming regarding a specific Title IX contact, a student services contact was chosen because these staff members are trained to balance the holistic education and care of individuals with the need for campus safety and accountability. These campus administrators pride themselves on creating environments that promote respect, civility, and even equity and positive relationships and because of this are more often than not trained to properly address any sexual assault complaints brought to their attention.

In chapter four, the results of the analyses will be addressed in-depth. First, the survey analyses will be discussed after a brief discussion of how the coding of the responses was conducted. Then, the regression analyses are discussed in sections. First, the main findings are presented, then the results for before and after the Dear Colleague Letter, then the competition analysis results and finally those coming from other predictors. 
In the last and final chapter, chapter five, the findings of this study are interpreted and implications from these are discussed based around research, practice, and policy. Throughout these implications, limitations of the study and areas for future research will be touched upon. This chapter is then concluded with a brief summary of the entire study. 
Chapter 2: Literature Review 
The following chapter is meant to educate readers on the prevalence of sexual assaults on college campuses based on ones descriptors such as gender, age, or race. Contributing factors such as alcohol and drugs or time of year are then summarized as support for the prevalence statistics presented prior. As a way of structuring my argument and placing emphasis on the Dear Colleague Letter, the main three areas of legislation for sexual assaults are then discussed in depth. These include: (1) Title IX, (2) the Clery Act, and (3) Campus SaVE Act. Then an institution's possible response to these crimes is framed using the 2004 California Campus Blueprint. This framework leads to a discussion on how the increased number of sexual assaults reported on campus each year is related to the rising cost of institutions. This chapter is then concluded with a discussion of theoretical framework, utilizing both Bowen's (1980) revenue theory of costs and Franks' (1999) positional arms race theory.

\section{Prevalence of Sexual Assaults}

One of the most highly cited foundational pieces in the sexual assault literature is the Koss et. al. (1987) study. Through the use of a national sample of students, these authors were able to study the scope of rape on college campuses, which was one of first studies to do something of this nature. The results from this study indicate that since the age of $14,27.5 \%$ of college women reported experiencing an attempted rape or being raped, whereas $7.7 \%$ of college men reported perpetrating one of these heinous crimes (Koss et. al., 1987). However, the authors were quick to note that these rates may not tell the whole picture, as the ratio of rapes to occur vs. those reported is 1 to 3 (Koss et. al., 1987).

While reported prevalence statistics of sexual assaults on college campuses have varied widely over the years (Yung, 2015), one thing that all studies have in common is the notion that sexual assault on college campuses is a pervasive problem. Researchers have shown that women 
are far more likely to be sexually assaulted than their male peers and that males are the most frequent to be labeled a perpetrator of these crimes (Fisher et al., 2010; Perrin, Vandeleur, Castelao, Rothen, Glaus, Vollenweider, \& Preisig, 2014). Several national studies suggest that sexual assault is a significant problem affecting approximately $15-25 \%$ of college women who become victims of rape or attempted rape before their senior year (Carey, Durney, Shepardson, \& Carey, 2015; Center for Disease Control and Prevention, 2012; Dekeseredy \& Kelly, 1993; Fisher, Sloan, Cullen, \& Lu, 1998; Fisher, Cullen, \& Turner, 2000; Koss et. al., 1987; Krebs, Lindquist, Warner, Fisher, \& Martin, 2009; Muehlenhard \& Linton, 1987). During any given academic year this equates to approximately $2.8 \%$ of women experiencing a completed or attempted rape (Fisher et. al., 2000; Karjane, Fisher, \& Cullen, 2005). Broken down even further this amounts to approximately one in five female students experiencing one or more sexual assaults during their college tenure, or one in four if attempted rape is factored in (Fisher et. al., 2010; Krebs et al., 2009), defined as sexual penetration or touching by physical force or incapacitation (Krebs, Lindquist, Warner, Fisher, \& Martin, 2007). Although the "one in five" statistic stems from one of the most widely cited prevalence studies (Krebs et al., 2007), more recently Muehlenhard, Peterson, Humphreys, and Jozkowski (2017) found that this statistic can be misleading. The authors argue that this statistic over simplifies sexual assaults by disguising crucial differences in risk for sexual violence, such as "campus, year in school, sexual orientation, gender identity, race, and disability status" (p. 19).

Women are not the only gender affected by these acts, as sexual assault continues to be a serious problem among all young people age 18-24. Males enrolled in college are also $78 \%$ more likely than non-students of the same age to be a victim of rape or sexual assault (Department of Justice, 2014), leaving a total of $5.4 \%$ of these students as victims. Several studies have also 
showed that students who identify as part of the lesbian, gay, bisexual, transgender, and queer (LGBTQ) community experience similar or even higher rates of sexual victimization when compared to heterosexual students (Coulter \& Rankin, 2017; Ford \& Soto-Marquez, 2016). Similarly, the Rape, Abuse, and Incest National Network (RAINN), found that nearly $21 \%$ of transgender, genderqueer, and nonconforming (TGQN) college students have been sexually assaulted, compared to $18 \%$ of non-TGQN females, and $4 \%$ of non-TGQN males (Cantor et. al., 2015). Other groups that have been identified as high-risk for sexual assault include students with disabilities (Findley, Plummer, \& McMahon, 2016; Scherer, Snyder \& Fisher, 2016) and Native American students (Patterson Silver Wolf, Perkins, Zile-Tamsen, \& Butler-Barnes, 2016). Conversely, international students have been identified as a lower-risk for sexual assaults than the groups previously mentioned (Daigle, Hoffman, \& Johnson, 2016).

When it comes to black student experiences the literature seems to have mixed results. While Krebs, Lindquist and Barrick (2011) found lower rates of sexual assault at historically Black colleges and universities (HBCUs) and evidence to support the notion that Black students experience lower rates of sexual assault on campus than their Caucasian peers, others have found that Black students experience higher rates (Coulter \& Rankin, 2017). Unfortunately, all of these statistics are probably highly underreported as most victims of assault fail to report these crimes to the law (Schroeder, 2014). For example, RAINN (Rape, Abuse, and Incest National Network) reported that $46 \%$ of rapes and sexual assaults ever get reported (RAINN, 2019), which equates to about one in two victims of sexual assault ever reporting their assault to law enforcement (Mancini, Pickett, Call, \& Roche, 2016). Although sexual assault is a highly underreported crime, reporting rates on college campuses are even lower for fear of embarrassment, confidentiality concerns, fear of reprisal, and even fear of being taken seriously and not shamed 
(Fisher, Daigle, Cullen, \& Turner, 2003; Sabina \& Ho, 2014; Sinozich \& Langton, 2014; Sloan, Fisher, \& Cullen, 1997; Wolitzky, Resnick, Amstadter, McCauley, Ruggiero, \& Kilpatrick, 2011; Zinzow \& Thompson, 2011). Specifically, it has been found that only $13 \%$ of college sexual assaults get reported (Sabina \& Ho, 2014; Wolitzky et al., 2011), with some authors reporting an even graver reality of less than 5\% (Campus Sexual Assault: Suggested Policies and Procedures, 2012). This low percentage rate may be due to the fact that only $49.2 \%$ of victims believe it is very or extremely likely that a fair investigation would occur if reported (Cantor, Fisher, Chibnall, Townsend, Lee, Bruce, \& Thomas, 2017).

\section{Contributing Factors to Assault}

College campuses are particularly prone to sexual assaults because large concentrations of young women come into contact with young men in a variety of different settings and social gatherings. It has been documented that more than $50 \%$ of sexual assaults on campus happen between August and November, a span of time sometimes referred to as the "red zone" (Kimble, Neacsiu, Flack Jr., and Horner, 2008). During this time, college students, especially women, are thought to be at a heightened risk for unwanted sexual experiences because this period of time is often times finds students who have very little experience drinking and very few friends to watch out for them consuming a large quantity of alcohol (Aggeler, 2017). Once students gain a circle of social support, their chances of being sexually assaulted lower (Conley, Overstreet, Hawn, Kendler, Dick, \& Amstadter, 2017).

Although a majority of sexual assaults documented during this period of time occurred when women were alone with a man they knew, at night (Gordon \& Riger, 1989), and in the privacy of a residence (Fisher et. al., 2000), a growing number of sexual assaults on campus are occurring at fraternity houses, especially gang-rapes, as these residencies are occupied by same- 
age, same-sex peers whose maturity and judgement is often less than ideal (Martin and Hummer, 1989; Murnen \& Kohlman, 2007). A lot of the sexual assaults that occur at fraternity parties are labeled alcohol and/or other drug (AOD)-enabled sexual assault (Krebs et al., 2009), where the victims are assaulted when they are incapacitated because of their voluntary and/or excessive use of alcohol and/or drugs. Specifically, research shows that $35.2 \%$ of college women who reported an assault in the National Crime Victimization Survey (NCVS) in 2014, made note of alcohol or drugs being involved (Rennison \& Addington, 2014). Fraternity houses are also hot-beds for sexual assault as they create a hook-up environment (Flack, Hansen, Hopper, Bryant, Lang, Massa, \& Whalen, 2016) and they create a double standard in that men who have sex are studs and women who have sex are sluts (Burnett, Mattern, Herakova, Kahl, Tobola, \& Bornsen, 2009). Even as far back as 1990, alcohol use has been found to be a significant contributor to sexual assaults on campus, regardless of race (Abbey, 2011; Meilman, Riggs, and Turco, 1990; Mohler-Kuo, Dowdall, Koss \& Wechsler, 2004), with $85 \%$ of all students reporting alcohol was involved (Nicholson, Maney, Blair, Wamboldt, Mahoney, \& Yuan, 1998).

Other widely accepted associations to sexual assault on campuses are membership in athletic teams (Murnen \& Kohlman, 2007) and rape-myth acceptance (Bannon, Brosi, \& Foubert, 2013). Rape myths, as defined by Burt (1998; p. 217), are referred to as, "prejudicial, stereotyped, or false beliefs about rape, rape victims, and rapists”. Some of the most common rape myths are that only certain type of women are raped, the victim brought on the assault through her own carelessness, the victim lied, the perpetrator was entitled to have sex with the victim, the accused didn't mean to rape her, and the woman was dressing too sexy (Payne, Lonsway, \& Fitzgerald, 1999). These rape myths set a foundation for victim blaming by creating the notion that no actually means yes (Ray, 2013). Rape myths also have damaging affects to 
men, painting them as a sex crazed gender who always wants intercourse, which isn't the case (Ray, 2013).

With colleges and universities being legally obligated to create and maintain a safe campus environment (Baker \& Boland, 2011) as these assaults continue to be highly publicized and criticized by media outlets, both the White House and the Department of Education (DOE) are on alarm and are now investigating upwards of 100 colleges and universities for possible Title IX violations (Howard, 2015). The persistence of rape culture contributes to policies regarding reported rapes to be so flimsy, which is what ultimately gets campuses off track in regards to federal mandates (Ray, 2013).

With fear of repercussions being one reason institutions see underreporting of sex crimes, states like Wisconsin have been trying to combat the problem by tailoring their prevention measures. For example, in 2016, Wisconsin passed legislation referred to as the Assembly Bill 808 to prohibit victims of sexual assault from being fined for underage drinking in hopes that college students would be more willing to come forward and report a crime on campus.

\section{Legislation}

During the 1980s, the nation saw its first campus crime and statistics reporting law passed, the Pennsylvania College and University Security Information Act of 1988 (Sloan et al., 1997). Along with this, systematic reports regarding campus crime kept appearing in popular media outlets, such as the Chronicle for Higher Education (eg., Blumenstyk, 1989) and caught the attention of the federal government and thus began the national conversation of sexual assaults on college campuses. Following numerous amendments, today there are three pieces of federal legislation that address campus sexual assault. These three pieces include: (1) Title IX, (2) the Clery Act, and (3) the Campus SaVE Act (which amended the Clery Act). Taken 
together, these three pieces address the obligations institutions have to address allege sexual assaults that occur on campus and the transparency they are to maintain when reporting said crimes (Glass, 2013; Moylan, 2017).

Title IX Title IX was signed into law in 1972 by President Nixon with the primary purpose of encouraging higher education institutions to eliminate sex discrimination by denying institutions federal funding if they support it (Novkov, 2015). This federal civil rights law that prohibits discrimination on the basis of sex, stating that "no person in the United States shall, on the basis of sex, be excluded from participation in, be denied the benefits of, or be subjected to discrimination under any education program or activity receiving Federal financial assistance..." (Title IX, 2006, 20 U.S.C. 1681).

Originally Title IX was designed to open the doors of educational opportunity to women and it worked (Melnick, 2018). At the beginning, Title IX was not designed to resolve claims of sexual assault on college campuses (Henrick, 2013; Silbaugh, 2015; Streng \& Kamimura, 2015), but by 2000, both the Office of Civil Rights and Supreme Court had expanded the breath of the law to include cases of sexual assault in higher education settings (Cantalupo, 2011) based on the premise it interferes with victims' access to equal education (DeMatteo et al., 2015; Moylan, 2017). ). Through this expansion of Title IX's breath, institutions were encouraged to report these crimes, clearly define sexual assault, and adequately explain their policies and procedures around sexual assault to students through programs such as orientation for new students or training for those individuals more likely to come into contact with victims and perpetrators. However, numerous institutions have failed to comply with these standards.

Obama administration On April 4, 2011, President Obama and his Education Department reinterpreted Title IX in the form of a "Dear Colleague Letter" (Moylan \& Javorka, 
2018) that gave the federal government authority to dictate the specific procedures that colleges must use to decide student-to-student sexual assault allegations (Johnson \& Taylor, 2017; Moylan, 2017; Schroeder, 2014). While the federal backing received under the Obama administration illustrated a useful approach at how to combat this problem, unfortunately a backlog of cases exploded under this presidency, to total roughly 350 cases (DeSantis, 2017). Many researchers are attributing this backlog to numerous drafting defects that the letter suffers from (Henrick, 2013). This Dear Colleague Letter not only effectuated a presumption that all accused students are guilty (Henrick, 2013), but it also lowered the burden of proof in campus sexual assault trials to the beyond reasonable doubt standard (i.e., the preponderance of evidence standard, meaning a $50.1 \%$ chance that the accused is responsible is required; New, 2016), required schools to accelerate their adjudications, and eliminated cross-examination of accusers (Johnson \& Taylor, 2017).

The Dear Colleague letter has left institutions not only facing stricter response requirements in the wake of a scandal, but also a greater cost of compliance. This cost of compliance comes with requirements for hiring Title IX coordinators who can help institutions place more attention on institutional responses to these sexual assault cases. Institutions are also facing higher investment cost into student services with the ultimate goal of helping both the accused and victim's process these events and allow for all reports to be handled adequately and timely. While improving campus life for their own students is first and foremost, institutions might also try to proactively learn from incidents at similar institutions or directly use student services to compete with these institutions for prospective students.

Along with this Dear Colleague Letter, institutional attention to this problem was also increased due to pressure from a White House Task Force (White House Task Force to Protect 
Students From Sexual Assault, 2014) and Title IX investigations by the Department of Education (U.S. Department of Education, 2014). As part of this Task Force, President Obama also launched the It's on Us campaign where the agenda was to raise awareness of the prevalence of sexual assault on college campuses (Somanader, 2014). As part of his campaign, President Obama called on campus law enforcement agencies to play a central role in preventing these crimes on campus (Oehme, Stern, \& Mennicke, 2015). The task force also published the Not Alone report (Streng \& Kamimura, 2015) which holds colleges and universities accountable for preventing sexual assault through the implementation of stricter and straighter forward policies.

Title IX compliance costs Under Title IX, institutions are held responsible for monetary damages if a student was assaulted by a faculty or staff member, or another student, and the institution had jurisdiction over both the accused party and the environment in which the alleged attack occurred (Oehme, Stern, Mennicke, 2015). According to the Department of Education, in order for a student to claim any form of monetary relief under a Title IX investigation, however, the victim must prove that the institution had actual knowledge of the alleged assault, but failed to act accordingly upon learning of this information (Lentz, 2013). Unfortunately this standard is very difficult to meet because students rarely have access to the required information needed to prove their academic institution had proper knowledge of the incident (Lentz, 2013). Although difficult, it is not impossible. To address this, researchers have advocated for improving intersectional counseling to promote sexual assault prevention and reporting, improving physical and mental health services to boost disclosure of sexual assault, and improving sexual assault policies and procedures to improve reporting (Taylor, 2018).

For example, two University of Colorado Boulder students who filed suit against their institution for knowing the risk of sexual harassment against female students in connection with 
the football recruiting program, won. These two female students were able to prove the university knew the risks involved, but failed to take any action before their assaults occurred and ultimately were awarded $\$ 2.85$ million between the two of them as part of a settlement with the university (Schroeder, 2014). Along with paying these victims, Colorado also had to pay attorney's fees and injunctive relief in the form of a Title IX advisor who was hired to make recommendations regarding the final decision in any university sexual assault case (Oehme et al., 2015). A similar case occurred at the University of Connecticut, when the university was sued by five students for their negligent handing of their sexual assault cases. Ultimately, the five students prevailed and were collectively awarded \$1.3 million (Oehme et al., 2015). Although the university still adamantly denies the claims, they did acknowledge that this victory sparked a public conversation around sexual assault and took preventative action for the future. Specially, the campus created a position called the assistant dean of student positions for victim support services, added staff investigators to the payroll, and even created their very own Special Victims Unit on campus, which is housed within the police department (Oehme et al, 2015).

Clery Act Another federal law that intersects with Title IX is the Clery Act. This act stems from the first case that caught the eye of the media and really catapulted the issues of campus crime and lax security in the spring of 1986 (Fisher, 1995). In April 1986, Jeanne Clery was raped and tortured before being murdered in her dorm room while she was sleeping (Dunn, 2013). The student-perpetrator was able to commit this crime due to three residence hall doors being left propped open during the evening. Jeanne's parents felt that this crime could have been avoided had they been made aware of the 30 violent offenses that had occurred on Lehigh's campus over the previous three years, but this information was only presented to them after their daughter was found mutilated and they filed a lawsuit against the school (Dunn, 2013). The 
Clery's argued that they sent their daughter to Lehigh under false pretenses believing it was a safe campus.

After settling the subsequent litigation out of court, Jeanne's parents used the money they won to found the national non-profit Security on Campus, Inc. (Dunn, 2013). Through this nonprofit, Jeanne's parents also became instrumental in passing the nation's first campus security reporting law, as well as the federal Student-Right-to-Know and Campus Security Act of 1990 (Fisher, 1995; Fisher et. al, 2000). This legislation was signed into law by President George H.W. Bush in 1990 (Dematteo et. al., 2015; Janosik, 2001) and mandates that colleges and universities participating in federal student aid programs prepare, publish, and distribute an annual security report containing both campus crime statistics and campus security policies (Fisher et. al., 2000; Janosik \& Plummer, 2005: Moylan, 2017; Nicholson, Maney, \& Wamboldt, 1998; Sloan et al., 1997). Because this act is tied to federal student financial aid programs, it applies to most higher education institutions, including both public and private (Schroeder, 2014). This act specially mandates institutions to make publicly available all reports of crimes occurring "on campus", which is defined under the act as on school grounds or sometimes on property owned or controlled by the University (Clery Center, 2017). With most campus-related rapes believed to take place off campus, this limiting definition leaves a lot of assaults to go unreported (Lombardi, 2010). For example, in 2008, Florida State recorded just nine sexual offenses on or near campus, as compared to 48 off (Lombardi, 2010).

Believing this legislation failed to acknowledge the rights of victims of sexual assault, Congress amended the act in 1992 to include the Campus Sexual Assault Victim's Bill of Rights (DeMatteo et al., 2015; Fisher et. al., 2000). Finally, with the 1998 amendment, which included additional reporting obligations and security related provisions for institutions; this act was 
renamed after Jeanne herself and still today is referred to as the Jeanne Clery Disclosure Act. Under the Clery Act, colleges and universities are required to notify survivors of counseling resources and provide them with academic or living accommodations, while some schools take this a step further and add elements that incorporate their own personal campus-specific responses (Karjane, Fisher, \& Cullen, 2002).

Under the Clery Act, institutions must not only publicly publish an Annual Security Report every October 1, detailing the institution's crime statistics for the previous three years, but they also must keep a public crime log documenting the nature, date, time, and general location of each incident (Moylan, 2017; Schroeder, 2014). Similar to the Annual Security Report, the ongoing crime log must be made available to the public and contain all relevant information for any incident within a 60 day time frame. Institutions must also disclose crime statistics for all forcible and non-forcible sex offenses occurring not only on campus, but in public areas adjacent to campus and some non-campus facilities such as Greek housing (Schroeder, 2014). Lawmakers hoped that by institutions sharing this information with the public, students could use it as a factor when weighing college options (Janosik \& Gregory, 2003).

The policy was once again amended in 2013 and broadened to include additional reportable crimes and prevention education programming (Moylan \& Javorka, 2018). Formally, this new amendment to the act is referred to as the Violence against Women Reauthorization Act (VAWA). VAWA was originally enacted in 1994 as a landmark piece of legislation that sought to improve responses to and punishments for domestic violence, sexual assault, stalking, and dating violence (National Domestic Violence Hotline, n.d.). Through the passing of this piece of legislation, Congress provided support for rape crisis centers and domestic violence shelters that 
work every day to help victims of these crimes. Specifically, protection for battered immigrants and underserved populations, including Native Americans were at the forefront of this act (National Domestic Violence Hotline, n.d.).

Although VAWA was originally enacted in 1994, over the years it has been reauthorized in 2000, 2005 and then most recently in 2013 (Oehme, et. al., 2015). In 2000, Congress improved on the 1994 enactment of this legislation by expanding the umbrella of what classifies as dating violence and stalking, creating supervised visitations for families coping with violence, and further protecting underserved populations who are victims of sex trafficking or who are experiencing dating violence or sexual assault (National Domestic Violence Hotline, n.d.). In 2005, Congress decided to take a more holistic approach to addressing these types of violence through the creation of proactive prevention measures, the first federally funded monetary support for rape crisis centers, and by widening the breath of VAWA to now include teenagers and children (National Domestic Violence Hotline, n.d.). As part of an initiative under VAWA, the nation also saw its first Sexual Assault Services Program come to light in 2005, granting victims of sexual assault direct services (Oehme et. al., 2015). These sexual assault direct services include funding for coalitions that provide training and technical assistance to ensure high quality services for victims, accompaniment through medical or criminal justice systems, and advocates (National Domestic Violence Hotline, n.d.).

This latest rendition of VAWA was signed into law by President Obama (DeMatteo et al., 2015) to address some flaws in the Clery Act and to increase the reporting of these violent crimes on campuses. VAWA specifically expanded grant programming targeting these violent crimes and the requirements for the disclosure of campus safety policies in order to raise awareness about these gender-based crimes and establish rights of protection for the both the 
accused and the accuser (Violence Against Women Reauthorization Act, 2013). VAWA

provides funding for innovative programs which specifically target issues such as rape awareness and prevention, stalking, and interpersonal violence (Oehme, et. al., 2015).

Even with all the amendments, many critics still find the Clery Act and similar legislation to be very flawed. For example, Yung (2015) found that when institutions are being investigated for Clery reporting violations, the number of reported sexual assault cases tends to increase, but as soon as the investigation wraps up this number significantly lowers again. Specifically, Yung (2015) found that schools were reporting sexual assault at a $44 \%$ higher rate during the investigation by the Department of Education than prior submissions, but as soon as the investigation is complete reporting rates drop back down to pre-investigation levels. This finding is very important in that it suggests the effect of regulatory oversight only being temporary and that the forces leading to undercounting of campus sexual assault cases persist even when these temporary oversights exist. Similar research has shown that of the roughly $80 \%$ of institutions that submit an annual Clery report, only $66 \%$ include crime statistics and even more worrisome is the fact that only $37 \%$ submit a report that is fully compliant with Clery requirements (Karjane et al., 2005). One of the biggest criticisms stemming from this piece of legislation is that it solely requires reporting on campus sexual assault, but does not require institutions to follow up in their reporting so outcome data is relatively non-existent (DeMatteo et al., 2015). Another systematic flaw with this legislation is that loopholes in regards to documenting the total number of campusrelated sexual assault cause massive discrepancies leaving data to suggest that far more sexual offenses are occurring than are depicted (Lombardi, 2009). One of the biggest loopholes universities have found is that assaults reported in confidence to mental-health or pastoral 
counselors do not have to be reported (Lombardi, 2009), which drastically decreases the number of incidents included in annual reports.

Originally, when schools were found to be in violation with the Clery Act, the Department of Education fined institutions $\$ 25,000$ per violation, then violations prior to November 3, 2015 were subject to $\$ 35,000$ fines, and now fines can hold a penalty of more than \$55,000 (Malafronte, 2018; Oehme et. al., 2015; Schroeder, 2014). For example, in 2007, LaSalle University was found to be incompliant with the act and was fined $\$ 110,000$. Although LaSalle was found guilty of not reporting 28 crimes, only some of which were sexual assaults, they appealed the decision and only ended up paying \$87,500 (Lombardi, 2010). Another large fine was handed down to Eastern Michigan University for failing to adequately address and publicize the rape and murder of a female student in her dorm room. Eastern Michigan University was found to be incompliant with Clery standards and justly fined $\$ 350,000$ (Lombardi, 2010; Schroeder, 2014). To date, however, the largest two fines handed down under the Clery Act were given to the Pennsylvania State University in 2016 and the University of Montana in 2018. The University of Montana was fined close to a million dollars (i.e., $\$ 966,614$ ) for reporting inaccurate and misleading crime statistics such as liquor store violations and rape cases from 2012-2015 (Malafronte, 2018); whereas Penn State was fined nearly \$2.4 million for failing to comply with the Clery Act over its handling of on-campus sex offenses and former football coach Jerry Sandusky (Staff, 2016). Although the University of Montana is in the process of appealing their fine, Penn State did not contest the Department of Education's findings and instead paid the fine in full (Thompson, 2016).

This is a national crisis that seems to have no end in sight and for that, officials have no other choice, but to drastically crack down on institutional reporting. Countervailing pressures to 
paint an institution's public image in a positive light, unfortunately, still loom over institutions leading to drastic underreporting of these crimes. Officials are even calling schools to investigate if they see one non-forcible sexual offense show up on their annual report (Lombardi, 2009) because these errors may not be accidents and may be motivated by institutions' interests in protecting their reputations.

Campus SaVE act Wanting to address the failures of the Clery Act and Title IX, the Department of Education signed into law new legislation that would better help to uncover the secrecy surrounding sexual assaults on college campuses (Sloan et al., 1997) by forcing colleges and universities to report accurate crime statistics. This legislation came in response to a report produced by the federal government in 2014 that described the nature of sex crimes on campuses across the country and the pervasive problem of underreporting (The White House, 2014). The Campus Sexual Violence Elimination (SaVE) Act officially became effective in March 2014 as part of the VAWA Reauthorization (Schroeder, 2014), which once again amended the Clery Act (Glass, 2013; Moylan, 2017). The overarching goal behind the SaVE Act is to address the flaws of previous sexual assault legislation by requiring schools to clearly explain their policies on sexual assault, stalking, domestic violence, and dating violence (Oehme et al., 2015; Schroeder, 2014). This act also requires that institutions expand their program offerings to more effectively promote awareness about these heinous crimes (Mancini et. al., 2016). These programs are too offer participants information regarding consent, different methods of effectively executing bystander intervention, and even information that would help participants pinpoint red flags in relationships early on before any type of physical violence would occur (Schroeder, 2014). And finally, the SaVE Act increases the level of transparency between the institution and the student, by informing the student in more detail of their rights in regards to reporting, legal action, or 
victim services (Glass, 2013; Schroeder, 2014). Whereas the now rescinded Dear Colleague Letter made mention of schools implementing educational programs such as those listed previously, the SaVE Act actually mandates that these institutions follow through (Schroeder, 2014).

Lindo, Marcotte, Palmer, \& Swensen (2018), found that when a school is under investigation for a Title IX violation, the number of females enrolling actually increases the year following the scandal. This number is even more significant two years out. On the flip side, undergraduate male enrollment is even more significantly impacted by an institution's Title IX investigation (Lindo et. al., 2018). More males were found to enroll at institutions the two years following a Title IX investigation as a direct result of an increased level of applicants in the years following a scandal. What these mixed results show is that to the extent that scandals serve as a deterrent, campuses may actually be perceived as less risky to applicants. These applicants may also view their odds of getting accepted greater if less students are willing to apply. Although this research is informative for college administrators, thus far this line of work lacks research directly addressing the relationship between crime and institutional spending, which is where this paper fits in.

Luca, Rooney, \& Smith (2016), however, found that college scandals, especially those with extensive media coverage lead to both decreases in the number of college applications received by an institution and a major decrease in college ranking. Luca et. al. (2016) divided scandals into four categories, including: sexual assaults, murders, cheating, and hazing. These authors gathered data via Google searches of media content from the years 2001-2013 for the top 100 national universities as measured by the U.S. News and World Report for 2015. Specifically, these authors found that in the year following a scandal, colleges receive $2 \%$ fewer applicants, 
with this number growing to $5 \%$ if a scandal was mentioned just once in the New York Times, and $8.8 \%$ if mentioned at least five times (Luca et. al., 2016). This study also found that negative media attention can drop 10 rankings in the U.S. News College Rankings. However, it was also noted that scandals, especially those with extensive media coverage, have the potential to deter future scandals from occurring because of the accountability system that is created for the university as part of the administrative response to the scandal (Luca et. al., 2016).

\section{Campus Response}

According to researchers, to combat such a pervasive problem, colleges and universities should be adapting the 2004 California Campus Blueprint to address sexual assault (Lichty, Campbell, \& Schuiteman, 2008). This Blueprint defines best practices in campus-based responses to sexual and relationship violence specifically detailing five minimum components for developing a successful campus response. As discussed in-depth below, the five components for the Blueprint are: (1) prevention strategies, (2) faculty and staff training, (3) campus policies, (4) campus protocols, and (5) victim services.

Prevention strategies With sexual violence remaining one of the most serious and complex problems on college campuses (DeGue, 2014), prevention programs have become very common in these settings. At the start, prevention programs were designed to change beliefs and attitudes assumed to increase the probability of men perpetrating a sexual crime and of women failing to take sufficient precaution (Sochting, Fairbrother, \& Koch, 2004). This was problematic for women as these strategies often times reinforced gender social norms for public behavior by expecting women to dress in a certain way and avoid certain campus locations late at night if they wanted to avoid being sexually assaulted (Day, 1994). Examples of strategies that have the 
potential to actually increase women's fear as opposed to prevent sexual assault (Day, 1994) include pamphlets, flyers, and presentations about safety tips.

Over the years, these programs have been expanded to include issues of alcohol and drug consumption (Abbey, 2002; Schwartz \& Nogrady, 1996), debunking rape myths (Choate, 2003), and prevalence of acquaintance sexual assault (Sampson, 2002). These traditional programs tend to be brief one-hour lectures focused on educating about the problem (Howard, 2015). Although these programs may be helpful, risk reduction programs alone are insufficient to end campus sexual assault (Gidycz, Orchowski, Probst, Edwards, Murphy, \& Tansill, 2015) because knowledge is important, but knowledge alone does not prevent people from perpetuating sexual violence.

Instead, community-based prevention efforts involving bystander (i.e., third-party) education are recommended by some scholars as the primary way to prevent sexual assault (Katz \& Moore, 2013). These programs operate by increasing women's sense of physical competence and encourage women to roam about campus freely without fear of being assaulted (Day, 1994). Examples of these types of programs include self-defense classes and block watch programs around campus. Stemming from this methodology, the Green Dot Intervention Program was developed by Dr. Dorothy Edwards (Coker, Cook-Craig, Williams, Fisher, Clear, Garcia, and Hegge, 2011) as a model that goes beyond current federal mandates designed to reduce belief in rape myths. Rape myths are generalized beliefs about victims, perpetrators, or sexual assault incidents that suggest that a sexual assault did not occur (Burt, 1980; Oehme et. al., 2015). It was Dr. Edwards' hope that Green Dot would increase preemptive self-reported active bystander behaviors and reduce dating and sexual violence on campuses (Coker et. al., 2011). Dr. Edwards wanted to teach students to understand the motivations and antecedents to sexual violence by 
helping them to appraise situations and identify potential risks for violence (Coker et. al., 2011). Understanding how perpetrators choose and target victims allows the bystander to assess the situation and decide the best course of action using safe active bystander behaviors. Another great example of community-based prevention would be for the campus to organize a "Take Back the Night" march. These marches challenge the attitude that outdoors is automatically off limits to women at night based off of gendered social norms that exist on campus (Day, 1994).

As schools mandate a deeper dive into preventing campus sexual assaults, they are emphasizing to institution's that bystander programs by themselves are not enough. Along with bystander programs campuses around the nation are currently enacting self-defense classes, educational speakers, marches and workshops (Castellano, 2015). As the number of prevention programs increases, so too does the underlying cost to universities. Not only does each individual class have a monetary value, but schools are becoming increasingly more constrained deciding who would be qualified to teach the new classes (e.g., faculty only, staff, graduate students) and which department would support them (Castellano, 2015).

Faculty and staff training As legislation mandates, all colleges and universities receiving federal funding are now required to staff a Title IX coordinator. However, in order for the work of the Title IX coordinator to be effective, everyone in the school must be trained (Castellano, 2015). Although sexual assault training for faculty and staff was said to have doubled on campuses from the 80 's to early 2000's (Karjane et. al., 2005), and we see these numbers growing even more since the recent rise of the \#MeToo movement (Chu, 2018), this data can be misconstrued. While schools have improved upon the number of training programs they offer, faculty and staff more often than not still leave the training feeling inadequately equipped to deal with sexual assault prevention (Branch, Hayes-Smith, \& Richard, 2011). This is 
a huge problem for schools because if all the work is left for the Title IX coordinator, rather than including all faculty and staff in this prevention effort, they are likely to be facing litigation for mishandling sexual assault cases. For example, in July 2014, the University of Connecticut settled a federal sexual assault lawsuit for $\$ 1.3$ million, one of the highest-ever reported sexual assault settlements (Castellano, 2015). The lawsuit, which was filed in 2013, claimed that several school officials failed to perform their duties as mandatory reporters of sexual violence, with some even being completely unaware of the schools policies surrounding sexual assault after failing to notify a victim that their alleged assailants expulsion had been overturned (EatonRobb, 2013).

Along with making sure everyone on campus is aware, one way colleges and universities can best avoid these six figure payouts is to pay for insurance to cover them (Castellano, 2015). If this does not seem feasible for an institution; however, there is another option. Colleges and universities can create new positions that house employees roles related to sexual violence, such as a task force, advocate, or prevention specialist (Karjane et. al., 2005). By sending out a positive institutional message of commitment to preventing and responding to sexual violence, it would be the hope that these positions could increase reporting and knowledge of sexual assault (Amar, Strout, Simpson, Cardiello, \& Beckford, 2014).

\section{Campus protocols and policies}

Unfortunately, adding new positions to a college or university's payroll is easier said than done as there seems to be a tension between existing resource constraints and adding "mouths to feed" (Lichty, Campbell, \& Schuiteman, 2008). This results in a balancing act between not endangering the resources supporting existing programs while still recognizing where new positions and programs are truly needed. Stuck between a rock and a hard place, one of the worst 
things a college or university could do would be to over utilize their current faculty and staff, which tends to be when corners are cut and litigation ensues.

Regrettably though, new Title IX offices or task forces come at a hefty price. For example, at the recommendation of their sexual assault task force, Penn State University houses a Title IX office which staffs: a Title IX coordinator, an investigator, a prevention and education coordinator, and a deputy coordinator for Penn State's commonwealth campuses (Castellano, 2015). Penn State is paying their Title IX coordinator approximately $\$ 80,000$ a year, with salaries for the whole staff easily costing the school a six figure value. Not to mention, campuses are being constrained as they decide where these new positions will be housed and if new infrastructure is needed.

As universities deal with this balancing act head on, the cost of accusations, formal charges and prevention measures is skyrocketing. Having a campus policy in place that clearly defines sexual assault and how these cases would be handled if reported not only reduces women's sense of fear around campus (Day, 1994), but also places campuses in a better position to stay compliant with federal mandates. Unfortunately, it has been noted that only $66 \%$ of colleges make their sexual assault policies publicly available (Krivoshey, Adkins, Hayes, Nemeth, \& Klein, 2013). Even more worrisome is that of the colleges who did make their assault policies public, only half included specific goals, such as a no tolerance policy (McMahon, 2008), missing an important opportunity to send a clear stance to the community (Sabina \& Ho, 2014).

Although it should be noted that there is no one-size fits all model when it comes to policy, universities should try to be all encompassing and engage as many stakeholders in their policy as possible (Richards \& Kafonek, 2016). Sexual violence does not discriminate and can be 
directed toward men, women, members of the LGBTQ community, cultural or religious minorities, and even persons with disabilities (McMahon, 2008). Having a policy in place is important because it provides an outline for the steps a student can take if assaulted (McMahon, 2008) or if the student contracts a detrimental health issue and needs to see a doctor (Vladutiu, Martin, \& Macy, 2011).

Along with a specific sexual assault campus policy, other policies that impact the reduction of sexual assault factors are also key. For example, in 2016, Lippy \& DeGue found evidence that the number of sexual assaults on campus drastically decreases when universities raise alcohol prices or decrease availability by limiting alcohol density, such as through alcohol bans. Similarly, Stotzer \& MacCartney (2016) found a higher number of reported sexual assaults on campuses where students legally allowed to possess alcohol were allowed to have alcohol on school property, such as in the dormitories.

Victim services Over the last few decades, as anti-crime laws have increased the level of scrutiny colleges and universities apply to sexual assault cases, it has become very apparent that sensitivity to victims' needs and preferences is crucial to generating appropriate responses to crime (Engle, 2014). Through this increased level of regulation, it has been determined that campus protocols can also be helpful in responding to survivors to ensure consistency in treatment, referrals, and services. The needs of sexual assault survivors are immense and include medical, legal, and psychological interventions. Medical needs include the detection of injuries, the provision of emergency contraception, and treatment for sexually transmitted diseases (Amar et al., 2014). Legal interventions include evidence collection, forensic evaluation and documentation, and the initiation of support services (Amar et al., 2014). And lastly, 
psychological interventions include crisis intervention and referral for advocacy services

(Campbell, Townsend, Long, Kinnison, Pulley, Adams, Wasco 2006; Decker \& Naugle, 2009).

Research has documented both the immediate health consequences stemming from injury and trauma as well as long-term threats to health and well-being of sexual assault victims (Fisher et. al., 2000; Rennison, 2002). This uninviting reality means that college students bear a significant "cost" of attending college, one that is one that is very serious and damaging to their psychological and/or physical well-being (Gidycz et. al., 2008). Unfortunately, even when survivors have access to psychological and health services on campus, they tend to go relatively unused (Nasta, Shah, Brahmanandam, Richman, Wittels, Allsworth, \& Boardman, 2005). In support of this, Krebs, Lindquist, Warner, Fisher, \& Martin (2007) found that off-campus health and counseling services are used far more frequently than on-campus services due to the fact that very few survivors report the assault to campus authorities (Fisher, Daigle, Cullen, \& Turner, 2003; Krebs et al., 2007; Lindquist, Barrick, Krebs, Crosby, Lockard, \& Sanders-Phillips, 2013). In support of these claims, Senator Claire McCaskill administered a national survey and found that over $90 \%$ of institutions had access to community based victim services, whereas only $43 \%$ had access to campus-based (U.S. Senate Subcommittee on Financial and Contracting Oversight, 2014). Research also shows that over the years sexual assault training for faculty and staff has more than doubled (Karjane, Fisher, \& Cullen, 2005), but this data is often times misleading. Whereas the percentage of institutions offering sexual assault training has indeed increased, faculty and staff often report they still feel underqualified to handle sexual assault reporting (Branch, Hayes-Smith, \& Richard, 2011). Along the same line, most universities fail to even mention available victim services on their website (Englander, McCoy, Sherman, 2016; 
Lund \& Thomas, 2015), leaving them incompliant with the basic requirements of federal law (Karjane et al., 2005).

Thus, even when campuses do have a variety of services in place, students often times don't even know about them (Hayes-Smith \& Levett, 2010). To address this, Taylor (2018) encourages schools to improve their campuses' physical and mental health services to boost disclosure of sexual assault, while also placing emphasis on the improvement of intersectional counseling to promote sexual assault prevention and reporting (Taylor, 2018).

According to the SaVE Act, victims of sexual assault should have access to report their case to a campus-wide Sexual Assault Response Team 24/7 (Engle, 2014). According to legal expert Dr. Cantalupo, this legislation is interpreted as mandating each college campus to be equipped with an adequately staffed victim services office. She described these offices as "one of the most effective ways of addressing the myriad challenges related to addressing peer sexual violence" (Cantalupo, 2011). Adding to the struggle, in a study conducted prior to 2011, only $30 \%$ of campuses surveyed were found to have a victim advocacy staff, of which only $20 \%$ had a formal women's center (Amar et al., 2014). In support of these findings, Senator McCaskill (U.S. Senate Subcommittee on Financial \& Contracting Oversight, 2014) found that $20 \%$ offered no training to faculty or staff, $30 \%$ offered no training to students, and $10 \%$ did not have an appointed Title IX Coordinator as required by federal law. As previously mentioned, when schools are found to be in violation of federal law they risk monetary fines or undesired attention from regulatory bodies (Moylan, 2017), both of which limit the institution's autonomy. Indirectly these institutions also risk negative media attention, a decreased enrollment number, and alienated donors (Moylan, 2017).

\section{Rising Costs at Institutions}


Although campus crime expenditures do raise an institution's bottom line, there are a number of other factors that can explain the rising costs at colleges and universities. First, the demand for higher education has risen dramatically over the last three decades, with everyone now wanting to go to college (Hoffower, 2018). Unfortunately, once demand goes up and nothing else changes, it is inevitable that prices will rise. Another explanation for the rising costs at colleges and universities is the fact that a majority of these prospective students are now favoring colleges that invest more in nonacademic functions, such as athletics, student services, or living quarters, over institutions that spend a majority of their budget on academics (Leslie \& Rhoades, 1995; Jaschik, 2013). The only time it has proven beneficial to invest more money in instruction and academic support (i.e., courses, libraries, museums, etc.) is at elite institutions (Jaschik, 2013). As second-tier institutions find themselves spending money on amenities such as personal health care, counseling, lazy rivers, or even climbing walls, they tend to find themselves in an "amenities arms race" because they are using these investments to hang onto students and move up in the rankings (Adams, 2017; Jaschik, 2013). The only problem is, with these services being added because of student needs and demand continuing to grow, once they are added, most institutions are very reluctant to take them away (Hoffower, 2018).

With the amount being invested into these non-academic amenities continuing to rise, schools are continuously being faced with the challenge of where to get the money. One way schools have come up with to fund these amenities is to raise tuition prices. Although these amenities are not funded by tuition, but rather students' fees, schools are using rising tuition to fund the cost of instruction, which remains the single largest expense for a college or institution (Adams, 2017). With institutions using upwards of 40 percent of this money to pay faculty salaries, this frees up more non-tuition based revenue to invest in student services. 
While few researchers have directly studied costs, this is an important aspect for higher education institutions to understand so administrators can make informed decisions on how best to make their institutions most cost effective (Cheslock, Ortagus, Umbricht, \& Wymore, 2016). With the revenue sources that sustain colleges and universities being so unstable, these decisions would be best informed by evaluating data over time and adjusting for any cost changes due to variance in sexual crime on campus. While some authors have taken similar approaches in their research, no study has yet to use this approach when discussing the financial implications of sexual assault.

For example, Lindo et. al. (2018) used a time series approach to measure the impacts of Title IX investigations on total full-time female enrollment, first year full-time enrollment, continuing and transfer enrollment, and full-time enrollment by age. To fully assess the impact on student enrollment, Lindo et. al. (2018) used leading and lagging indicators of Title IX investigations in their models, such as completion and graduation rates. These authors found that Title IX investigations increased enrollment both for female and male students, with these numbers increasing a few years after the investigation. Similarly, McClure and Marvin (2018) used a pooled regression model to examine existing research on administrative spending at 164 public research universities over a 9 year time span. Specifically, these authors were examining whether switching to research university in the Carnegie Classification system influences administrative costs. The results of this study showed that indeed shifting to a research university status had a significant, positive influence on administrative spending, but that this spending tended to dissipate as time passed (McClure \& Marvin, 2018).

By using a similar approach, and accounting for changes in spending due to crime that occurred the previous calendar year, this paper is going to use the cost revenue theoretical lens 
and the positional arms race lens to examine whether the advancement associated with a policy or program in regards to sexual assault prevention justifies the increased costs it creates.

\section{Theory}

According to the revenue theory of costs (Bowen, 1980), universities spend all the money they raise, but never truly raise enough to break the cycle because they are continuously searching for maximum excellence and prestige. As referenced by Martin and Gillen (2009), higher education institutions are "cookie monsters". These institutions seek out all of the resources they can and then devour them because prospective students never truly know the quality of education provided by an institution and have nothing more to rely on than the institution's reputation (Leslie, Slaughter, Taylor, \& Zhang, 2012; Martin \& Gillen, 2009). Public perception is that price is a prior indicator of quality (Martin \& Gillen, 2009), so reputation competition becomes a race to spend as much as possible per student.

As more schools enter the education landscape, each school has to work even harder to raise their level of prestige in order to attract the best quality students and faculty (Russell, 2017). With state funding continuously decreasing over the last several years, schools have to find ways to make money and one of the simplest ways of doing this is by increasing tuition. With school quality being hard to determine, an increased sticker price and expenditures signals increased prestige to students (Russell, 2017). This means that schools can increase their prestige by raising tuition and increasing expenditures-such as those used to raise awareness to sexual assault and prevent these types of scandals from occurring.

All colleges and universities that receive any federal funding are required by law to comply with Title IX (Sienkiewicz, 2018). In the case of sexual assault, this requires colleges to promptly stop discrimination, make changes to address it recurrence, and address the lingering 
effects (Sienkiewicz, 2018). In order to fulfill these requirements, institutions must therefore provide resources for sexual assault prevention. While colleges have a little flexibility to decide how best to address the issue of sexual assault, they are required by law to provide certain resources, such as a Title IX coordinator (Sienkiewicz, 2018). While some institutions do not provide more than the resources required by law, some institutions choose to provide resources in addition to those required.

For example, Title IX states that institutions must provide all students with equal access to education, regardless of race (Brodsky, 2014). When sexual assault occurs, this means providing such services as dorm room or class schedule changes so that victims can avoid their abusers, tutors, advocates, and/or counseling (Brodsky, 2014). But, past this, some institutions may choose to provide victims more, such as an advanced level of medical care that may go beyond the basic forensic exam. Institutions may provide victims services such as sexually transmitted disease (STD) testing, emergency contraception, or preventative medication (Sienkiewicz, 2018).

Many experienced faculty and administrators have expressed that the success of institutions lies in the vision and mission of colleges (Serio, 2018). Institutions have to plan for the future and invest the resources, whether financial or personnel, to make it happen. For example, although Title IX indicates that a Title IX coordinator is to be employed on all federally funded institutions, it does not specify the number of deputy coordinators to employ under this position. Institutions must take it upon themselves to ensure the number of survivor advocates and Title IX team members is adequate for their institutions student population size (Serio, 2018). Research shows that a ratio of one employee per each 7,500 students would equate to a caseload of 450 cases, which is consistent with national standards (Serio, 2018). 
In order to assess institutions' financial responses to incidences of sexual violence, I will be asking two research questions. Please refer to Figure 1. Specifically:

RQ1: Is there a positive association between the number of reported crimes and sexual assaults and institutions' subsequent spending on student services (i.e., counseling)?

RQ2: Is there a positive association between the number of reported campus crimes and sexual assault and institutions' subsequent spending on institutional support (i.e., compliance)?

Furthermore, it is important to assess whether these relationships were impacted with the passing of the Dear Colleague Letter in 2011. The growing number of sexual assaults on college campuses and the failure of colleges and universities to properly acknowledge the growing epidemic at the expense of their public image in the eyes of wealthy donors, led to the Obama administration introducing the Dear Colleague Letter on April 4, 2011. Sexual assault was one of the most pressing controversies at the time, so this letter essentially detailed sexual-harassment rules for institutions to follow (Carroll, Dahlgren, Grab, Hasbun, Hayes, \& Muntis, 2013).

The Dear Colleague letter has left institutions not only facing stricter response requirements in the wake of a scandal, but also a greater cost of compliance. This piece of legislation made institutions more aware of the importance of investing in sexual assault prevention and bringing awareness to it if they want to continue to attract the top faculty, staff, and students. In order to fulfill compliance requirements, institutions must provide resources for sexual assault prevention, such as Title IX coordinators who can help institutions place more 
attention on institutional responses to these sexual assault cases. Institutions are also facing higher investment cost into student services by adding additional services such advocates and counselors.

In order to assess the effect of the Dear Colleague Letter on an institution's response to sexual assault, I will be asking one research question. Specifically:

RQ3: Did the association between campus sexual assault and institutional spending change with the 2011 issuance of the Dear Colleague Letter on sexual assault response?

While hierarchy in education is nothing new, it has become far more important than in the past because the economic reward for elite educational credentials has jumped sharply in recent decades. In light of this growing importance placed upon an institution's "rank", universities are facing increased pressure to bid for the countless resources that facilitate the pursuit for high rank (Frank, 1999; Leslie \& Rhoades, 1995). This could include competition for top students and faculty, participation in intercollegiate athletics, or even new dorms built amongst other structures (Cheslock et. al., 2016). With institutions directing their energies and resources toward activities that will enhance their status, and away from instruction, institutions are finding themselves faced with increasing administrative costs, as new offices and assignments are added to support such revenue sources (Leslie \& Rhoades, 1995).

For example, over the last few decades as institutions continue to find themselves marred from sexual assault scandals, many institutions are choosing to be proactive, rather than reactive. Institutions across the country are starting to develop Title IX departments and committees specifically designated with the task of handling such cases (Castellano, 2015), advocacy staff 
(Campbell, 2006; Decker \& Naugle, 2009), and centers for counseling services dedicated to sexual assault survivors, just to name a few. Unfortunately, along with increased status quo, these new additions to college campuses are bringing with them an increased regulatory burden (Leslie $\&$ Rhoades, 1995). As the government continues to crack down and enforce Title IX regulations on campuses across the nation, institutions are finding themselves investing heavily in not only Title IX staff, but also law enforcement officers, legal counsel, and public relations staff.

These pressures have caused the market of higher education to become one of a positional arms race that has already proved to be extremely costly, with this cost likely to just continue to rise in the coming years. A school's position, relative to other schools, determines its success in attracting students and student quality, which is largely determined by size of its student subsidies (Winston, 2000). With rewards depending upon rank, if a school hopes to change its position, it must spend more or change less and find resources to support this change. What this central role of positional competition means, is that if the next school down in the hierarchy increases its subsidy a school will either have to make same kind of move or risk losing position (Winston, 2000). Therefore, institutions need to be genuinely concerned about how they respond to these crimes, or at least be perceived as being genuinely concerned by prospective students, parents, donors, and even legislators, or risk losing reputation and attractive students. One way to do this is to hire more compliance staff and counselors if a crime does occur.

Therefore, the timeliness and quality of an institution's response is going to set them apart from the competition. Although institutions have been hesitant in the past to share their truth concerning sexual assault because of the highly competitive environment in which they 
seek faculty and students, sharing is the first step in removing the stigma around campus sexual assault (Serio, 2018).

One way institution's can share, while still seeming more concerned than peer institutions is to increase one's own campus resources in response to a crime at a nearby institution or competing institution. For example, when Dartmouth College experienced a 14\% drop in student applicants following a student outcry over the schools handling of campus sexual assault (Castellano, 2015), one of the first things done by the campus committee on sexual misconduct was a review of best practices at peer institutions (Silverstein, 2018). By institutions adopting effective strategies from other universities and avoiding those that have been found to be ineffective (Serio, 2018), they are placing themselves in a better position to effectively mitigate the problem than if they chose not to collaborate with other institutions.

In order to assess an institution's knowledge of or influence from a local institution's or peer institution's sexual assault prevention investment, I will be asking two research questions. Specifically:

RQ4: Is there a positive association between spending on student services or institutional support at one institution and the crimes or spending decisions at local institutions?

RQ5: Is there a positive association between spending on student services or institutional support at one institution and the crimes or spending decisions at peer institutions? 
Chapter 3: Methodology 


\section{Data}

Throughout its history, violence against women research has been primarily quantitative in nature (Campbell \& Wasco, 2005). While this study follows in line with those that came before it, what it brings to the literature stream is the benefit of pooling complementary expertise from practitioners to serve as an advanced form of research that may help shed light on some very perplexing questions surrounding sexual assault financing.

Data for this survey was collected through two main sources, including the U.S. Department of Education Crime and Safety survey and the Integrated Postsecondary Education Data System (IPEDS). Data was collected over a ten-year period, 2006-2015, for a set of over 2,300 public and private four-year institutions and over 1,000 public and private two year institutions.

From the U.S. Department of Education Crime and Safety website data was extracted for sexual violence. This included sexual offenses for both forcible and non-forcible, rape, fondling, incest and statutory rape. Due to inconsistency in reporting categories over time, a summation of all six variables was used as a proxy for the variable campus sexual violence.

For the financial costs associated with each I utilized IPEDS to extract data on both student services (i.e., student activities, cultural events, student newspapers, career guidance, counseling, financial aid administration, and student records) and institutional support (i.e., general administration services, long-range planning, legal and fiscal operations, space management, employee personnel and records, and logistical services such as development and public relations). These institutional expenditures are relevant to study because when an institution faces backlash from a sexual assault scandal or OCR Title IX investigation, their 
initial response is typically to add compliance staff, counseling units for victims, legal counsel, or public relations staff (Castellano, 2015; Karjane et. al., 2015; Lichty et. al., 2008).

I also used these two data sets to compile a list of statistical controls to ensure my model had a high degree of validity. For controls I first chose to look at institutional revenue, with the assumption that schools would tend to spend more as they made more (Bowen, 1980). As institutions add new infrastructures and amenities to campus to compete for the best student pool, one would think that student tuition would in return go up to cover some of these costs. Next, I chose to look at changes in student enrollment, broken down by both race and gender. These are crucial controls because as mentioned previously sexual violence on college campuses does not discriminate and although female students tend to be the target of these crimes most often, other student populations are also at risk. Knowing that different types of institutions (i.e., four-year vs. two-year) attract starkly different student bodies, I chose to control for institution type as well. Research shows that four-year institutions have a higher reported crime rate than two-year institutions, whereas HBCUs have differing results with some authors reporting lower rates and some reporting higher (Center for Disease Control and Prevention; 2012; Coulter \& Rankin, 2017; Krebs et. al., 2011). Similarly, I also chose to control for geographical location in regards to the college campus. And lastly, I chose to control for peer institutions' crime and spending. As institutions compete for both funding and student enrollment, they will stop at nothing to keep their elite status and maintain face with their competitors, donors, and potential student clientele (Cheslock et. al., 2016). With that being said, the pressure to house the same sexual assault victim services and protocols has never been higher. If institutions want to avoid large lawsuit payouts, they will invest heavily in ensuring they offer the same amenities as their competitors keeping them compliant with federal mandates. 
According to the data, out of the roughly 3,300 institutions included in the sample across the nation, about 32 percent are public. As a national average, these institutions spend about $\$ 12,000,000$ per year on institutional support and about $\$ 7,000,000$ per year on student services and report roughly 3.3 incidents of sexual violence each year. These institutions enroll 1,102 male students and 1,464 female students on average per year. Broken down even further, every year institutions average 1,003 undergraduate male students vs. 488 graduate male students and 1,321 undergraduate female students vs. 697 female graduate students (for institutions that have some graduate students). Please refer to Tables 1 and 2 for a full break down of descriptive statistics.

\section{Research Method}

In order to analyze just how much campus sexual assault is costing institutions across the nation, I chose to conduct three separate regression analyses. To address my first research question, I will use regression to evaluate the amount spent on student services the year after a crime was reported, whereas for the second research question I looked at the amount spent on institutional support following a crime report. Specifically, the first research question is looking at the amount spent to improve the campus climate for students through investments in counseling services for victims and other student services.; whereas the second research question evaluates how much institutions spend after a crime is reported on things such as salary and benefits for legal counsel, the implementation of a Title IX task force, and the addition of fellow compliance staff. The third research question is aimed at identifying any difference in institutional spending before and after the introduction of the Dear Colleague Letter. The fourth and fifth research questions are looking at the amount spent to save institutional prestige and compete with other institutions of the same class or geographic location. In order to evaluate the 
full effect of the Dear Colleague Letter, this regression model will be evaluated using two separate samples. The first will include all sexual assaults that occurred before 2011 (up to 2010) and the second will include any crimes occurring after 2011 (2012 and later). The two regression coefficients will then be compared to see if there are differences before and after 2011.

Specifically, Stata was used to estimate multiple regression models of year-over-year changes in spending as a function of prior-year crime reports and other statistical controls. The regression coefficient on both spending variables wasinterpreted as the financial magnitude of an institution's response to a reported crime, controlling for institutional revenue, enrollment by race and gender, enrollment by degree type, institution type, peer institutions' crimes and spending, crimes at institutions in the same state, and spending at institutions in the same state. Specifically I use the following specification:

$$
\mathrm{Y}=\mathrm{aC}+\mathrm{bF}+\mathrm{cE}+\mathrm{dI}+\mathrm{e}
$$

In this specification, Y represents the dependent variable or next year's expenditures on student services or institutional support. $\mathrm{C}$ represents campus crime, including current year crime counts at institution, at institutions of the same types, and at institutions in the same state. Similarly, F represents financial variables (i.e., total expenses by type and state, past student services expenses, past institutional support expenses, and total revenue), E represents enrollment information (i.e., enrollment by race and gender including nonresident male and female, black male and female, American Indian male and female, Asian male and female, Hispanic male and female, and white male and female), and I represents institution information (i.e., institution level and institution control). In some of the models, I was replaced with an institution fixed effect that absorbs all institution characteristics that don't change over time, 
such as institutional level and control. Letters a, b, c, and d are vectors of regression coefficients, whereas e is representative of the error term.

\section{Survey Analysis}

In order to obtain supplemental data, I distributed a quantitative survey to institutions' Title IX Coordinators or Deputy Coordinators in order to more concisely pinpoint sexual assault financial details. Although all institutions participating in the federal financial aid program are tasked with having a mandatory Title IX coordinator, not all institutions fall in line with this federal regulation. If an institution did not provide the contact information for a Title IX informant, then the Director of Student Services was contacted instead. Knowing that the role of student affairs practitioners is based on their ability to balance a holistic education with the care of individuals and community safety (Landreman \& Williamsen, 2018) made it an easy choice when deciding who to list as a survey contact. These individuals are tasked with creating an environment that promotes equity, civility, respect, healthy sexuality, and positive relationships, while also providing education on difficult social issues, and removing barriers in order to allow students to thrive (Landreman \& Williamsen, 2018).

For every school listed as a part of my data set, a row in an Excel spreadsheet was created listing the institution's name, geographic location, contact person, their formal job title, their email address, and their cell phone. As a first step in creating the Excel spreadsheet, each individual institution's webpage was scanned for pertinent information.

In the spring of 2019, this survey was distributed using Qualtrics. This platform was chosen due to its ease of use and reputable history, but no analysis comes without limitations. Although Qualtrics simplifies the survey process considerably, by offering 17 different formats 
for asking questions (i.e., multiple choice, true/false, open-ended, etc.) and allows you to export data directly into analysis programs such as SAS or Stata, it unfortunately only allows you to track respondents' participation if they take the survey from the direct link sent via email.

Before the initial email was sent out through Qualtrics with the direct link to the survey, I obtained IRB approval for the study. Once this process was complete, I sent an initial contact letter alerting recipients about the study and asking for their participation along with the direct link to the survey. Two weeks later I sent a thank you/reminder email. This contact served two purposes. It allowed me to thank those who have completed the survey and participated in the study and also allowed me to politely remind those who had not participated. Two weeks later I had an auto-generated email resent through Qualtrics to all non-participants as one final effort to increase the survey response rate. It was also a possibility that institutions with high Internet security would view Qualtrics as spam and immediately send the survey to the spam folder before a participant even has a chance to view the email. Please refer to Figure 2 to review the participant cover letter and Figure 3 for a full list of survey questions.

In order to analyze my survey findings, I merged the survey data with IPEDS data by matching institutions on both control level and institutional level. I used Stata to look at both descriptive statistics (i.e., gender, race, age, institutional level, etc.) and t-tests for each individual question. These t-tests allowed me to analyze whether or not the majority of differences in responses between institution types was significant at $\mathrm{p}<.05$ for each question.

\section{Limitations}

While these results do hold a lot of weight, there is a major limitation in these findings. With the data sources chosen (U.S. Department of Education Crime and Safety and the 
Integrated Post-Secondary Education Data System (IPEDS)), only schools that participate in federal financial aid were included, as these are the only institutions that are required to publish annual crime reports under the Clery Act (Fisher et. al., 2000; Janosik \& Plummer, 2005; Moylan, 2017; Nicholson et. al., 1998; Sloan et. al., 1997). Although this does make for a pretty all-encompassing data set, the limitation itself comes from the wording of the Clery Act. This act specially mandates institutions to make publicly available all reports of crimes occurring "on campus", which is defined under the act as on school grounds or sometimes on property owned or controlled by the University (Clery Center, 2017). Unfortunately, most campus-related rapes are believed to take place off campus (Lombardi, 2010), so this limiting definition leaves a lot of assaults to go unreported. Even more worrisome is that most of these off-campus assaults still occur between students, but are rarely ever rectified.

The Clery Act also lays out specific categories which these schools must report their crimes under, but the lack of clarity in defining forcible vs. non-forcible sexual crimes leaves a lot of grey area in the reporting numbers. This lack of clarity is another limitation to this study as the Campus Crime and Safety website did not provide enough data to separate the categories out and instead had to be analyzed as a total summation. According to Yung (2015), even regulatory oversight doesn't help the pervasive problem of underreporting that exists with these types of crime. With this oversight being found effective only temporarily, it is important to account for this in my model, which is part of the rationale for looking at these numbers both before and after 2011.

Another limitation of this study stems from the crime stated in these reports perhaps being related to an institution's financial standing, rather than being randomly assigned, which could cause the effect sizes in this study to not be causal impact measures. For example, 
institutions that have more compliance or oversight staff might be able to process more allegations and report more crimes than institutions with less staff. For this reason, I tried to remove as much outside variation as I could by using statistical controls such as institutional revenue, enrollment by race and gender, enrollment by degree type, peer institutions crimes and spending, crimes at institutions in the same state, and spending at institutions in the same state.

One further limitation stemming from the data chosen for this analysis is that the expenditures, student services and institutional support, may also include things not related to crime response, which may cause the financial amount of each to go up or down for unrelated reasons. For example, under institutional support items such as Title IX compliance, legal counsel, audit and oversight functions are all included as part of this study, but items such as general administrative services and logistics services such as purchasing and printing are not. For student services, items such as counseling, student activities, and student organizations are included, but items such as admissions and intramural athletics are not. 
Chapter 4 


\section{Survey}

Initially I sent the survey to 1,767 colleges and universities and received 302 responses, which gave me a response rate of $17.1 \%$. After I merged the survey data with the IPEDS data by matching institutions on public or private control and two- or four-year degree level, I was left with a response rate of $19.5 \%$ for four-year institutions, $13.5 \%$ for two-year institutions, and $15.3 \%$ for technical schools. After further analysis of the data I decided to drop the responses from technical schools due to a low response number of 19. After these responses were dropped, my overall combined response rate for two- and four-year institutions was $16.1 \%$.

After examining the responses, I also decided to drop all answers that did not respond to questions 1 (“Age”), 2 (“Gender”), 4 (“"Ethnicity”), 5 (“My institution can best be described as...”), 6 ("Please indicate your institutions total enrollment as of school year 2018-2019...”), and 8 ("Did the amount your institution invest change with the passing of the Dear Colleague Letter in 2011?”). After the decision was made to exclude these responses, 18 were excluded dropping my sample to 284 viable responses or a useable response rate of $16.1 \%$.

\section{Descriptive Statistics}

Out of the respondent pool, 189 (66.55\% were from female respondents and $93(32.75 \%)$ from male respondents with the remaining two choosing not to disclose their gender. With respect to race and ethnicity, respondents were identified as American Indian or Alaska Native (n $=3,1.05 \%)$, Asian $(n=6,2.11 \%)$, Black or African American $(n=41,14.39 \%)$, Hispanic or Latino $(n=8,2.81 \%)$, Native Hawaiian or Pacific Islander $(n=4,1.40 \%)$, White $(n=212$, $74.39 \%)$, and Other $(\mathrm{n}=11,3.86 \%)$. While the most respondents fell between the ages of 50-59 $(n=91,32.16 \%)$, other respondents reported their age to be under $30(n=5,1.77 \%)$, between $30-39(n=57,20.14 \%), 40-49(n=81,28.62 \%)$, or $60+(n=49,17.31 \%)$. With respect to the 
institution worked for, respondents either worked for four-year institutions $(n=137,48.41 \%)$, two-year institutions $(n=125,44.17 \%)$, or technical schools $(n=21,0.74 \%)$. With a $48 \%$ fouryear respondent rate, compared to the $41 \%$ in Table 1 , it can be noted that four-year institutions are slightly over represented among respondents relative to the national sample.

\section{Coding}

The survey is made up of a mix of fixed response questions and open-ended. In order to summarize responses across the 284 responses, I created category codes for the open-ended questions by identifying the most common responses. The first question that was coded was Q10 ("Did the passing of the Dear Colleague Letter influence sexual assault responses on your campus in any other ways?"). After analyzing all of the responses, the following four categories were created: (1) institution revised policies, (2) institution added personnel, (3) institution added training, and (4) institution had some other response. Some of the items included in the first category (i.e., institution revised policies) include policy and procedural overhaul, and investigative process $\&$ standard of proof. In the second category (i.e., institution added personnel) items such as added Title IX office or team, hired more staff, added more personnel, and initiated Title IX Coordinator role were included. For the third category (i.e., institution added training) I included responses such as training modules, new trainings for staff and faculty, increased prevention training, increased training availability, and increased funding for trainings. And finally, for the fourth category (i.e., institution had another response), responses included mentioned items such as communication campaigns, more reports, defined responsible parties, new programming materials, and published information on website for student access. I ultimately chose to keep training and programming responses in two different categories because 
normally the training responses were geared more toward faculty and staff and programming more toward students and victims.

The second question coded was Q20 ("What victim services are provided by your institution? What kinds of resources do these strategies require [personnel, outside vendors, etc.]?”). The categories created for this question include: (1) institution offered counseling, (2) institution offered advocates, (3) institution offered external resources, and (4) institution had some other response. Some of the items included in category one (i.e., institution offered counseling) include on-campus counseling, mental health counselors, and counseling centers. For the second category (i.e., institution offered advocates) I included responses mentioning items such as campus/survivor/victim advocates, in-house/campus personnel, and health team/CARE team/wellness center. In the third category (i.e., institution offered external) items such as vendors, referral to community/outside agencies, local women's center, and third party counseling were included. And finally, for the fourth category (i.e., institution had other), responses included mentioned items such as ongoing training, staff time and planning, assistance with filing a police report, transportation assistance in medical care, and accommodations related to classes.

The third question coded was Q30 (“Are there other influences on your institution's approach to responding to incidents of sexual assault?"). The categories created for this question were: (1) institution follows federal mandates, (2) institution follows state rules, (3) institution responds to student needs, and (4) institution has other influence. Some of the items included in category one (i.e., institution follows federal mandates) include laws and regulations, case law, OCR directives, current administration, and Department of Education (DOE) requirements. For the second category (i.e., institution follows state rules) I included responses mentioning items 
such as state mandates rules and regulations, state laws, and circuit court decisions. In the third category (i.e., institution responds to students' needs) items such as local community pressures, best practices, policy response or on-campus police office, student safety, student needs, and student initiated programs were included. And finally, for the fourth category (i.e., institution has other influence) responses included mentioned items such as media/local news, social media, professional organizations, social justice, training, and union contracts.

The fourth and final question coded was Q31 (“Are there any constraints on your institution's approach to responding?"). After analyzing all responses, the categories created for this question were: (1) institution has resource constraints, (2) institution has staff constraints, and (3) institution has other constraints. Some of the items included in category one (i.e., institution has resource constraints) include budgetary constraints and community resources. For category two (i.e., institution has staff constraints) I included responses making note of items such as staff capacity and response time. And finally, for the third category (i.e., institution has other), responses included mentioned items such as buy in, direction/single clear mission and vision, college policies, conflicting state and federal laws, training, very low reporting levels, location and size of campus, and declining enrollment.

Once all four of these questions were coded, I then had to go through and assign each response to an appropriate category in a way that allowed for quantitative analysis. If a response fit with a category, it was coded with a 1 . If it did not fit into a category, it was coded with a 0 . It was possible for a single response to fit more than one or even all categories pertaining to a single question. After all responses were coded and categorized, each category was considered an individual variable for analysis.

\section{Results}


Institutions were asked whether or not the amount their institution invests in sexual assault prevention changed with the issuance of the Dear Colleague Letter in 2011. Among all respondents, $54.20 \%$ said yes, $13.74 \%$ said no, and $23.38 \%$ said maybe. Further, $68 \%$ of 4 -year institutions said yes and $50.44 \%$ of 2-year institutions said yes. A t-test suggests that the difference between two-year and four-year institutions in responding "Yes" to changing the amount their institution invested after the issuance of the Dear Colleague Letter is statistically significant at $\mathrm{p}=.0057$.

Furthermore, $71.58 \%$ of all respondents $(n=204)$ said their investments increased, while only $2.11 \%(n=6)$ said they decreased. Further, $99.08 \%$ of responding four-year institutions $(n=$ 108) said their investments increased and $95.51 \%$ of responding two-year institutions $(\mathrm{n}=85)$ said their investments increased. A t-test suggests that the difference between two-year and fouryear institutions in responding "Yes" to increasing their investment amount after the passing of the Dear Colleague Letter in 2011 is not statistically significant at $\mathrm{p}=.1092$.

Among other changes in campus sexual assault response beyond financial investments, $27.32 \%$ of respondents $(n=50)$ noted that they revised campus policies. About $33.66 \%$ of responding 4-year institutions $(n=34)$ and $19.75 \%$ of responding 2-year institutions $(n=16)$ noted some change in campus policies, and a t-test suggests the difference in response between two- and four-year institutions was statistically significant at $\mathrm{p}=.0368$.

In total, $28.42 \%$ of total institutions $(n=52)$ also noted that they added personnel. Personnel isn't just hiring more staff, but also includes bringing on more people internally from the college and designating new responsibilities to responsible parties. About $33.66 \%$ of responding four-year institutions $(\mathrm{n}=34)$ and $22.22 \%$ of responding two-year institutions $(\mathrm{n}=$ 18) noted some change in personnel, and a t-test suggests the difference between two-year and 
four-year institutions was not statistically significant at $\mathrm{p}=.0904$. In total, $25.14 \%$ of total institutions $(n=46)$ also noted that they added training. About $23.76 \%$ of responding four-year institutions $(n=24)$ and $27.16 \%$ of responding two-year institutions $(n=22)$ noted adding some training, and a t-test suggests the difference between two-year and four-year institutions was not statistically significant at $\mathrm{p}=.6025$. Further, $44.26 \%$ of total institutions $(n=81)$ also noted other responses than the main three previously mentioned. This category lumped miscellaneous items together that were important in terms of raising an institutions expenses, but perhaps were not acknowledged by many schools. About $45.54 \%$ of responding four-year institutions $(\mathrm{n}=46)$ and $41.98 \%$ of responding two-year institutions $(n=34)$ noted other responses, and a t-test suggests the difference between two-year and four-year institutions was not statistically significant at $\mathrm{p}=.6320$.

Respondents were next asked to identify what victim services their institution provided and what resources they are used to allow for these services. In total, $58.52 \%$ of total institutions $(n=103)$ noted that they offered counseling. About 57.29\% of responding four-year institutions $(n=55)$ and $59.49 \%$ of responding two-year institutions $(n=47)$ noted offering counseling, and a t-test suggests the difference between two-year and four-year institutions was not statistically significant at $p=.7704$. In total, $36.93 \%$ of total institutions $(n=65)$ noted that they offered advocates. About $52.08 \%$ of responding four-year institutions $(n=50)$ and $18.99 \%$ of responding two-year institutions $(n=15)$ noted offering advocates, and a t-test suggests the difference between two-year and four-year institutions was statistically significant at $\mathrm{p}=.0000$. In total, $59.66 \%$ of total institutions $(n=105)$ noted that they offered external services. About $46.88 \%$ of responding four-year institutions $(n=45)$ and $74.68 \%$ of responding two-year 
institutions $(n=59)$ noted offering advocates, and a t-test suggests the difference between twoyear and four-year institutions was statistically significant at $\mathrm{p}=.0002$.

While the majority of responses were captured in the first three categories, a few institutions did mention offering other services, such as sexual assault resource centers or domestic violence shelters. In total, $32.39 \%$ of total institutions $(n=57)$ noted that they offered other services. About $36.46 \%$ of responding four-year institutions $(n=35)$ and $27.85 \%$ of responding two-year institutions $(n=22)$ noted offering other services, and a t-test suggests the difference between two-year and four-year institutions was not statistically significant at $\mathrm{p}=$ .2288 .

I also asked respondents if there were other influences on their institutional approach to responding to incidents of sexual assault. While respondents mentioned a variety of influences, the three main themes were federal mandates, state rules, and student needs. In total, $31.34 \%$ of total institutions $(n=42)$ noted that they follow federal mandates. About $33.85 \%$ of responding four-year institutions $(\mathrm{n}=22)$ and $29.41 \%$ of responding two-year institutions $(\mathrm{n}=20)$ noted following federal mandates, and a t-test suggests the difference between two-year and four-year institutions was not statistically significant at $\mathrm{p}=.5857$.

In total, $25.37 \%$ of total institutions $(n=34)$ noted that they follow state rules. About $26.15 \%$ of responding four-year institutions $(n=17)$ and $25.00 \%$ of responding two-year institutions $(\mathrm{n}=17)$ noted following state rules, and a t-test suggests the difference between twoyear and four-year institutions was not statistically significant at $p=.8799$. In total, $29.10 \%$ of total institutions $(n=39)$ noted that they were influenced by student programs. About $38.46 \%$ of responding four-year institutions $(\mathrm{n}=25)$ and $20.59 \%$ of responding two-year institutions $(\mathrm{n}=$ 14) noted offering student programs, and a t-test suggests the difference between two-year and 
four-year institutions was statistically significant at $\mathrm{p}=.0236$. In total, $23.88 \%$ of total institutions $(n=32)$ noted that they had other influences. About $20.00 \%$ of responding four-year institutions $(n=13)$ and $26.47 \%$ of responding two-year institutions $(n=18)$ noted offering other staff, and a t-test suggests the difference between two-year and four-year institutions was not statistically significant at $\mathrm{p}=.3815$.

While both two- and four-year institutions are able to offer a variety of services in regards to sexual assault prevention, there are some constraints that impact how an institution wishes to respond. The first constraint, identified as resource constraints, ultimately impacts what services institutions are able to offer and whether or not they are offered on-campus or off. In total, $30.07 \%$ of total institutions $(n=43)$ noted that they suffer from resource constraints. About $31.51 \%$ of responding four-year institutions $(n=23)$ and $28.99 \%$ of responding two-year institutions $(\mathrm{n}=20)$ noted suffering from resource constraints, and a t-test suggests the difference between two-year and four-year institutions was not statistically significant at $\mathrm{p}=.7459$. In total, $24.48 \%$ of total institutions $(n=35)$ noted that staff constraints impact their institution. About $24.66 \%$ of responding four-year institutions $(n=18)$ and $24.64 \%$ of responding two-year institutions $(\mathrm{n}=17)$ noted staff constraints impacting their institution, and a t-test suggests the difference between two-year and four-year institutions was not statistically significant at $\mathrm{p}=$ .9978 . In total, $16.78 \%$ of total institutions $(n=24)$ noted that other constraints impact their institution. About $17.81 \%$ of responding four-year institutions $(n=13)$ and $14.49 \%$ of responding two-year institutions $(n=10)$ noted other constraints impacting their institution, and a t-test suggests the difference between two-year and four-year institutions was not statistically significant at $\mathrm{p}=.5951$. 
Institutions were asked whether they are aware of how much institutions within the same state are spending on sexual assault prevention. Among all respondents, $1.52 \%$ said yes $(n=4)$, $63.64 \%$ said no $(n=168)$, and $1.89 \%$ said maybe $(n=5)$. Further, $2.06 \%$ of four-year institutions $(n=2)$ said yes and $2.53 \%$ of two-year institutions $(n=2)$ said yes. A t-test suggests that the difference between two-year and four-year institutions in responding "Yes" to acknowledging the amount spent by same state institutions is not statistically significant at $\mathrm{p}=.8364$.

Institutions were asked whether the amount spent by same state institutions influences the amount their institution invests. Among all respondents, $1.14 \%$ said yes $(n=3), 66.86 \%$ said no $(n=113)$, and $20.08 \%$ said maybe $(n=53)$. Further, $2.22 \%$ of four-year institutions $(n=2)$ said yes and $1.28 \%$ of two-year institutions $(n=1)$ said yes. A t-test suggests that the difference between two-year and four-year institutions in responding "Yes" to allowing the amount spent by same state institutions to influence the amount their institutions invests in sexual assault prevention is not statistically significant at $\mathrm{p}=.6487$.

Institutions were asked whether they were aware of peer group spending on sexual assault prevention. Among all respondents, $1.52 \%$ said yes $(n=4), 61.36 \%$ said no $(n=162)$, and $2.65 \%$ said maybe $(n=7)$. Further, $3.19 \%$ of four-year institutions $(n=3)$ said yes and $1.28 \%$ of two-year institutions $(n=1)$ said yes. A t-test suggests that the difference between two-year and four-year institutions in responding "Yes" to being aware of peer group spending is not statistically significant at $\mathrm{p}=.4111$. Institutions were asked whether the amount spent by peer institutions influences the amount their institution invests. Among all respondents, $2.65 \%$ said yes $(n=7), 45.83 \%$ said no $(n=121)$, and $16.67 \%$ said maybe $(n=44)$. Further, $4.30 \%$ of fouryear institutions $(n=4)$ said yes and $3.85 \%$ of two-year institutions $(n=3)$ said yes. A t-test suggests that the difference between two-year and four-year institutions in responding "Yes" to 
allowing the amount spent by peer group institutions to influence the amount their institutions invests in sexual assault prevention is not statistically significant at $\mathrm{p}=.8820$

\section{Regression}

\section{Main Findings}

Table 3 illustrates results from regressions of student services expenditure on prior-year crime reports, total revenues and expenditures, enrollment levels by race and gender, and indications for four-year degree record, public control, and HCU status. Similarly, Table 4 illustrates results from regressions of institutional support expenditures on prior-year crime reports, total revenues and expenditures, enrollment levels by race and gender, and indications for four-year degree record, public control, and HBCU status. Columns one \& two in both Table $3 \& 4$ reflect results for all institutions, columns three and four reflect private four-year student service expenses, columns five and six include public four-year student service expenses, and columns seven and eight reflect public two-year student service expenses. Within each pair of columns, the first column includes the predictor variable only, and the second column includes the predictor variables only, and the second column adds institution fixed effects because a higher number of crimes may reflect more than just increased reporting numbers.

Specifically, in column one Table 3, schools are investing \$490,251 more in student services the following year. When fixed effects are added to try and eliminate any bias (i.e., a higher number of crimes may reflect more than just crimes such as if a school is more honest and thus reports more or has more staff dedicated to reporting and compliance) schools are still shown to be investing $\$ 87,153$ per previous year sexual assault.

When comparing across institution type, it was found that private four-year institutions invest the most into student services after a reported sexual crime. Specifically, private four-year 
institutions are investing $\$ 618,664$ per reported crime, compared to public four-year institutions who invest $\$ 343,115$ and public two-year who invest $\$ 38,239$. While all of these investments are significant according the regression model, I still wanted to try and eliminate any bias so ran the regression again with fixed effects. With the fixed effects added, it was found that private fouryear institutions invest $\$ 122,316$ per reported assault, while public four-year institutions invest $\$ 32,009$ and public two-year institutions invest $\$ 29,584$.

Looking now at institutional support expenses, as referenced in Table 4, for every on campus sexual assault reported the previous year, schools are investing $\$ 403,956$ more in institutional support the following year. When fixed effects are added to try and eliminate any bias, schools are still shown to be investing $\$ 64,727$ per previous year sexual assault.

When comparing across institution type, it was found that once again private four-year institutions invest the most into institutional support after a reported sexual crime. Specifically, private four-year institutions are investing $\$ 641,282$ per reported crime, compared to public fouryear institutions who invest $\$ 144,758$ and public two-year who invest $\$ 25,892$. Although it is worth noting that the amount public two-year institutions invest in institutional support is not significant. While the amounts invested by both private and public four-year institutions were both significant, I still wanted to try and eliminate any bias so ran the regression again with fixed effects. With the fixed effects added, it was found that private four-year institutions invest $\$ 112,364$ per reported assault, while public four-year institutions invest $\$ 11,509$ and public twoyear institutions invest $\$ 9,177$. The fixed effects not only reduced the total amount invested by each institutional type, but the amounts invested by public four-year institutions and public twoyear institutions were no longer significant in the fixed effects models.

Spending Before and After 2011 
The data was broken down even further to assess whether or not there was a relationship between the Dear Colleague Letter and institutional spending for sexual assault. The Dear Colleague Letter was chosen because it not only effectuated a presumption that all accused students are guilty (Henrick, 2013), but it also lowered the burden of proof in campus sexual assault trials to the lowest possible standard of proof, required schools to accelerate their adjudications, and eliminated cross-examination of accusers (Johnson \& Taylor, 2017). Essentially, this pivotal piece of legislation was the most influential in regards to sexual assault to date.

Table 5 illustrates results from regressions of both student service expenditures and institutional support on prior-year crime reports, total revenues and expenditures, enrollment levels by race and gender, and indications for four-year degree record, public control, and HCU status before and after 2011. Columns one \& two in Table 5 reflect results for all institutions, columns three and four reflect private four-year student service expenses, columns five and six include public four-year student service expenses, and columns seven and eight reflect public two-year student service expenses. Within each pair of columns, the first column includes the predictor variable only, and the second column includes the predictor variables only, and the second column adds institution fixed effects because a higher number of crimes may reflect more than just increased reporting numbers.

Results show that before the issuance of the Dear Colleague Letter in 2011, institutions were spending $\$ 410,943$ in student service expenses and $\$ 447,931$ in institutional support expenditures for every previous year reported campus sexual assault. To try and eliminate as much bias as possible, I reran the regression using fixed effects and found that institutions were actually investing $\$ 11,032$ less on student services the year following a reported sexual assault 
and \$18,262 more on institutional support. As referenced in Table 5, after the issuance of the DCL in 2011, institutions spending for both of these areas dropped considerably to $\$ 302,128$ and $\$ 224,354$, respectively. Although the investment amount per reported sexual crime did indeed decrease, the overall amount spent in both areas stayed significant as the total reported number of crimes increased. After the regression was rerun using fixed effects, it was found that institutions are investing $\$ 19,410$ in student services and actually decreased their spending in institutional support by $\$ 1,035$. Although it is noteworthy that spending in institutional support the year following a reported campus assault dropped so significantly after the passing of the DCL in 2011, the amount found to be invested using the fixed effects was not significant.

\section{Competition}

Table 6 illustrates results from regressions of student services expenditure on prior-year crime reports, total revenues and expenditures, enrollment levels by race and gender, and indications for four-year degree record, public control, and HCU status when comparing institutions from the same state or institutions of the same type. Columns one \& two in Table 6 reflect results for all institutions, columns three and four reflect private four-year student service expenses, columns five and six include public four-year student service expenses, and columns seven and eight reflect public two-year student service expenses. Within each pair of columns, the first column includes the predictor variable only, and the second column includes the predictor variables only, and the second column adds institution fixed effects because a higher number of crimes may reflect more than just increased reporting numbers.

Specifically, in column one Table 6, schools are investing $\$ 549,616$ more into their own sexual assault prevention measures the following year when institutions of the same type invest money. When fixed effects are added to try and eliminate any bias, these institutions are still shown to be investing $\$ 279,392$ per previous year sexual assault when institutions of the same 
type increase their own investment measures. When compared to institutions within the same state, schools are investing $\$ 266,692$ more the year following a sexual assault report. However, when fixed effects are added to try and eliminate any bias, these institutions are shown to be investing a non-significant amount less each time a sexual assault is reported. Specifically, schools are shown to decrease their investment amount by $\$ 3,321$ per reported assault. It is important to compare these two regression types to allow for time-invariant cofounders and see is these impact the results.

When comparing across institution type, it was found that when compared to institutions of the same type, public four-year institutions invest the most into student services after a reported sexual crime. Specifically, public four-year institutions are investing $\$ 619,582$ per reported crime, compared to private four-year institutions who invest $\$ 280,458$ and public twoyear who invest $\$ 135,241$ less per reported crime. While all of these investments are significant except for the amount invested by public two-year institutions according to the regression model, I still ran the regression with fixed effects to try and eliminate any bias. With the fixed effects added, it was found that public four-year institutions invest $\$ 168,669$ per reported assault, while private four-year institutions invest $\$ 318,611$ and public two-year institutions invest $\$ 133,529$.

When comparing institutions within the same state, it was found that when compared to institutions from the same geographic area, private four-year institutions invest the most into student services after a reported sexual crime. Specifically, private four-year institutions are investing $\$ 257,613$ per reported crime, compared to public four-year institutions who invest $\$ 243,904$ and public two-year who invest $\$ 100,758$ per reported crime. While all of these investments are significant according to the regression model, I still ran the regression with fixed effects to try and eliminate any bias. With the fixed effects added, it was found that across all 
three types of institutions, investments into sexual assault prevention became a negative amount. Specifically, private four-year institutions are shown to invest $\$ 56,015$ less per reported assault, while public four-year institutions invest $\$ 118,007$ less per reported assault and public two-year institutions invest $\$ 41,093$ less. It is also important to note that when fixed effects were added, the amount invested by private four-year institutions became non-significant.

Looking now at institutional support, as referenced in Table 7, for every on campus sexual assault reported the previous year, schools are investing $\$ 71,478$ less when compared with institutions of the same type. With this number not significant according to the regression, the regression was rerun using fixed effects to try and eliminate any bias. With fixed effects included, schools are shown to invest $\$ 109,205$ more into institutional support expenses per reported sexual assault when compared to institutions of the same type. When compared to institutions within the same state, schools are investing \$256,234 more the year following a sexual assault report. When fixed effects are added to try and eliminate any bias, schools are shown to increase their investment amount by $\$ 28,543$ per reported assault. Unfortunately, this amount it not significant according to the regression.

When comparing across institutional type, it was found that public four-year institutions invest the most into institutional support after a reported sexual crime. Specifically, public fouryear institutions are investing $\$ 208,762$ per reported crime, compared to private four-year institutions that decrease their investment by $\$ 337,328$ and public two-year institutions that invest $\$ 35,546$ more per reported crime. While all of these investments are significant according to the regression model, except for the amount invested by two-year institutions, I still ran the regression with fixed effects to try and eliminate any bias. With the fixed effects added, it was found that public four-year institutions invest $\$ 144,368$ per reported assault, while private four- 
year institutions invest $\$ 40,189$ less per reported assault and public two-year institutions invest $\$ 193,486$ more. It is also important to note that when fixed effects were added, the amount invested by private four-year institutions became non-significant, with the investment amount for two-year institutions staying non-significant.

When comparing institutions within the same state, it was found that public four-year institutions invest the most into institutional support after a reported sexual crime. Specifically, public four-year institutions are investing $\$ 807,964$ per reported crime, compared to private fouryear institutions who invest $\$ 20,599$ less per reported assault and public two-year who invest $\$ 89,083$ more per reported crime. While all of these investments are significant according to the regression model, except for the amount invested by two-year institutions, I still ran the regression with fixed effects to try and eliminate any bias. With the fixed effects added, it was found that only the investment amount for public four-year institutions is significant. Specifically, public four-year institutions are shown to invest $\$ 261,575$ per reported assault, while private four-year institutions invest \$71,349 less per reported assault and public two-year institutions invest $\$ 29,442$ less.

Table 8 illustrates results from regressions of both student service expenditures and institutional support expenditures on prior-year crime reports, total revenues and expenditures, enrollment levels by race and gender, and indications for four-year degree record, public control, and HCU status when comparing institutions from the same state or institutions of the same type. Columns one \& two in Table 8 reflect results for all institutions, columns three and four reflect private four-year student service expenses, columns five and six include public four-year student service expenses, and columns seven and eight reflect public two-year student service expenses. Within each pair of columns, the first column includes the predictor variable only, and the 
second column includes the predictor variables only, and the second column adds institution fixed effects because a higher number of crimes may reflect more than just increased reporting numbers.

Results show that before the issuance of the Dear Colleague Letter in 2011, institutions were spending $\$ 1,905,000$ more in student service expenses and $\$ 1,960,000$ more in institutional support when institutions of the same type were investing more in their sexual assault prevention measures. When the fixed effects were added to the regression, it was found that institutions were actually spending $\$ 167,982$ less in student services anytime an institution of the same type increased their own sexual assault prevention measures, and \$461,982 less in institutional support. Although, it is important to note that the amount invested for student services once fixed effects were added is not significant.

When compared across institutions within the same state, institutions were found to be investing $\$ 673,668$ more in student services and $\$ 759,839$ more in institutional support when institutions from within the same state invested more into their sexual assault prevention measures. Once the fixed effects were added and the regression was rerun, it was found that the investment amount per reported sexual crime did indeed decrease when compared to other institutions within the same state and both amounts became non-significant. Specifically, institutions were found to be investing $\$ 110,982$ in student services and $\$ 116,069$ in institutional support.

As referenced in Table 8, after the issuance of the Dear Colleague Letter in 2011, institutions spending for both of these areas dropped considerably to $\$ 549,291$ and $\$ 274,827$, per reported crime, when institutions of the same type were investing more in their sexual assault prevention measures. After the regression was rerun using fixed effects, it was found that 
institutions are investing $\$ 232,010$ more in student services and $\$ 68,823$ more in institutional support. It is important to note that the amount invested in institutional support once fixed effects were added is not significant.

When comparing across institutions within the same state, institutions were found to be investing $\$ 269,102$ more in student services and $\$ 248,767$ more in institutional support when institutions from within the same state invested more into their sexual assault prevention measures. Although the investment amount per reported sexual crime decreased, the overall amount spent in both areas stayed significant as the total number of crimes increased. After the regression was rerun using fixed effects, it was found that institutions are investing $\$ 165,715$ in student services and \$160,486 in institutional support.

\section{Other Predictors}

\section{Student Services}

It is also important to note that when looking at all institutional types together in regards to student service expenditures, as referenced in Table 3, American Indian/Alaskan Native female enrollment and Asian male enrollment were also found to be significant before fixed effects were added, and then not when the effects were added. And then opposite of this, black male enrollment, Hispanic male enrollment, and white male enrollment were not significant before the fixed effects were added, but once the effects were added they all became significant.

Furthermore, across all three institution types, before fixed effects were added, total revenue was found to be significant, but once the fixed effects were added all three institutional types found their revenues to be non-significant. Something else that changed across all three institution types with the addition of the fixed effects was black female enrollment. Black female 
enrollment across all three was originally not significant, but then once the effects were added this relationship changed to significant across the board.

Through the addition of the fixed effects, private four-year institutions saw some notable changes in relationships with nonresident male enrollment and American Indian/Alaska Native female enrollment, which both changed from significant to not significant. Also, both Asian male enrollment and Hispanic female enrollment changed from not significant to significant. Similarly for public four-year, nonresident female enrollment, black male enrollment, and Asian female enrollment changed from not significant to significant with the addition of the fixed effects, while American Indian/Alaska Native female enrollment changed from significant to not significant. And finally, for public two-year institutions we saw the relationship for black male enrollment change from not significant to significant. Please reference Table 3 for a full break down of regression results.

\section{Institutional Support}

In regards to institutional support expenditures, as referenced in Table 4, it is also important to note that when looking at all institutional types together, Asian male enrollment, Hispanic female enrollment, and white male enrollment were also found to be significant before fixed effects were added, and then not when the effects were added. And then opposite of this, white female enrollment were not significant before the fixed effects were added, but once the effects were added they all became significant.

Furthermore through the addition of the fixed effects, private four-year institutions saw some notable changes in relationships occur with American Indian/Alaska Native female enrollment and Hispanic female, which both changed from significant to not significant. Also, nonresident female enrollment changed from not significant to significant. Similarly for public 
four-year, Hispanic male changed from not significant to significant with the addition of the fixed effects, while total revenues, black male enrollment, American Indian/Alaska Native male enrollment, Hispanic female enrollment, and white female enrollment all changed from significant to not significant. And finally, for public two-year institutions we saw the relationship for Hispanic female enrollment change from not significant to significant, while the relationships for nonresident male enrollment, Asian female enrollment, and white male enrollment changed from significant to not significant. Please reference Table 4 for a full break down of regression results.

Before \& After 2011

In regards to student service investments before 2011, before fixed effects were added, black male enrollment and Asian female enrollment were found to be significant, but once the fixed effects were added both became non-significant. Also, American Indian/Alaska Native male enrollment, Hispanic male enrollment, Hispanic female enrollment, white male enrollment, and white female enrollment changed from not significant to significant. In regards to institutional support before 2011, before fixed effects were added, nonresident male enrollment, Asian male enrollment, and white male enrollment were found to be significant, but once the fixed effects were added both became non-significant. Also, black female enrollment and Hispanic male enrollment changed from not significant to significant.

When looking at student services after the issuance of the DCL in 2011, nonresident male enrollment, black female enrollment, American Indian/Alaska Native female enrollment, and Asian male enrollment were found to be significant, but once the fixed effects were added both became non-significant. Also, black male enrollment changed from not significant to significant. In regards to institutional support after 2011, before fixed effects were added, total revenue, 
black female enrollment, and Hispanic female enrollment were found to be significant, but once the fixed effects were added all three became non-significant. A fixed effects model is purely within institution, while OLS is both within and between which could explain why some of these demographic variables became insignificant when looking at the fixed effects model. Also, nonresident male enrollment, American Indian/Alaska Native female enrollment, white male enrollment, and white female enrollment changed from not significant to significant. Please refer to Table 5 for a full break down of regression results.

\section{Competition}

It is also important to note that when looking at all institutional types together in regards to student service expenditures, as referenced in Table 6, American Indian/Alaskan Native female enrollment was found to be significant before fixed effects were added, and then not when they were. And then opposite of this, Hispanic male enrollment and white male enrollment were not significant before the fixed effects were added, but then once the effects were added they both became significant.

Through the addition of the fixed effects, private four-year institutions saw some notable changes in relationships with black female enrollment and Asian male enrollment, which both changed from not significant to significant. Also, both American Indian/Alaskan Native female enrollment and Asian female enrollment changed from significant to not significant. Similarly, for public four-year, nonresident male enrollment, black male enrollment, Asian female enrollment, and white female enrollment changed from not significant to significant with the addition of the fixed effects, while black female enrollment and American Indian/Alaskan Native male enrollment changed from significant to not significant. And finally, for public two-year institutions we saw the relationship for Hispanic female enrollment change from not significant 
to significant. Interestingly, the relationships for black female enrollment, black male enrollment, American Indian/Alaskan Native male enrollment, American Indian/Alaskan Native female enrollment, white male enrollment, and white female enrollment stayed non-significant regardless if the fixed effects were included in the regression or not. Please reference Table 6 for a full break down of regression results.

In regards to institutional support expenditures, as referenced in Table 7, it is also important to note that when looking at all institutional types together, Asian male enrollment, Hispanic female enrollment, and white male enrollment were also found to be significant before fixed effects were added, and then not when the effects were added. And then again there were some relationships that were non-significant regardless if fixed effects were used or not. Specifically, these relationships were American Indian/Alaskan Native male enrollment and Asian male enrollment.

Furthermore, through the addition of fixed effects, private four-year institutions saw some notable changes in relationships occur with American Indian/Alaskan Native female enrollment and Hispanic female enrollment, which both changed from significant to not significant. Also, nonresident female enrollment changed from not significant to significant and white female enrollment was non-significant regardless if the fixed effects were included or not. Similarly for public four-year, black male enrollment and American Indian/Alaskan Native male enrollment changed from significant to not significant, while black female enrollment changed from not significant to significant. The relationship for both Asian male enrollment and Asian female enrollment stayed non-significant regardless if the fixed effects were used. And finally, for public two-year institutions, the relationship for black ale enrollment changed from not significant to significant, while the relationships for nonresident male enrollment, Asian female 
enrollment, and white male enrollment changed from significant to not significant. The relationships for black female enrollment, American Indian/Alaskan Native male enrollment, American Indian/Alaskan Native female enrollment, Hispanic Male enrollment, and Hispanic female enrollment were also all not significant regardless if the fixed effects were added. Please refer to Table 7 for a full break down of regression results.

In regards to student service investments before 2011, before fixed effects were added, black male enrollment and Asian female enrollment were found to be significant, but once the fixed effects were added both became non-significant. Also, American Indian/Alaska Native male enrollment, Hispanic male enrollment, Hispanic female enrollment, white male enrollment, and white female enrollment changed from not significant to significant. The relationships for both black female enrollment and American Indian/Alaskan Native female enrollment were not significant regardless if the fixed effects were added. In regards to institutional support before 2011, before fixed effects were added, nonresident male enrollment, Asian male enrollment, and white male enrollment were found to be significant, but once the fixed effects were added both became non-significant. Also, black female enrollment and Hispanic male enrollment changed from not significant to significant. The relationships for American Indian/Alaskan Native male enrollment, American Indian/Alaskan Native female enrollment, Hispanic female enrollment, and white female enrollment were not significant regardless if the fixed effects were added. When looking at student services after the issuance of the Dear Colleague Letter, nonresident male enrollment, black female enrollment, American Indian/Alaska Native female enrollment, and Asian male enrollment were found to be significant, but once the fixed effects were added both became non-significant. Also, black male enrollment and white male enrollment changed from not significant to significant. Both of the relationships for Hispanic male enrollment and 
American Indian/Alaskan Native male enrollment were not significant regardless if the fixed effects were added. In regards to institutional support after 2011, before fixed effects were added, total revenue, black male enrollment, and Hispanic female enrollment were found to be significant, but once the fixed effects were added all three became non-significant. Also, nonresident male enrollment, American Indian/Alaska Native female enrollment, white male enrollment, and white female enrollment changed from not significant to significant. The relationship for American Indian/Alaskan Native male enrollment was non-significant regardless if the fixed effects were added. Please refer to Table 8 for a full break down of regression results. 
Chapter 5: Conclusion 
The purpose of this quantitative study was to look at whether incidences of sexual violence on campus are associated with increased costs in policies and programs geared toward prevention of these incidents. This chapter includes a discussion of major findings as related to the literature on campus sexual assault prevalence and contributing factors, under reporting, and sexual assault policy and legislation including Title IX, the Clery Act, and the Dear Colleague Letter. The chapter concludes with a discussion of the limitations of the study, areas for future research, implications for practitioners, implications for policy, and a brief summary.

This chapter contains discussion and future research possibilities to help answer the research questions:

RQ1: Is there a positive association between the number of reported crimes and sexual assaults and institutions' subsequent spending on student services (e.g., counseling)?

RQ2: Is there a positive association between the number of reported campus crimes and sexual assault and institutions' subsequent spending on institutional support (e.g., compliance)?

RQ3: Did the association between campus sexual assault and institutional spending change with the 2011 issuance of the Dear Colleague Letter on sexual assault response?

RQ4: Is there a positive association between spending on student services or institutional support at one institution and the crimes or spending decisions at local institutions? 
RQ5: Is there a positive association between spending on student services or institutional support at one institution and the crimes or spending decisions at peer institutions?

\section{Interpretation of the Findings}

According to the data, there is a significant positive association between the number of reported crimes and sexual assaults and institutions' subsequent spending on student services. When broken down by institutional level, private four-year institutions had the strongest association, followed by public four-year and then public two-year. Survey respondents described their investments as going toward counseling services for victims, advocates, external services such as local women's shelters, and other, which included items such as assistance with filing a police report, transportation assistance in medical care, and accommodations related to classes.

Similarly, there is also a positive significant association between the number of reported crimes and sexual assaults and institutions' subsequent spending on institutional support. When broken down by institutional level, private four-year institutions once again had the strongest association, followed by public four-year and then public two-year. Survey respondents described their investments as going toward revised campus policies on sexual assault, trainings for faculty and staff, the addition of personnel whether through hiring or internal relocation and other, which included items such as published information on institutions website and communication campaigns.

Next, respondents were asked whether or not their institutions' spending changed with the issuance of the Dear Colleague Letter. This question found some mixed responses between the regression results and survey responses. According to the regression results, the fixed effects model suggests the student services response was larger, positive, and statistically significant 
after the Dear Colleague Letter in 2011, even though the financial response per crime was lower. However, according to survey responses, $54.2 \%$ of institutions said the amount their institution invests changed, with $71.58 \%$ of institutions saying this change resulted in a financial increase following the issuance of the Dear Colleague Letter, with only $2.11 \%$ saying they decreased their investment. When broken down by institutional level it was further found that $99.08 \%$ of responding four-year institutions increased their investment, along with $95.51 \%$ of responding two-year institutions. These institutions that increased their investment amount credited items such as federal mandates, state rules, student needs, media (local and social), professional organizations, and union contracts as influences on their institutional approach. Institutions that actually decreased their investment following the Dear Colleague Letter, however, noted constraints such as resource and staff as influencing this decision.

This study also wanted to assess whether or not competition between local institutions or institutions of the same type influenced each other. Specifically, it was asked if there is a positive association between spending on student services or institutional support at one institution and the crimes or spending decisions at institutions in the same state. According to the regression results, when broken down by institutional level, institutions actually saw a negative relationship for investments in both student services and institutional support when comparing their own investment amount to institutions in the same state. In support of this negative association, survey responses indicated that more than half of the institutions are not even aware of what institutions around them are investing and therefore this amount does not influence their own financial investment.

It was also asked whether or not a positive association between spending on student services or institutional support at one institution and the crimes and spending decisions at peer 
institutions exists. In support of this, the regression results indicated that when compared to institutions within the same peer group, financial investments into sexual assault prevention actually increase. However, according to the survey responses, only $1.52 \%$ of institutions are actually aware how much peer group institutions are even spending and from that, only $2.65 \%$ actually are influenced from this amount.

\section{Implications for Researchers}

\section{Reporting Issues}

Similar too many studies done before this one, this study reflects low levels of reporting. Not only did low levels of reporting impact the crime data abstracted from the U.S. Department of Education Crime and Safety website, but it also impacted people wanting to disclose information on the survey responses. In the past, it has been discovered that there are several potential explanations for the low levels of reporting of campus sexual assaults. One explanation for these low levels of reporting comes from the victims of the assaults being acquainted with their perpetrator, which more often than not makes the victim hesitant to report the incident (Karjane et al., 2005). These low levels of reporting become even more worrisome at institutions that do not provide a confidential reporting mechanism (McCaskill, 2014). Karjane et al. (2005) also found that victims are hesitant to report crimes in order to avoid further traumatization, shame, or public disclosure.

Even still, some victims just don't report the incident because they don't truly believe what happened to them meets the legal requirements of a sexual assault. Koss (1998) reported that only $27 \%$ of women who reported experiencing a sexual assault believed their incident actually met the legal criteria for rape. Building from this, Sinozich \& Langton (2014) found that $12 \%$ of all students who were assaulted were under the belief that their assault was not important 
enough to report. It also doesn't help this convoluted problem that at least half of all campus sexual assaults involve either drugs or alcohol (Abbey, 2002; Mohler-Kuo, Dowdall, Koss, \& Wechster, 2004), which make students scared to report in fear of legal repercussions or have a hazy recollection of the events that occurred during the incident.

This underreporting of sexual assaults caused a serious problem during my data collection. With the crime categories containing so many zeros, I was left with such small sample sizes that made my standard error so large that it was almost impossible to find significant effects between the crime variables and spending. In order to overcome this problem, I used category lumping. Instead of having different categories under the "sexual violence" umbrella, I had to lump all six categories (i.e., sexual offenses for both forcible and non-forcible, rape, fondling, incest and statutory rape) together to create one all-encompassing sexual assault variable.

It would be helpful in the future if institutions worked even harder to find successful ways of increasing victim reporting. Institutions need to ensure that the programs and procedures they are implementing for reporting allow for anonymous reporting to help students feel safe coming forward. Even more so, once victims report their crimes, there has to be a way to hold institutions accountable for properly reporting all of these incidents in their Clery Report. Sexual assault research will continue to suffer from underreporting issues until these issues are resolved at the institutional level.

After recognizing that some institutions consistently report more crimes, while other institutions report no crime at all, I used fixed effects in this study to help compare within same institutions over time as crime went up or down. These differences in reporting might actually reflect the number of crimes on campus, but it also may reflect the institutions effectiveness at reporting. Fixed effects are one way to account for these differences. In the future, another way 
to account for these differences would be to encourage more accurate crime reporting across institutions. Future research may also analyze judicial affair hearings and accusations as opposed to formal crime hearings.

\section{Outcome Variable: Spending}

This study is limited by having an imperfect measure of spending as the outcome variable. The intent of this study was to assess how much money in institutional support or student services is being spent annually in response to incidences of sexual violence. I defined institutional support as containing items such as legal counsel, Title IX compliance, audit, and oversight functions, and defined student services as containing items such as counseling, student activities, and student organizations. The problem is that the data for these variables that was extracted from IPEDS, contains more than just the items listed.

According to the IPEDS survey materials glossary, institutional support is,

"A functional expense category that includes expenses for the day to day operational support of the institution. Includes expenses for general administrative services, central executive-level activities concerned with management and long range planning, legal and fiscal operations, space management, employee personnel and records, logistical services such as purchasing and printing, and public relations and development. Also includes information technology expenses related to institutional support activities. If an institution does not separately budget and expense information technology resources, the IT costs associated with student services and operation and maintenance of plant will also be applied to this function" (National Center for Education Statistics, 2019).

Student services is defined as, 
"a functional expense category that includes expenses for admissions, registrar activities, and activities whose primary purpose is to contribute to students emotional and physical well-being and to their intellectual, cultural, and social development outside the context of the formal instructional program. Examples include student activities, cultural events, students newspapers, intramural athletics, students organizations, supplemental instruction outside the normal administration, and student records. Intercollegiate athletics and student health services may also be included except when operated as selfsupporting auxiliary activities...” (National Center for Education Statistics, 2019).

The problem here is that my outcome variable is noisy. Although it contains my intended spending outcome, it also contains other information. It would be beneficial if I could parse out the specific dollar amounts spent on each section of both institutional support or student services to eliminate some of this noise. Unfortunately, the data I had doesn't allow for this and I only have a total amount for each category. It would be beneficial if the National Center for Education Statistics defined and created financial variables solely focused on sexual assault response investment and added those variables to future IPEDS surveys. Since this kind of variable is not yet available in IPEDS, it would be helpful to look at IPEDS staffing variables instead of spending variables to see if similar patterns are evident for staff positions that are relevant to sexual assault response.

\section{Dropping Technical Schools}

Something that this study set out to do was address a gap in the literature by including technical schools in the survey analysis. Unfortunately, similar to other studies in the field, I had to drop technical schools due to insufficient data collected. With most studies that exist discussing sexual assault according to institutional control (i.e., private vs. public; New, 2016) or 
by institutional size (i.e., two-year vs. four-year), little is known about assaults at technical schools. This remains a major gap in the literature that future research should address.

\section{Implications for Practice}

\section{Resources across Different Types of Institutions}

According to the survey responses, some institutions want to make changes, but may have either staff or resource constraints that prohibit this from actually happening. For example, both two- and four-year institutions reported budget as being a major constraint on the way their institution responded. Some of these institutions noted budget as prohibiting them from maintaining certifications or receiving trainings, while others noted that budget constraints impacted the number of staff members employed to deal solely with campus sexual assault. For example, one two-year institution noted that their leaders determined their needs as being additional staff including a Title IX investigator and stronger networking with local sexual violence prevention agencies and shelters to improve awareness.

Also, many two-year institutions reported that due to resource constraints they outsource some of their prevention measures to the local community. Some community colleges have such severe resource constraints that they often times feel like they trail their four-year counterparts regarding policies and procedures that employ best practices. Leaders at two-year institutions often times also lack access to training as they are less likely to have full-time legal counsel, health care providers, robust student affairs divisions, or Title IX departments, which are more common at four-year institutions. For example, one two-year institution reported, "hard to focus on training and improving processes is difficult with so many employees at our institution wearing so many different hats. We don't have the luxury of having a team or a committee. Our employees who are responsible for Title IX have many other duties as well". This was also 
evident in the regression findings as community colleges had the smallest financial investment into student services and institutional support in response to each sexual assault report.

Understanding the gap between what is expected of institutions and what they are actually able to do is critically important in determining a path forward. Perhaps one way these resource gaps could be addressed is through institutions engaging in targeted fundraising to meet this need. State or local governments may also be able to help public institutions through supplemental funding based on response.

\section{Make Victims Feel Safe to Report}

As mentioned above, underreporting at institutions is due to a number of different factors including student fears of reporting to school officials or law enforcement, procedural gaps in how institutions respond to these incidents, or a combination of both. Despite institutions' legal obligation to address these issues through legislation such as Title IX and the Clery Act, improvements in both welcoming and encouraging student reporting of sexual assault and accurately disclosing this information in annual reporting has been slow at institutions across the nation. Moving forward, additional focus is needed to fully enforce Title IX and the Clery Act and guide institutions in understanding complete compliance with these laws.

\section{Implications for Policy \\ Dear Colleague Letter}

The Dear Colleague Letter made a huge impact on sexual assault prevention, one that should not be forgotten, even as this policy was rescinded under the current presidential administration (Melnick, 2018). As soon as a new administration takes office, changes occur and people tend to revert. The problem with this is there is a risk of losing and not learning. As the Trump administration continues to make changes regarding campus sexual assault, maybe 
institutions will choose to change course and move away from what the Dear Colleague Letter said, but there is an opportunity to seize on this and learn from this.

Survey respondents admitted that the Dear Colleague Letter influenced their institution to change their sexual assault prevention response. Specifically, $54.2 \%$ said the amount their institution invests in sexual assault prevention changed, with $71.58 \%$ saying this change resulted in a financial increase. According to the results of my regressions, although the Dear Colleague Letter increased reporting across institutions, institutional spending for both of these areas dropped considerably for individual crime reports. However, if reporting totals went up, this amount is still significant. Although this mismatch in data could stem from the noise in my outcome variable, this would be something to address with future research. The Dear Colleague Letter is a pivotal piece of legislation and the effects of it should be learned from, not forgotten.

\section{Conclusion}

This study assessed whether reports of sexual assault on campus increased an institution's financial investment in areas such as student services and institutional support. Through the use of ten years' worth of data (e.g. 2006-2015) from both IPEDS and the U.S. Department of Education Crime and Safety website and a survey that was sent to all available schools' Title IX Coordinators or Director of Student Service personnel, it was found that there is a significant positive association between the number of prior year crime reports and institutions' subsequent spending on student services (e.g. counseling) and institutional support (e.g. addition of personnel). Due to a lack of responses, technical schools had to be dropped from the analysis, but it is a gap in the literature I intend to address with future research. This study provides insight for both two- and four- year institutions as well as policymakers on the relationship between campus sexual assault and institutions' finances. 


\section{References}

Abbey, A. (2011). Alcohol's role in sexual violence perpetration: Theoretical explanations, existing evidence and future directions. Drug and alcohol review, 30(5), 481-489.

Adams, M. (2017, June 20). What contributes to rising college costs? EAB. Retrieved from: https://www.eab.com/research-and-insights/facilities-forum/expert-insights/2017/factorsaffecting-college-tuition

Aggeler, M. (2017, Aug. 26). What is the red zone? These 6 weeks are the dangerous time for campus sexual assault. Retrieved from: https://www.bustle.com/p/what-is-the-red-zone-these-6-weeksare-the-most-dangerous-time-for-campus-sexual-assault-79177

Amar, A. F., Strout, T. D., Simpson, S., Cardiello, M., \& Beckford, S. (2014). Administrators' perceptions of college campus protocols, response, and student prevention efforts for sexual assault. Violence and victims, 29(4), 579.

American Association of University Professors (2012, November). Campus Sexual Assault: Suggested Policies and Procedures. AAUP. Retrieved from: https://www.aaup.org/report/campus-sexualassault-suggested-policies-and-procedures.

Baker, K., \& Boland, K. (2011). Assessing safety: A campus-wide initiative. College student journal, 45(4), 683-700.

Bannon, R. S., Brosi, M. W., \& Foubert, J. D. (2013). Sorority women's and fraternity men's rape myth acceptance and bystander intervention attitudes. Journal of Student Affairs: Research and Practice, 50, 72-87.

Bieler, D. (2018, March 15). Baylor suspends four football players amind new sexual assault investigation. The Washington Post. Retrieved from: https;//www.google.com/amp/s/www.washingtonpost.com/amphtml/news/earlylead/wp/2018/03/15/baylor-suspends-four-football-players-amid-new-sexual-assaultinvestigation/

Blumenstyk, G. (1989). Public Higher-Education Systems Face Painful Choices as Three Northeastern States Confront Massive Deficits. Chronicle of Higher Education, 35(22).

Bowen, H. R. (1980). The Costs of Higher Education: How Much Do Colleges and Universities Spend per Student and How Much Should They Spend? http://lst-iiep.iiep-unesco.org/cgibin/wwwi32.exe/[in=epidoc1.in]/?t2000=015906/(100). 77. 10.2307/1981498.

Branch, K. A., Hayes-Smith, R., Richards, T. N. (2011). Professors' experiences with student disclosures of sexual assault and intimate partner violence: How "helping" students can inform teaching practices. Feminist Criminology, 6, 54-75. 
Brodsky, A. (2014, November 18). How much does sexual assault cost college students every year. The Washington Post. Retrieved from:

https://www.google.com/amp/s/www.washingtonpost.com/amphtml/posteverything/wp/2014/11/ 18/how-much-does-sexual-assault-cost-college-students-every-year/

Brodyaga, L., Gates, M., Singer, S., Tucker, M., \& White, R. (1975). Rape and its victims. Washington, DC: US Department of Justice.

Burnett, A., Mattern, J. L., Herakova, L. L., Kahl Jr, D. H., Tobola, C., \& Bornsen, S. E. (2009). Communicating/muting date rape: A co-cultural theoretical analysis of communication factors related to rape culture on a college campus. Journal of Applied Communication Research, 37(4), 465-485.

Burt, M. R. (1980). Cultural myths and supports for rape. Journal of personality and social psychology, $38(2), 217$.

Burt, M. R. (1998). Rape myths. Confronting rape and sexual assault. Confronting Rape and Sexual Assault. ME Clay-Warner, ed.(Rowman \& Littlefield, Lanham, MD), 129-144.

Camera, L. (2017, July 13). DeVos to move quickly to change Title IX guidance on sexual assault. U.S. News \& World Report. Retrieved from: https://www.usnews.com/news/educationnews/articles/2017-07-13/devos-to-move-quickly-to-change-title-ix-guidance-on-sexual-assault

Campbell, D. T., \& Stanley, J. C. (1963). Experimental and quasi-experimental designs for research. Handbook of research on teaching, 171-246.

Campbell, R., Townsend, S. M., Long, S. M., Kinnison, K. E., Pulley, E. M., Adames, S. B., \& Wasco, S. M. (2006). Responding to sexual assault victims' medical and emotional needs: A national study of the services provided by SANE programs. Research in nursing \& health, 29(5), 384398.

Campbell, R. \& Wasco, S. M. (2005). Understanding Rape and Sexual Assault: 20 years of progress and future directions. Journal of Interpersonal Violence, 20(1), 127-131

Cantalupo, N. C. (2011). Burying our heads in the sand: Lack of knowledge, knowledge avoidance, and the persistent problem of campus peer sexual violence. Loy. u. chi. LJ, 43, 205.

Cantor,D., Fisher, B., Chibnall, S. Townsend, R., et. al. (2015, Sept. 21). Report on the AAU campus climate survey on sexual assault and sexual misconduct. Association of American Universities $(A A U)$. Retrieved from: https://www.aau.edu/key-issues/aau-climate-survey-sexual-assault-andsexual-misconduct-2015

Cantor,D., Fisher, B., Chibnall, S. Townsend, R., et. al. (2017, Oct. 20). Report on the AAU campus climate survey on sexual assault and sexual misconduct. Association of American Universities $(A A U)$. Retrieved from: https://www.aau.edu/sites/default/files/AAU-Files/Key-Issues/CampusSafety/AAU-Campus-Climate-Survey-FINAL-10-20-17.pdf 
Carey, K. B., Durney, S. E., Shepardson, R. L., \& Carey, M. P. (2015). Incapacitated and forcible rape of college women: Prevalence across the first year. Journal of Adolescent Health, 56(6), 678680.

Carmody, D., Ekhomu, J., \& Payne, B. K. (2009). Needs of Sexual Assault Advocates in Campus-Based Sexual Assault Centers. College Student Journal, 43(2).

Carroll, C. M., Dahlgren, M. G., Grab, K. L., Hasbun, M. E., Hayes, M. A., \& Muntis, S. E. (2013). Implementing the Dear Colleague Letter: A Title IX case study for university compliance. Journal of the Student Personnel Association at Indiana University, 45-63.

Castellano, J. (2015, June 18). Campus sexual assault can cost universities millions. Forbes. Retrieved from: https://www.forbes.com/sites/jillcastellano/2015/06/18/campus-sexual-assault-can-costuniversities-millions/

Center for Disease Control and Prevention (CDC. (2012). Vital signs: preventing Clostridium difficile infections. MMWR. Morbidity and mortality weekly report, 61(9), 157.

Cheslock, J. J., Ortagus, J. C., Umbricht, M. R., \& Wymore, J. (2016). The Cost of Producing Higher Education: An Exploration of Theory, Evidence, and Institutional Policy. In Higher education: Handbook of theory and research (pp. 349-392). Springer International Publishing.

Chu, S. C. (2018, November 5). Harvard rolls out mandatory sexual assault prevention training for faculty and staff. The Harvard Crimson. Retrieved from: https://www.thecrimson.com/article/2018/11/5/title-ix-training-faculty-staff/

Clery Center. (2017). Clery act requirement. Retrieved from https://clerycenter.org/policy-resources/theclery-act/

Coker, A. L., Cook-Craig, P. G., Williams, C. M., Fisher, B. S., Clear, E. R., Garcia, L. S., \& Hegge, L. M. (2011). Evaluation of Green Dot: An active bystander intervention to reduce sexual violence on college campuses. Violence against women, 17(6), 777-796.

Conley, A. H., Overstreet, C. M., Hawn, S. E., Kendler, K. S., Dick, D. M., \& Amstadter, A. B. (2017). Prevalence and predictors of sexual assault among a college sample. Journal of American college health, 65(1), 41-49.

Coulter, R. W. S. \& Rankin, S. R. (2017). College sexual assault and campus climate for sexual- and gender-minority undergraduate students. Journal of Interpersonal Violence. Doi:10.1177/0886260517696870.

Daigle, L. E., Hoffman, C. Y., \& Johnson, L. M. (2016). The extent and risk of violent victimization among international college students enrolled in the United States: A gendered analysis. Journal of Interpersonal Violence. doi: 10.1177/0886260516633686. 
Day, K. (1994). Conceptualizing women's fear of sexual assault on campus: A review of causes and recommendations for change. Environment and Behavior, 26(6), 742-765.

Decker, S. E., \& Naugle, A. E. (2009). Immediate intervention for sexual assault: A review with recommendations and implications for practitioners. Journal of Aggression, Maltreatment \& Trauma, 18(4), 419-441.

DeKeseredy, W., \& Kelly, K. (1993). The incidence and prevalence of woman abuse in Canadian university and college dating relationships. Canadian Journal of Sociology/Cahiers canadiens de sociologie, 137-159.

DeMatteo, D., Galloway, M., Arnold, S., \& Patel, U. (2015). Sexual assault on college campuses: A 50state survey of criminal sexual assault statutes and their relevance to campus sexual assault. Psychology, Public Policy, and Law, 21(3), 227.

DeSantis, N. (2017, August 3). Federal sex-assault investigations are being resolved more often. These 11 cases show how. Chronicle of Higher Education. Retrieved from: https://www.chronicle.com/article/Federal-Sex-Assault/240848

Desrochers, D. M. \& Hurlburt, S. (2016, January). Trends in college spending: 2003-2013. Where does the money come from? Where does it go? What does it buy? American Institutes for Research. Retrieved from: https://www.deltacostproject.org/sites/default/files/products/154626\%20Final01\%20Delta\%20Cost\%20Project\%20College\%20Spending\%2011131.406.P0.02. $001 \% 20 \ldots . . p d f$

Eaton- Robb, P. (2013, November 1). Women file sex discrimination lawsuit against UConn. NBC Connecticut. Retrieved from: https://www.google.com/amp/s/www.nbcconnecticut.com/news/local/-Women-Filing-SexDiscrimination-Lawsuit-Against-Uconn-Lawyer-230224681.html\%3famp=y

Englander, E., McCoy, M., \& Sherman, S. (2016). Sexual assault information on university websites. Violence and gender, 3(1), 64-70.

Engle, J. C. (2014). Mandatory reporting of campus sexual assault and domestic violence: Moving to a victim-centric protocol that comports with federal law. Temp. Pol. \& Civ. Rts. L. Rev., 24, 401.

Findley, P. A., Plummer, S. B., \& McMahon, S. (2016). Exploring the experiences of abuse of college students with disabilities. Journal of Interpersonal Violence, 31, 2801-2823.

Fisher, B. S. (1995). Crime and fear on campus. The Annals of the American Academy of Political and Social Science, 539(1), 85-101.

Fisher, B. S., Cullen, F. T., \& Turner, M. G. (2000). The Sexual Victimization of College Women. Research Report. 1-36. 
Fisher, B. S., Daigle, L. E., \& Cullen, F. T. (2010). Unsafe in the ivory tower: The sexual victimization of college women. Sage Publications.

Fisher, B. S., Daigle, L. E., Cullen, F. T., \& Turner, M. G. (2003). Reporting sexual victimization to the police and others: Results from a national-level study of college women. Criminal Justice and Behavior, 30, 6-38.

Fisher, B. S., Sloan, J. J., Cullen, F. T., \& Lu, C. (1998). Crime in the ivory tower: The level and sources of student victimization. Criminology, 36(3), 671-710.

Flack Jr, W. F., Hansen, B. E., Hopper, A. B., Bryant, L. A., Lang, K. W., Massa, A. A., \& Whalen, J. E. (2016). Some types of hookups may be riskier than others for campus sexual assault. Psychological trauma: theory, research, practice, and policy, 8(4), 413.

Ford, J., Soto-Marquez, J.G. (2016). Sexual Assault victimization among straight, gay/lesbian, and bisexual college students. Violence and Gender, 3, 107-115.

Frank, R. H. (1999). Higher education: The ultimate winner-take-all market?

Gidycz, C. A., Orchowski, L. M., King, C. R., \& Rich, C. L. (2008). Sexual victimization and healthrisk behaviors: A prospective analysis of college women. Journal of interpersonal violence, 23(6), 744-763.

Gidycz, C. A., Orchowski, L. M., Probst, D. R., Edwards, K. M., Murphy, M., \& Tansill, E. (2015). Concurrent administration of sexual assault prevention and risk reduction programming: Outcomes for women. Violence against women, 21(6), 780-800.

Glass, N. (2013). Sexual assault reporting in college. Sprinkle: An Undergraduate Journal of Feminist and Queer Studies, 5, 32-38.

Gordon, M. T., \& Riger, S. (1989). The female fear. New York: Free Press.

DeGue, S. (2014). Preventing Sexual Violence on College Campuses: Lessons from Research and Practice.

Dunn, L. L. (2013). Addressing sexual violence in higher education: Ensuring compliance with the Clery Act, Title IX and VAWA. Geo. J. Gender \& L., 15, 563.

Hayes-Smith, R. M., \& Levett, L. M. (2010). Student perceptions of sexual assault resources and prevalence of rape myth attitudes. Feminist Criminology, 5(4), 335-354.

Helwick, C. (2015, December 8). Are colleges obligated to protect students from crimes by other students? Inside Higher Ed. Retrieved from: https://www.insidehighered.com/views/2015/12/08/are-colleges-obligated-protect-studentscrimes-other-students-essay 
Henrick, S. (2013, April). A hostile environment for student defendants: Title IX and sexual assault on college campuses.

Hoffower, H. (2018, July 8). College is more expensive than it's ever been and the 5 reasons why suggest it's only going to get worse. Business Insider. Retrieved from: https://www.google.com/amp/s/amp.businessinsider.com/why-is-college-so-expensive-2018-4

Howard, B. (2015, August 28). How colleges are battling sexual violence. U.S. News. Retrieved from: https://www.usnews.com/news/articles/2015/08/28/how-colleges-are-battling-sexual-violence

Janosik, S. M. (2001). The impact of the Campus Crime Awareness Act of 1998 on student decisionmaking. NASPA journal, 38(3), 348-360.

Janosik, S. M., \& Gregory, D. E. (2003). The Clery Act and its influence on campus law enforcement practices. Naspa Journal, 41(1), 182-199.

Janosik, S. M., \& Plummer, E. (2005). The Clery Act, Campus Safety and the Views of Assault Victim Advocates. College Student Affairs Journal, 25(1), 116-130.

Jaschik, S. (2013, January 29). The customer is always right? Inside Higher Ed. Retrieved from: http://www.insidehighered.com/news/2013/01/29/many-students-opt-colleges-spend-morenonacademic-functions-study-finds

Johnson, K.C. and Taylor, S. (2017, January 31). The path to Obama's 'Dear Colleague' letter. The Washington Post. Retrieved from: https://www.insidehighered.com/news/2017/04/06/sexualassault-claims-can-be-costly

Joyce, K. (2017, December 5). The takedown of Title IX. Inside the fight over federal rules on campus sexual assault. The New York Times. Retrieved from: http://www.nytimes.com/2017/12/05/magazine/the-takedown-of-title-ix.amp.html

Karjane, H. M., Fisher, B. S., \& Cullen, F. T. (2002). Campus Sexual Assault: How America’s Institutions of Higher Education Respond, final report. National Institute of Justice.

Karjane, H. M., Fisher, B. S., \& Cullen, F. T. (2005). Sexual assault on campus: What colleges and universities are doing about it. Washington, DC: U.S. Department of Justice.

Katz, J. \& Moore, J. (2013). Bystander education for campus sexual assault prevention: An initial metaanalysis. Violence \& Victims, 28, 1054-1067.

Kilpatrick, D. G., \& Acierno, R. (2003). Mental health needs of crime victims: Epidemiology and outcomes. Journal of Traumatic Stress: Official Publication of The International Society for Traumatic Stress Studies, 16(2), 119-132. 
Kimble, M., Neacsiu, A. D., Flack, W. F., \& Horner, J. (2008). Risk of unwanted sex for college women: Evidence for a red zone. Journal of American College Health, 57(3), 331-338.

Kirk, A. F. (2014, May 19). Think college costs too much? Thank the government. Chronicle of Higher Education, 60(36), A34-A35. Retrieved from: https://www.chronicle.com/article/Think-CollegeCosts-Too-Much-/146641

Kitchener, C. \& Harris, A. (2018, August 30). A step-by-step guide to Trump's new college sexualassault policy. The Atlantic. Retrieved from:

https://www.theatlantic.com/education/archive/2018/08/a-guide-to-how-the-new-rules-oncampus-sexual-assault-could-work/569035/

Koss, M. P., Gidycz, C. A., \& Wisniewski, N. (1987). The scope of rape: Incidence and prevalence of sexual aggression and victimization in a national sample of higher education students. Journal of Consulting and Clinical Psychology, 55, 162-170.

Koss, M. P. (1998). Hidden rape: Sexual aggression and victimization in a national sample of students in higher education.

Krebs, C. P., Lindquist, C. H., \& Barrick, K. (2011). The historically black college and university campus sexual assault (HBCU-CSA) study. Washington, DC: The National Institute for Justice.

Krebs, C. P., Lindquist, C. H., Warner, T. D., Fisher, B. S., \& Martin, S. L. (2007). The Campus Sexual Assault (CSA) study. Washington, DC: The National Institute for Justice

Krebs, C. P., Lindquist, C. H., Warner, T. D., Fisher, B. S., \& Martin, S. L. (2009). College women's experiences with physically forced, alcohol- or other drug-enabled, and drug-facilitated sexual assault before and since entering college. Journal of American College Health, 57, 639-649.

Krivoshey, M. S., Adkins, R., Hayes, R., Nemeth, J. M., \& Klein, E. G. (2013). Sexual assault reporting procedures at Ohio colleges. Journal of American College Health, 61, 142-147.

Lake, P.F. (2017, September 24). "Interim" guidance on Title IX creates confusion, not clarity. Chronicle of Higher Education. Retrieved from: https://www.chronicle.com/article/InterimGuidance-on/241282

Landreman, L. M., \& Williamsen, K. M. (2018). Addressing Sexual Violence as Student Affairs Work. New Directions for Student Services, 2018(161), 35-45.

Leef, G. (2014, August 20). The Clery Act: Greater campus safety, or just greater cost? Forbes. Retrieved from: https:/www.forbes.com/sites/georgeleef/2014/08/20/the-clery-act-greatercampus-safety-or-just-greater-cost/\#c1d94f355cda

Lentz, M. A. (2013). Title IX and 1983: Actual knowledge and deliberate indifference. Lentz School Security, 4, 11. 
Leslie, L. L., \& Rhoades, G. (1995). Rising administrative costs: Seeking explanations. The Journal of Higher Education, 66(2), 187-212.

Leslie, L. L., Slaughters, S., Taylor, B. J., \& Zhang, L. (2012). How do revenue variations affect expenditures within U.S. research universities? Research in Higher Education, 53(6), 614-639.

Lichty, L. F., Campbell, R., \& Schuiteman, J. (2008). Developing a university-wide institutional response to sexual assault and relationship violence. Journal of Prevention \& Intervention in the Community, 36(1-2), 5-22.

Lindo, J. M., Marcotte, D. E., Palmer, J. E., \& Swensen, I. D. (2018). Any press is good press? The unanticipated effects of Title IX investigations on university outcomes. NBER Working Paper Series, 1-28.

Lindquist, C. H., Barrick, K., Krebs, C., Crosby, C. M., Lockard, A. J., \& Sanders-Phillips, K. (2013). The context and consequences of sexual assault among undergraduate women at historically black colleges and universities (HBCUs). Journal of Interpersonal Violence, 28, 2437-2461.

Lippy, C., \& DeGue, S. (2016). Exploring alcohol policy approaches to prevent sexual violence perpetration. Trauma, Violence, \& Abuse, 17(1), 26-42.

Lombardi, K. (2009). Sexual assault on campus shrouded in secrecy. The Center for Public Integrity.

Lombardi, K. (2010). A lack of consequences for sexual assault. Washington, DC: Center for Public Integrity. Retrieved January 21, 2019.

Luca, M., Rooney, P., \& Smith, J. (2016). The impact of campus scandals on college applications. Harvard Business School (pp. 16-137). Working Paper.

Luca, M., \& Smith, J. (2013). Salience in quality disclosure: evidence from the US News college rankings. Journal of Economics \& Management Strategy, 22(1), 58-77.

Lund, E. M., \& Thomas, K. B. (2015). Necessary but not sufficient: Sexual assault information on college and university websites. Psychology of Women Quarterly, 39(4), 530-538.

Malafronte, K. (2018, October 3). University of Montana fined close to \$1M for Clery Act Violations. Campus Safety. Retrieved from: https://www.campussafetymagazine.com/clery/university-ofmontana-fined-close-to-1m-for-clery-act-violations/

Mancini, C., Pickett, J. T., Call, C., \& Roche, S. P. (2016). Mandatory reporting (MR) in higher education: College students' perceptions of laws designed to reduce campus sexual assault. Criminal justice review, 41(2), 219-235.

Martin, P. Y. (2016). The rape prone culture of academic contexts: Fraternities and athletics. Gender \& Society, 30(1), 30-43. 
Martin, R. \& Gillen, A. (2009, August 7). Breaking the cost spiral. Inside Higher Ed. Retrieved from: http://www.insidehighered.com/views/2009/08/07/breaking-cost-spiral.

Martin, P. Y., \& Hummer, R. A. (1989). Fraternities and rape on campus. Gender \& Society, 3(4), $457-$ 473.

Mause, K. (2009). Too Much Competition in Higher Education? Some Conceptual Remarks on the Excessive-Signaling Hypothesis. American Journal of Economics and Sociology, 68(5), 11071133.

McCaskill, C. (2014). Sexual violence on campus. Report, US Senate Subcommittee on Financial and Contracting Oversight.

McCauley, J., Ruggiero, K. J., Resnick, H. S., Conoscenti, L. M., \& Kilpatrick, D. G. (2009). Forcible, drug-facilitated, and incapacitated rape in relation to substance use problems: Results from a national sample of college women. Addictive Behaviors, 34(5), 458-462.

McClure, K. R. \& Marvin, A. T. (2018). Spending up the ranks? The relationship between striving for prestige and administrative expenditures at U.S. public research universities. The Journal of Higher Education, 89(6), 961-987. Doi: 10.1080/00221546.2018.1449079.

McMahon, P. (2008). Sexual violence on the college campus: A template for compliance with federal policy. J Am Coll Health, 57, 361-365.

Meilman, P. W., Riggs, P., \& Turco, J. H. (1990). A college health service's response to sexual assault issues. Journal of American College Health, 39(3), 145-147.

Melnick, R. S. (2018). Rethinking federal regulation of sexual harassment. Education Next, 18(1), 9-15.

Mitra, M. (2018, November 20). The most horrifying part of the Dartmouth sexual harassment case. The Washington Post. Retrieved from: https://www.google.com/amp/s/www.washingtonpost.com/amphtml/blogs/postpartisan/wp/2018/11/20/the-most-horrifying-part-of-the-dartmouth-sexual-harassment-case/

Mohler-Kuo, M., Dowdall, G. W., Koss, M. P., \& Wechsler, H. (2004). Correlates of rape while intoxicated in a national sample of college women. Journal of studies on alcohol, 65(1), 37-45.

Moylan, C. A. (2017). “I fear I'm a checkbox": College and University victim advocates' perspectives of campus rape reforms. Violence Against Women, 23(9), 1122-1139.

Moylan, C. A. \& Javorka, M. (2018). Widening the lens: An ecological review of campus sexual assault. Trauma, Violence, and Abuse, 1524838018756121.

Muehlenhard, C. L. \& Linton, M. (1987). Date rape and sexual aggression in dating situations: Incidence and risk factors. Journal of Counseling Psychology, 34(2), 186-196. 
Muehlenhard, C. L., Peterson, Z. D., Humphreys, T. P., \& Jozkowski, K. N. (2017). Evaluating the onein-five statistic: Women's risk of sexual assault while in college. The Journal of Sex Research, 54(4-5), 549-576.

Murnen, S. K., \& Kohlman, M. H. (2007). Athletic participation, fraternity membership, and sexual aggression among college men: A meta-analytic review, Sex Roles, 57, 145-157.

Nasta, A., Shah, B., Brahmanandam, S., Richman, K., Wittels, K., Allsworth, J., \& Boardman, L. (2005). Sexual victimization: Incidence, knowledge and resource use among a population of college women. Journal of Pediatric and Adolescent Gynecology, 18, 91-96.

National Center for Education Statistics (2019). 2019-20 Survey Materials-Glossary. U.S. Department of Education. Retrieved from: https://surveys.nces.ed.gov/ipeds/Downloads/Forms/IPEDSGlossary.pdf

National Domestic Violence Hotline, (n.d.). What is the violence against women act? Retrieved from https://www.thehotline.org/resources/vawa/

National Sexual Violence Resource Center (2015). Statistics about sexual violence. Retrieved from: https://www.nsvrc.org/sites/default/files/publications_nsvrc_factsheet_media-packet_statisticsabout-sexual-violence_O.pdf

Nelson, G. (2015). The high cost of sexual assaults on college campuses. Nonprofit Quarterly.

New, J. (2016, December 16). Burden of proof in the balance. Inside Higher Ed. Retrieved from: https://www.insidehighered.com/news/2016/12/16/will-colleges-still-use-preponderanceevidence-standard-if-2011-guidance-reversed

Newlon C. (2014, June 16). After campus rape allegations, some alums deny donations. Forbes. Retrieved from: https://www.forbes.com/sites/caranewlon/2014/06/16/after-campus-rapeallegations-some-alums-deny-donations/\#74445c1a6295

Nicholson, M. E., Maney, D. W., Blair, K., Wamboldt, P. M., Mahoney, B.S., \& Yuan, J.(1998). Trends in alcohol-related campus violence: Implication for prevention. Journal of Alcohol and Drug Education, 43(3), 35-52.

Novkov, J. (2015). Equity, process, and campus sexual assault, Md. L. Rev., 75, 590.

Oehme, K., Stern, N., \& Mennicke, A. (2015). A deficiency in addressing campus sexual assault: The lack of women law enforcement officers. Harv. Women's LJ, 38, 337.

Payne, D. L., Lonsway, K. A., \& Fitzgerald, L. F. (1999). Rape myth acceptance: Exploration of its structure and its measurement using theIllinois rape myth acceptance scale. Journal of Research in Personality, 33(1), 27-68. 
Patterson Silver Wolf, D. A., Perkins, J., Van Zile-Tamsen, C., \& Butler-Barnes, S. (2016). Impact of violence and relationship abuse on grades of American Indian/Alaska Native undergraduate college students. Journal of Interpersonal Violence. doi: 10.1177/10886260516639255

Perrin, M., Vandeleur, C. L., Castelao, E., Rothen, S., Glaus, J., Vollenweider, P., \& Preisig, M. (2014). Determinants of the development of post-traumatic stress disorder, in the general population. Social psychiatry and psychiatric epidemiology, 49(3), 447-457.

Petrak, J. (2002). The psychological impact of sexual assault. The trauma of sexual assault: Treatment, prevention, and practice, 19-44.

RAINN (2019). The criminal justice system: statistics. RAINN. Retrieved from: https://www.rainn.org/statistics/criminal-justice-system

Ray, J. (2013). Rape and rape culture on college campuses. Sprinkle: An Undergraduate Journal of Feminist and Queer Studies, 5, 39.

Rennison, C. M. (2002). Rape and sexual assault: Reporting to police and medical attention, 19922000. Washington, DC: US Department of Justice, Office of Justice Programs.

Rennison, C. M., \& Addington, L. A. (2014). Violence against college women: A review to identify limitations in defining the problem and inform future research. Trauma, Violence, \& Abuse, 15, 159-169.

Richards, T. N., \& Kafonek, K. (2016). Reviewing state legislative agendas regarding sexual assault in higher education: Proliferation of best practices and points of caution. Feminist criminology, 11(1), 91-129.

Russell, L. (2017). Market power effects of college and university mergers. Massachussetts Institute of Technology, Cambridge, US.

Sabin, M. (2006). Antitrust and Positional Arms Race. Harv. JL \& Pub. Pol'y, 30, 1023.

Sabina, C., \& Ho, L. Y. (2014). Campus and college victim responses to sexual assault and dating violence: Disclosure, service utilization, and service provision. Trauma, Violence, \& Abuse, 15(3), 201-226.

Sampson, R. (2002). Acquaintance rape of college students. Washington, DC: US Department of Justice, Office of Community Oriented Policing Services.

Scherer, H. L., Snyder, J. A., \& Fisher, B. S. (2016). Intimate partner victimization among college students with and without disabilities: Prevalence of and relationship to emotional well-being. Journal of Interpersonal Violence, 31, 49-80.

Schroeder, L. P. (2014). Cracks in the ivory tower: How the Campus Sexual Violence Elimination Act can protect students from sexual assault. Loy. U. Chi. LJ, 45, 1195. 
Schwartz, M. D., \& Nogrady, C. A. (1996). Fraternity membership, rape myths, and sexual aggression on a college campus. Violence Against Women, 2(2), 148-162.

Serio, T. (2018, April 2). Colleges must confront sexual assault and sexual harassment head on. The Conversation. Retrieved from: https://theconversation.com/colleges-must-confront-sexualassault-and-sexual-harassment-head-on-93054.

Shadish, W. R., Cook, T. D., \& Campbell, D. T. (2002). Experimental and quasi-experimental designs for generalized causal inference/William R. Shedish, Thomas D. Cook, Donald T. Campbell. Boston: Houghton Mifflin,.

Sienkiewicz, T. (2018, December 19). Resources for college student survivors of sexual assault. Peterson's. Retrieved from: https://www.google.com/amp/s/www.petersons.com/blog/resourcesfor-college-student-survivors-of-sexual-assault/\%3famp

Silbaugh, K. (2015). Reactive to Proactive: Title IX's Unrealized Capacity to Prevent Campus Sexual Assault. BUL Rev., 95, 1049.

Silverstein, H. (2018, October 15). President Hanlon announces plan for sexual misconduct policy. Dartmouth News. Retrieved from: https://news.dartmouth.edu/news/2018/10/president-hanlonannounces-plan-sexual-misconduct-policy

Sinozich, S., \& Langton, L. (2014). Rape and sexual assault victimization among college-age females, 1995-2013. Washington, DC: US Department of Justice, Office of Justice Programs, Bureau of Justice Statistics.

Sloan III, J. J., Fisher, B. S., \& Cullen, F. T. (1997). Assessing the student right-to-know and Campus Security Act of 1990: An analysis of the victim reporting practices of college and university students. Crime \& Delinquency, 43(2), 148-168.

Smith, M. C. (1988). Coping with crime on campus. New York: Macmillan.

Söchting, I., Fairbrother, N., \& Koch, W. J. (2004). Sexual assault of women: Prevention efforts and risk factors. Violence against women, 10(1), 73-93.

Somanader, T. (2014, September 19). President Obama launches "It's on Us" campaign to end sexual assault on campus. The White House. Retrieved from: https://obamawhitehouse.archives.gov/blog/2014/09/19/president-obama-launches-its-uscampaign-end-sexual-assault-campus

Staff, C.S. (2016, November 3). Department of Ed levies \$2.4M fine against Penn State over Sandusky case. Campus Safety. Retrieved from: https://www.campussafetymagazine.com/news/dept_of_ed_levies_2-4m_fine_against_penn_state_over_sandusky_case/ 
Stotzer, R. L., \& MacCartney, D. (2016). The role of institutional factors on on-campus reported rape prevalence. Journal of interpersonal violence, 31(16), 2687-2707.

Streng, T. K., \& Kamimura, A. (2015). Sexual Assault Prevention and Reporting on College Campuses in the US: A Review of Policies and Recommendations. Journal of Education and Practice, $6(3), 65-71$.

Tate, E. (2017, April 6). The high (dollar) cost of sexual assault. Inside Higher Ed. Retrieved from: https://www.insidehighered.com/news/2017/04/06/sexual-assault-claims-can-be-costly

Taylor, Z. W. (2018). Unreadable and Underreported: Can College Students Comprehend How to Report Sexual Assault?. Journal of College Student Development, 59(2), 248-253.

The White House (2014, April). Not alone: The first report of the White House task force to protect students from sexual assault. Retrieved from: https://www.justice.gov/archives/ovw/page/file/905942/download

Thompson, C. (2016). Penn State says it will pay record Clery Act fine of \$2.4 million. Penn Live. Retrieved from: https://www.google.com/amp/s/articles.pennlive.com/politics/index.ssf/2016/11/penn_state_says _it_will_pay_re.amp

Title IX, 20 U.S.C. 1681-1688 (2006).

Ullman, S. E., \& Brecklin, L. R. (2003). Sexual assault history and health-related outcomes in a national sample of women. Psychology of Women Quarterly, 27(1), 46-57.

United Educators Insurance, supra note, 44 at 17-18.

United States Department of Justice, Federal Bureau of Investigation, Uniform Crime Report, (2014). Crime in the United States.

United States Department of Justice, Office of Violence Against Women (OVW), (2019). Retrieved from https://www.justice.gov/ovw/sexual assault.

U.S. Department of Education, Office of Civil Rights. (2018, September). Know your rights: Title IX prohibits sexual harassment and sexual violence where you go to school. Washington, DC: U.S. Department of Education Press Office. Retrieved from https://www2.ed.gov/about/offices/list/ocr/docs/title-ix-rights-201104.html

U.S. Department of Education, Office of Civil Rights (2014, April). The Assistant Secretary. Retrieved from https:www2.ed.gov/about/offices/list/ocr/docs/qa-201404-title-ix.pdf.

U.S. Senate Subcommittee on Financial and Contracting Oversight. (2014). Sexual violence on campus. Retrieved from https://www.mccaskill.senate.gov/SurveyReportwithAppendix.pdf 
Vladutiu, C. J., Martin, S. L., \& Macy, R. J. (2011). College-or university-based sexual assault prevention programs: A review of program outcomes, characteristics, and recommendations. Trauma, Violence, \& Abuse, 12(2), 67-86.

von Spakovsky, H. (2017, July 25). Campus sexual assault: Understanding the problem and how to fix it. The Heritage Foundation. Retrieved from: https://www.heritage.org/crime-andjustice/report/campus-sexual-assault-understanding-the-problem-and-how-fix-it

Winston, G. C. (2000). The positional arms race in higher education (No. 54). WPEHE Discussion Paper Series/Williams College, Williams Project on the Economics of Higher Education.

Wolitzky, K. B., Resnick, H. S., Amstadter, A. B., McCauley, J. L., Ruggiero, K. J., and Kilpatrick, D. G. (2011). Reporting rape in a national sample of college women. J Am Coll Health, 59(7), 582587.

Yung, C. R. (2015). Concealing campus sexual assault: An empirical examination. Psychology, Public Policy, and Law, 21, 1-9.

Zamudio-Suarez, F. (2017). Education Dept. replaces Obama-era Title IX directives with new interim guidance.

Zinzow, H. M., Resnick, H. S., Amstadter, A. B., McCauley, J. L., Ruggiero, K. J., \& Kilpatrick, D. G. (2010). Drug-or alcohol-facilitated, incapacitated, and forcible rape in relationship to mental health among a national sample of women. Journal of Interpersonal Violence, 25(12), 22172236.

Zinzow, H. M., \& Thompson, M. (2011). Barriers to reporting sexual victimization: Prevalence and correlates among undergraduate women. Journal of Aggression, Maltreatment \& Trauma, 20(7), 711-725. 


\section{Tables}

\section{Table 1}

\begin{tabular}{lllll}
$\begin{array}{l}\text { Variable } \\
\text { Observations: 85,161 }\end{array}$ & Mean & $\begin{array}{l}\text { Standard } \\
\text { Deviation }\end{array}$ & Min. & Max. \\
\hline Non-residential Males & 58.46 & 270.90 & 0 & 6373 \\
Non-residential Females & 49.20 & 217.31 & 0 & 9060 \\
Black Males & 129.36 & 364.83 & 0 & 13019 \\
Black Females & 229.31 & 752.43 & 0 & 45908 \\
American Indian/Alaskan & 9.18 & 38.73 & 0 & 1498 \\
Native Males & & & & \\
American Indian/Alaskan & 13.92 & 62.16 & 0 & 2016 \\
Native Females & & & & 7389 \\
Asian Males & 72.87 & 322.28 & 0 & 11245 \\
Asian Females & 83.79 & 352.20 & 0 & 19464 \\
Hispanic Males & 167.33 & 654.87 & 0 & 27342 \\
Hispanic Females & 235.50 & 888.98 & 0 & 88586 \\
White Males & 667.03 & 1650.47 & 0 & 81399.87 \\
White Females & 855.85 & 1991.60 & 0 & 1 \\
Public Institutions & 1137.11 & 3792.492 & 0 & $351,000,000$ \\
Four-year Institutions & 0.4147 & 0.4927 & 0 & $1,180,000,000$ \\
Student Service Expenses & $7,154,580$ & $14,200,000$ & 0 & 81399.87 \\
Institutional Support & $12,300,000$ & $31,100,000$ & -4508923 & $10,200,000,000$ \\
Expenses & 1137.111 & 3792.492 & 0 & 223 \\
Revenue Total & $123,000,000$ & $434,000,000$ & $-10,100,000,000$ \\
Overall Crime Total & .7955 & 3.586 & 0 &
\end{tabular}




\section{Table 2}

Undergraduate

\begin{tabular}{|c|c|c|c|c|c|c|c|c|c|}
\hline $\begin{array}{l}\text { Variable } \\
\text { Observations: } \\
81,405\end{array}$ & Mean & $\begin{array}{l}\text { Standard } \\
\text { Deviation }\end{array}$ & Min. & Max. & $\begin{array}{l}\text { Variable } \\
\text { Observations: } \\
24,665\end{array}$ & Mean & $\begin{array}{l}\text { Standard } \\
\text { Deviatio } \\
\mathrm{n}\end{array}$ & Min. & Max. \\
\hline $\begin{array}{l}\text { Non-residential } \\
\text { Females }\end{array}$ & 30.61 & 128.61 & 0 & 5172 & $\begin{array}{l}\text { Non-residential } \\
\text { Females }\end{array}$ & 68.22 & 209.44 & 0 & 5172 \\
\hline Black Males & 122.67 & 337.67 & 0 & 10401 & Black Males & 41.38 & 128.67 & 0 & 10401 \\
\hline Black Females & 209.77 & 647.17 & 0 & 3635 & Black Females & 99.42 & 401.73 & 0 & 36035 \\
\hline $\begin{array}{l}\text { American } \\
\text { Indian/Alaskan } \\
\text { Native Males }\end{array}$ & 8.86 & 37.69 & 0 & 1498 & $\begin{array}{l}\text { American } \\
\text { Indian/Alaskan } \\
\text { Native Males }\end{array}$ & 2.34 & 6.72 & 0 & 1498 \\
\hline Asian Males & 65.75 & 296.20 & 0 & 7389 & Asian Males & 32.67 & 94.59 & 0 & 7389 \\
\hline Asian Females & 74.62 & 319.23 & 0 & 11245 & Asian Females & 40.68 & 114.75 & 0 & 11245 \\
\hline Hispanic Males & 164.09 & 643.84 & 0 & 19464 & Hispanic Males & 35.63 & 98.45 & 0 & 19464 \\
\hline $\begin{array}{l}\text { Hispanic } \\
\text { Females }\end{array}$ & 227.63 & 859.41 & 0 & 27342 & Hispanic Females & 61.74 & 184.78 & 0 & 27342 \\
\hline
\end{tabular}


Figure 1

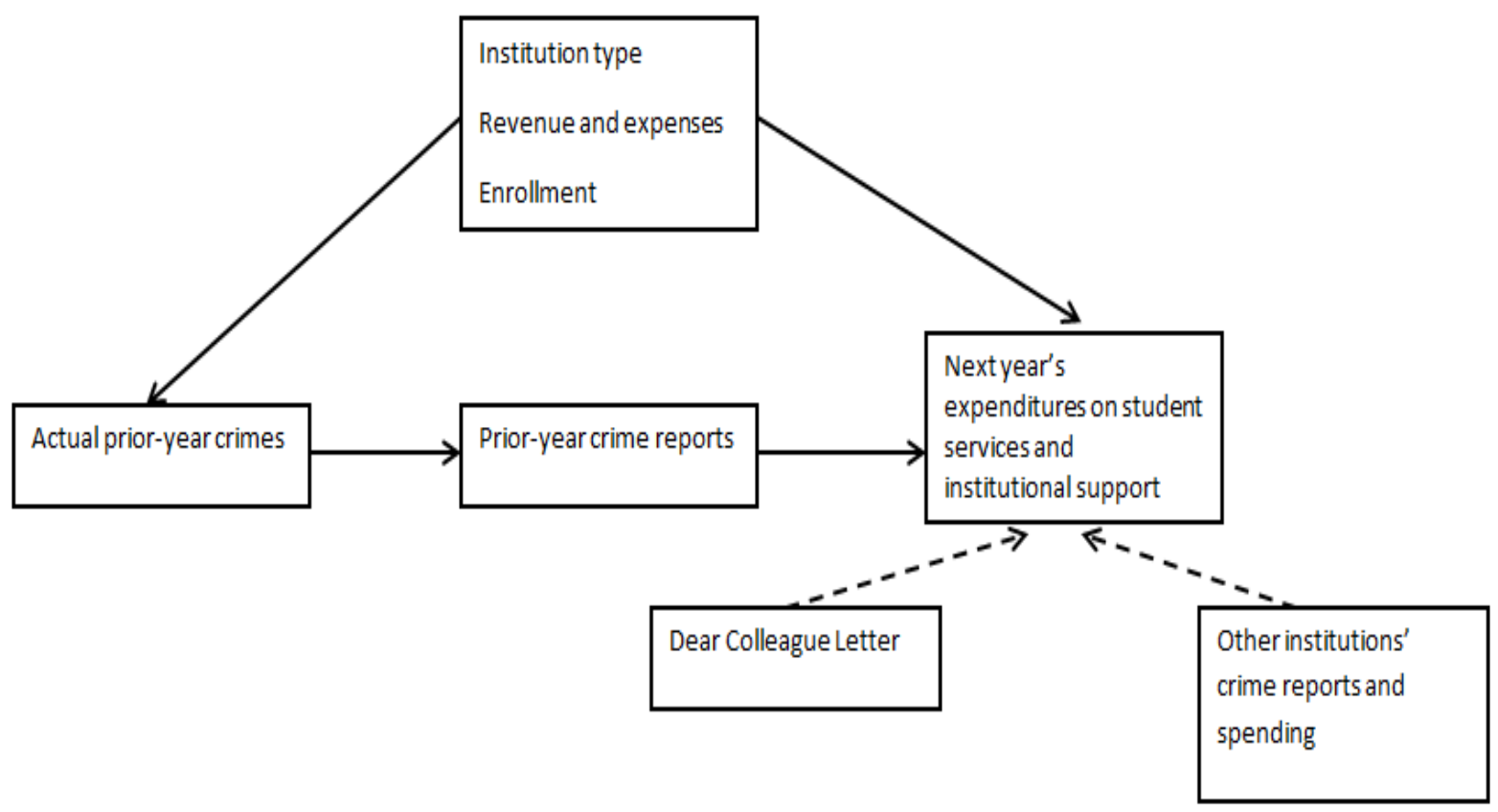




\section{Figure 2}

IRB \#: 1903503465

Dear Participant,

I am reaching out to request your participation in a research project exploring how much each reported sexual assault is costing your institution. This project is being conducted by Amanda Rose, a doctoral candidate in the Higher Education Administration PhD program at West Virginia University, under the supervision of Dr. Hughes. Your participation in this project is greatly appreciated and will take approximately 15 minutes to fill out the attached questionnaire. This email serves as a reminder to please participate as the research is only open for another two weeks.

Your involvement in this project will be kept as confidential as legally possible. No identifiable information will be reported, including your institutions name. You must be 18 years of age or older to participate. Your participation is completely voluntary. You may skip any question that you do not wish to answer and you may discontinue at any time. West Virginia University's Institutional Review Board's acknowledgement of this project is on file.

I hope that you will participate in this research project, as it could be beneficial in understanding the impact of sexual assaults on an institutions bottom line. Thank you very much for your time. Should you have any questions about this letter or the research project, please feel free to contact Amanda Rose at (724) 216-3116 or by e-mail at ampozzuto@mix.wvu.edu.

With the responses being confidential, I am unsure of who has already responded. Therefore, if you have already taken the time to help my dissertation research and responded to the survey I want to thank you for your time and help in this process.

Sincerely,

Amanda Rose 
Figure 3

Survey Questions

1. Age

- Under 20

$-20-29$

$-30-39$

$-40-49$

$-50-59$

$-60+$

2. Gender

- Male

- Female

- Other:

\section{Ethnicity}

- White

- Black or African American

- Hispanic or Latino

- American Indian or Alaska Native

- Asian

- Native Hawaiian or Pacific Islander

- Other

4. My institution can best be described as:

- 4-year institution

- 2-year institution 
- Technical school

5. Please indicate your institution's total enrollment as of school year 2018-2019:

- fewer than 5,000

$-5,001-15,000$

$-15,001-25,000$

$-25,001-35,000$

$-35,001-45,000$

$-45,001-55,000$

$-55,001-65,000$

- > 65,000

6. Does your institution annually complete a Clery Report?

7. Did the amount your institution invests change with the passing of the Dear Colleague Letter in 2011 ?

7a. Did it increase or decrease?

7b. Did the passing of the Dear Colleague Letter influence sexual assault response on your campus in any other ways?

8. Does your institution require a Title IX Coordinator to be staffed? If so, is this the position you hold?

8a. If this is not the position you hold, please specify your specific job title.

9. Does your institution house a Title IX committee/board/task force?

9a. If so, please list the committee roles and accompanying salaries.

9b. Do all of these members participate in periodic training? How much does this training cost?

10. Does your institution provide sexual assault training for all faculty and staff members? What is the cost of this training?

10a. Are students required to do a sexual assault training? How much does it cost the institution to provide this training? 
11. What types of prevention strategies does your institution employ? What is the accompanying cost of each?

12. What victim services are provided by your institution? What is the accompanying cost of each?

13. How much does your institution spend on sexual assault funding annually (i.e., preventative costs, legal costs, public relations, etc.)?

13a. Out of the total amount spent on sexual assaults, how much is parceled out for "institutional support"? Institutional support is referred to as general administration services, long-range planning, legal and fiscal operations, space management, employee personnel and records, and logistical services such as development and public relations.

13b. Out of the total amount spent on sexual assaults, how much is parceled out for "student services"? Student services is referred to as student activities, cultural events, student newspapers, career guidance, counseling, financial aid administration, and student records.

14. Are you aware of how much fellow institutions within the same state are spending?

14a. Does the amount spent by institutions within the same state influence the amount your institution invests on sexual assault prevention?

14b. Do your local institutions influence you in ways other than spending?

15. Are you aware of how much institutions within your peer group are spending?

15a. Does the amount spent by your peer institutions influence the amount your institution invests on sexual assault prevention?

15b. Do your peer institutions influence you in ways other than spending?

16. Are there other influences on your institution's approach to responding to incidents of sexual assault?

17. Are there any constraints on your institution's approach to responding?

18. Do the recent changes to sexual assault court proceedings and Title IX instituted by the Trump administration impact your institutions response or cost of responding? 
Table 3:

\begin{tabular}{|c|c|c|c|c|c|c|c|c|}
\hline \multicolumn{9}{|c|}{ Student Service Expenses } \\
\hline VARIABLES & $\begin{array}{c}\text { Total Student Service } \\
\text { Expenses }\end{array}$ & $\begin{array}{c}\text { F.E. on Total } \\
\text { Student } \\
\text { Service } \\
\text { Expenses } \\
\end{array}$ & $\begin{array}{l}\text { Priv. 4-Year } \\
\text { Student } \\
\text { Service } \\
\text { Expenses } \\
\end{array}$ & $\begin{array}{l}\text { Priv. 4-Year } \\
\text { Student } \\
\text { Service } \\
\text { Expenses w/ } \\
\text { F.E. } \\
\end{array}$ & Public 4-Year & $\begin{array}{c}\text { Public 4-Year } \\
\text { F.E. }\end{array}$ & Public 2-Year & $\begin{array}{l}\text { Public 2- } \\
\text { Year F.E. }\end{array}$ \\
\hline Overall Total & $\begin{array}{c}490,251^{* * *} \\
(13,676)\end{array}$ & $\begin{array}{c}87,153^{* * *} \\
(7,095)\end{array}$ & $\begin{array}{c}618,664 * * * \\
(18,543)\end{array}$ & $\begin{array}{c}122,316^{* * * *} \\
(10,115)\end{array}$ & $\begin{array}{c}343,115^{* * *} \\
(20,398)\end{array}$ & $\begin{array}{c}32,009 * * * \\
(10,637)\end{array}$ & $\begin{array}{c}38,239 * * \\
(16,133)\end{array}$ & $\begin{array}{c}29,584 * * * \\
(11,288)\end{array}$ \\
\hline Total Expenses & $\begin{array}{c}-0.00506 * * * \\
(0.000601)\end{array}$ & $\begin{array}{l}0.0194 * * * \\
(0.000456)\end{array}$ & $\begin{array}{l}-0.00173^{* *} \\
(0.000686)\end{array}$ & $\begin{array}{l}0.0212^{* * *} \\
(0.000651)\end{array}$ & $\begin{array}{l}0.0131 * * * \\
(0.00261)\end{array}$ & $\begin{array}{l}0.0147^{* * *} \\
(0.00131)\end{array}$ & $\begin{array}{l}0.124 * * * \\
(0.00782)\end{array}$ & $\begin{array}{c}0.0779 * * * \\
(0.00611)\end{array}$ \\
\hline Total Revenue & $\begin{array}{l}0.0137^{* * *} \\
(0.000463)\end{array}$ & $\begin{array}{c}0.000531 * * * \\
(0.000197)\end{array}$ & $\begin{array}{l}0.00958^{* * *} \\
(0.000471)\end{array}$ & $\begin{array}{c}1.31 \mathrm{e}-05 \\
(0.000208)\end{array}$ & $\begin{array}{c}-0.00523 * * \\
(0.00235)\end{array}$ & $\begin{array}{c}0.00160 \\
(0.00121)\end{array}$ & $\begin{array}{c}-0.0388 * * * \\
(0.00707)\end{array}$ & $\begin{array}{c}0.00614 \\
(0.00513)\end{array}$ \\
\hline Nonresident Male & & & & & & & & \\
\hline Enrollment & $\begin{array}{c}5,899 * * * \\
(667.4)\end{array}$ & $\begin{array}{c}2,939 * * * \\
(574.2)\end{array}$ & $\begin{array}{c}14,373 * * * \\
(1,081)\end{array}$ & $\begin{array}{l}-451.8 \\
(1,035)\end{array}$ & $\begin{array}{c}2,488 * * * \\
(906.7)\end{array}$ & $\begin{array}{c}7,115^{* * *} \\
(792.5)\end{array}$ & $\begin{array}{c}10,168 * * * \\
(1,746)\end{array}$ & $\begin{array}{c}19,228 * * * \\
(1,717)\end{array}$ \\
\hline Nonresident Female & & & & & & & & \\
\hline Enrollment & $\begin{array}{c}6,417 * * * \\
(846.4)\end{array}$ & $\begin{array}{c}9,978 * * * \\
(715.9)\end{array}$ & $\begin{array}{c}-3,646 * * * \\
(1,261)\end{array}$ & $\begin{array}{c}9,957 * * * \\
(1,110)\end{array}$ & $\begin{array}{c}1,945 \\
(1,223)\end{array}$ & $\begin{array}{c}3,400 * * * \\
(1,092)\end{array}$ & $\begin{array}{c}-6,373 * * * \\
(1,745)\end{array}$ & $\begin{array}{c}-14,480 * * * \\
(1,819)\end{array}$ \\
\hline Black Male Enrollment & $\begin{array}{c}620.9 \\
(639.2)\end{array}$ & $\begin{array}{c}2,662 * * * \\
(772.2)\end{array}$ & $\begin{array}{c}4,779 * * * \\
(943.7)\end{array}$ & $\begin{array}{c}9,638 * * * \\
(1,492)\end{array}$ & $\begin{array}{l}-155.2 \\
(991.4)\end{array}$ & $\begin{array}{c}8,176 * * * \\
(1,217)\end{array}$ & $\begin{array}{l}-52.54 \\
(327.1)\end{array}$ & $\begin{array}{c}1,109 * * * \\
(419.8)\end{array}$ \\
\hline Black Female Enrollment & $\begin{array}{c}1,213 * * * \\
(331.8)\end{array}$ & $\begin{array}{c}3,056 * * * \\
(414.2)\end{array}$ & $\begin{array}{l}-251.9 \\
(483.8)\end{array}$ & $\begin{array}{c}1,356 * * \\
(661.0)\end{array}$ & $\begin{array}{c}640.6 \\
(507.5)\end{array}$ & $\begin{array}{c}-3,023^{* * *} \\
(703.2)\end{array}$ & $\begin{array}{l}-110.4 \\
(187.6)\end{array}$ & $\begin{array}{l}-570.1^{*} \\
(321.0)\end{array}$ \\
\hline Amer Indian/Alas Native & & & & & & & & \\
\hline Male Enroll & $\begin{array}{c}-16,243^{* * *} \\
(4,940)\end{array}$ & $\begin{array}{c}-16,887^{* * *} \\
(4,417)\end{array}$ & $\begin{array}{c}-67,129 * * * \\
(22,373)\end{array}$ & $\begin{array}{c}-70,866 * * * \\
(11,617)\end{array}$ & $\begin{array}{c}-24,233^{* * *} \\
(5,670)\end{array}$ & $\begin{array}{c}-11,062^{*} \\
(6,321)\end{array}$ & $\begin{array}{c}516.6 \\
(1,974)\end{array}$ & $\begin{array}{l}-3,427 \\
(2,190)\end{array}$ \\
\hline Amer Indian/Alas Native & & & & & & & & \\
\hline Female Enroll & $\begin{array}{c}7,612 * * \\
(3,037)\end{array}$ & $\begin{array}{l}-2,100 \\
(2,981)\end{array}$ & $\begin{array}{c}51,461^{* * *} \\
(14,981)\end{array}$ & $\begin{array}{c}7,711 \\
(8,873)\end{array}$ & $\begin{array}{c}10,379 * * * \\
(3,554)\end{array}$ & $\begin{array}{l}-5,543 \\
(4,247)\end{array}$ & $\begin{array}{l}-887.0 \\
(1,009)\end{array}$ & $\begin{array}{l}-229.7 \\
(1,366)\end{array}$ \\
\hline Asian Male Enrollment & $\begin{array}{c}-2,968 * * * \\
(1,031)\end{array}$ & $\begin{array}{c}1,678 \\
(1,024)\end{array}$ & $\begin{array}{c}399.7 \\
(2,537)\end{array}$ & $\begin{array}{c}-6,240 * * * \\
(2,178)\end{array}$ & $\begin{array}{c}6,690 * * * \\
(1,236)\end{array}$ & $\begin{array}{c}5,126 * * * \\
(1,293)\end{array}$ & $\begin{array}{c}-7,062^{* * *} \\
(2,145)\end{array}$ & $\begin{array}{l}-3,049 * \\
(1,712)\end{array}$ \\
\hline Asian Female Enrollment & $\begin{array}{c}7,265^{* * *} \\
(945.9)\end{array}$ & $\begin{array}{c}-2,881^{* * *} \\
(888.6)\end{array}$ & $\begin{array}{c}9,446 * * * \\
(1,973)\end{array}$ & $\begin{array}{c}4,510 * * \\
(1,910)\end{array}$ & $\begin{array}{c}108.7 \\
(1,141)\end{array}$ & $\begin{array}{c}-6,827^{* * *} \\
(1,109)\end{array}$ & $\begin{array}{c}8,065^{* * *} \\
(1,982)\end{array}$ & $\begin{array}{l}3,583^{* *} \\
(1,676)\end{array}$ \\
\hline Hispanic Male Enrollment & $\begin{array}{l}-781.9 \\
(616.3)\end{array}$ & $\begin{array}{c}2,228 * * * \\
(660.3)\end{array}$ & $\begin{array}{c}5,322 * * * \\
(1,430)\end{array}$ & $\begin{array}{c}11,179 * * * \\
(1,913)\end{array}$ & $\begin{array}{c}-2,266 * * * \\
(772.2)\end{array}$ & $\begin{array}{c}2,520 * * * \\
(905.7)\end{array}$ & $\begin{array}{c}778.9 * * * \\
(254.8)\end{array}$ & $\begin{array}{l}655.5^{* *} \\
(309.4)\end{array}$ \\
\hline Hispanic Female Enrollment & $1,732 * * *$ & $4,122 * * *$ & -710.5 & $14,865^{* * *}$ & $3,020 * * *$ & $3,289 * * *$ & -270.8 & -244.6 \\
\hline
\end{tabular}




\begin{tabular}{|c|c|c|c|c|c|c|c|c|}
\hline & $(442.5)$ & $(470.4)$ & $(926.5)$ & $(1,235)$ & $(559.6)$ & $(635.4)$ & $(189.5)$ & $(272.6)$ \\
\hline \multirow[t]{2}{*}{ White Male Enrollment } & -151.1 & $-721.1 * * *$ & $1,272 * * *$ & $-3,058 * * *$ & $1,062 * * *$ & $1,301 * * *$ & 95.12 & -212.9 \\
\hline & (153.9) & $(238.5)$ & $(264.9)$ & $(452.4)$ & $(209.2)$ & $(321.2)$ & $(121.8)$ & (196.5) \\
\hline \multirow[t]{2}{*}{ White Female Enrollment } & $1,007 * * *$ & $1,544 * * *$ & $2,014 * * *$ & $4,169 * * *$ & $289.7^{*}$ & $-1,055^{* * *}$ & -128.8 & -217.3 \\
\hline & $(130.3)$ & (183.8) & $(217.0)$ & $(307.3)$ & (174.9) & (258.9) & (92.10) & $(160.0)$ \\
\hline \multirow[t]{2}{*}{ Four-Year Institution } & 234,956 & $1.319 \mathrm{e}+06^{* *}$ & & & & & & \\
\hline & $(268,333)$ & $(592,372)$ & & & & & & \\
\hline \multirow[t]{2}{*}{ Public Institution } & $-4.279 \mathrm{e}+06 * * *$ & 42,224 & & & & & & \\
\hline & $(226,160)$ & $(1.867 e+06)$ & & & & & & \\
\hline \multirow[t]{2}{*}{ HBCU Institution } & 208,633 & & & & 790,909 & & $1.020 \mathrm{e}+06 * * *$ & \\
\hline & $(676,940)$ & & & & $(829,538)$ & & $(221,958)$ & \\
\hline \multirow[t]{2}{*}{ Constant } & $4.039 \mathrm{e}+06^{* * *}$ & $-289,569$ & $1.357 e+06 * * *$ & $691,999 * * *$ & $2.899 \mathrm{e}+06^{* * *}$ & $4.100 \mathrm{e}+06^{* * *}$ & $468,218^{* * *}$ & $959,061 * * *$ \\
\hline & $(270,827)$ & $(910,569)$ & $(128,180)$ & $(177,643)$ & $(267,921)$ & $(628,156)$ & $(56,566)$ & $(144,404)$ \\
\hline Observations & 18,545 & 18,545 & 10,993 & 10,993 & 5,047 & 5,047 & 2,188 & 2,188 \\
\hline R-squared & 0.678 & 0.959 & 0.704 & 0.962 & 0.727 & 0.961 & 0.773 & 0.934 \\
\hline
\end{tabular}

Standard errors in

parentheses

*** $\mathrm{p}<0.01, * * \mathrm{p}<0.05$, *

$p<0.1$ 
Table 4:

\begin{tabular}{|c|c|c|c|c|c|c|c|c|}
\hline \multicolumn{9}{|c|}{ Institutional Support Expenses } \\
\hline VARIABLES & Total Expenses & $\begin{array}{l}\text { F.E. on Total } \\
\text { Expenses }\end{array}$ & Private 4-year & $\begin{array}{c}\text { Private 4-year } \\
\text { F.E. } \\
\end{array}$ & Public 4-Year & $\begin{array}{c}\text { Public 4-Year } \\
\text { F.E. } \\
\end{array}$ & Public 2-Year & $\begin{array}{c}\text { Public 2-Year } \\
\text { F.E. }\end{array}$ \\
\hline \multirow[t]{2}{*}{ overall_total } & $403,956 * * *$ & $64,727 * * *$ & $641,282 * * *$ & $112,364 * * *$ & $144,758 * * *$ & 11,509 & 25,892 & 9,177 \\
\hline & $(22,850)$ & $(11,052)$ & $(29,580)$ & $(15,732)$ & $(28,797)$ & $(18,524)$ & $(27,469)$ & $(17,577)$ \\
\hline \multirow[t]{2}{*}{ expenses_total } & $0.0236 * * *$ & $0.0609 * * *$ & $0.0361 * * *$ & $0.0688 * * *$ & $0.0580 * * *$ & $0.0533^{* * *}$ & $0.171 * * *$ & $0.131 * * *$ \\
\hline & $(0.00100)$ & $(0.000710)$ & $(0.00109)$ & $(0.00101)$ & $(0.00368)$ & $(0.00229)$ & $(0.0133)$ & $(0.00951)$ \\
\hline \multirow[t]{2}{*}{ revenue_total } & $0.0216 * * *$ & $0.00183^{* * *}$ & $0.0104 * * *$ & $0.00204 * * *$ & $-0.0197 * * *$ & $4.32 \mathrm{e}-05$ & -0.00665 & $0.0213^{* * *}$ \\
\hline & $(0.000774)$ & $(0.000307)$ & $(0.000751)$ & $(0.000324)$ & $(0.00332)$ & $(0.00210)$ & $(0.0120)$ & $(0.00799)$ \\
\hline \multirow{2}{*}{ enrl_nonres_m } & $6,328 * * *$ & $-5,747 * * *$ & $24,935 * * *$ & $4,917 * * *$ & $-6,193 * * *$ & $-3,351 * *$ & $-6,001 * *$ & $-4,374$ \\
\hline & $(1,115)$ & (894.6) & $(1,725)$ & $(1,609)$ & $(1,280)$ & $(1,380)$ & $(2,972)$ & $(2,673)$ \\
\hline \multirow[t]{2}{*}{ enrl_nonres_f } & $24,356 * * *$ & $18,299 * * *$ & $-1,257$ & $6,104^{* * *}$ & $18,517^{* * *}$ & $15,205^{* * *}$ & $5,524^{*}$ & $7,069 * *$ \\
\hline & $(1,414)$ & $(1,115)$ & $(2,012)$ & $(1,726)$ & $(1,726)$ & $(1,902)$ & $(2,971)$ & $(2,832)$ \\
\hline \multirow[t]{2}{*}{ enrl_black_m } & $5,941 * * *$ & $-2,923 * *$ & $6,194 * * *$ & $-4,421^{*}$ & $5,299 * * *$ & 1,503 & -573.2 & -545.1 \\
\hline & $(1,068)$ & $(1,203)$ & $(1,505)$ & $(2,320)$ & $(1,400)$ & $(2,120)$ & (556.9) & $(653.7)$ \\
\hline \multirow[t]{2}{*}{ enrl_black_f } & $1,449 * * *$ & $4,780 * * *$ & $3,151 * * *$ & $9,019 * * *$ & -175.7 & 38.95 & -371.6 & 169.9 \\
\hline & $(554.4)$ & $(645.3)$ & $(771.8)$ & $(1,028)$ & $(716.5)$ & $(1,225)$ & (319.4) & (499.9) \\
\hline \multirow[t]{2}{*}{ enrl_amer_ind_ak_nat_m } & $-11,420$ & $-2,625$ & $200,418 * * *$ & $-76,032 * * *$ & $-42,142 * * *$ & 8,630 & $-1,229$ & 1,544 \\
\hline & $(8,253)$ & $(6,882)$ & $(35,690)$ & $(18,067)$ & $(8,004)$ & $(11,008)$ & $(3,361)$ & $(3,410)$ \\
\hline \multirow{2}{*}{ enrl_amer_ind_ak_nat_f } & 3,582 & $-6,567$ & $-126,582 * * *$ & $-14,146$ & $18,888^{* * *}$ & $-18,790 * *$ & -864.5 & -312.4 \\
\hline & $(5,074)$ & $(4,644)$ & $(23,897)$ & $(13,800)$ & $(5,017)$ & $(7,396)$ & $(1,717)$ & $(2,127)$ \\
\hline \multirow[t]{2}{*}{ enrl_asian_m } & $-24,546 * * *$ & 633.9 & $-9,247 * *$ & $9,925 * * *$ & 1,643 & 3,075 & $9,946 * * *$ & $5,457 * *$ \\
\hline & $(1,723)$ & $(1,595)$ & $(4,047)$ & $(3,387)$ & $(1,745)$ & $(2,252)$ & $(3,652)$ & $(2,665)$ \\
\hline \multirow[t]{2}{*}{ enrl_asian_f } & $18,557 * * *$ & $3,663 * * *$ & $33,921 * * *$ & $-7,386 * *$ & $-1,272$ & 1,639 & $-8,431^{* *}$ & $-3,604$ \\
\hline & $(1,580)$ & $(1,384)$ & $(3,147)$ & $(2,970)$ & $(1,611)$ & $(1,932)$ & $(3,375)$ & $(2,609)$ \\
\hline \multirow[t]{2}{*}{ enrl_hispanic_m } & $3,317^{* * *}$ & $3,741 * * *$ & $15,560 * * *$ & $23,909 * * *$ & -303.1 & $3,404 * *$ & -591.4 & 417.9 \\
\hline & $(1,030)$ & $(1,029)$ & $(2,281)$ & $(2,975)$ & $(1,090)$ & $(1,577)$ & (433.9) & (481.8) \\
\hline \multirow[t]{2}{*}{ enrl_hispanic_f } & $-1,937^{* * *}$ & 1.613 & $-8,626 * * *$ & $-1,073$ & $1,321^{*}$ & 466.6 & 277.3 & $976.6^{* *}$ \\
\hline & (739.3) & (732.8) & $(1,478)$ & $(1,921)$ & $(790.0)$ & $(1,107)$ & (322.6) & (424.5) \\
\hline \multirow[t]{2}{*}{ enrl_white_m } & $-1,022^{* * *}$ & 314.3 & $1,195 * * *$ & $-1,277^{*}$ & $1,711 * * *$ & $975.1^{*}$ & $1,120 * * *$ & 271.1 \\
\hline & (257.1) & (371.6) & $(422.5)$ & (703.6) & (295.3) & (559.4) & (207.4) & (306.0) \\
\hline \multirow[t]{2}{*}{ enrl_white_f } & 198.8 & $520.9 *$ & -441.5 & 396.6 & $-450.7^{*}$ & 199.3 & $-698.2 * * *$ & $-656.3 * * *$ \\
\hline & (217.8) & (286.3) & (346.2) & $(478.0)$ & $(247.0)$ & (450.9) & (156.8) & (249.1) \\
\hline
\end{tabular}




\begin{tabular}{|c|c|c|c|c|c|c|c|c|}
\hline inst_is_four_year & $\begin{array}{c}-1.065 e+06^{* *} \\
(448,340)\end{array}$ & $\begin{array}{c}1.060 \mathrm{e}+06 \\
(922,833)\end{array}$ & & & & & & \\
\hline inst_is_public & $\begin{array}{c}- \\
5.343 e+06 * * * \\
(377,876) \\
-\end{array}$ & $\begin{array}{c}147,736 \\
(2.908 e+06)\end{array}$ & & & & & & \\
\hline inst_is_hbcu & $\begin{array}{c}4.578 \mathrm{e}+06 * * * \\
(1.131 \mathrm{e}+06)\end{array}$ & & & & $\begin{array}{c}-1.313 e+06 \\
(1.171 e+06)\end{array}$ & & $\begin{array}{c}1.523 e+06 * * * \\
(377,902)\end{array}$ & \\
\hline Constant & $\begin{array}{c}6.779 \mathrm{e}+06^{* * *} \\
(452,508)\end{array}$ & $\begin{array}{c}288,387 \\
(1.419 e+06)\end{array}$ & $\begin{array}{c}1.684 \mathrm{e}+06^{* * *} \\
(204,473)\end{array}$ & $\begin{array}{c}4.091 \mathrm{e}+06 * * * \\
(276,277)\end{array}$ & $\begin{array}{c}4.328 \mathrm{e}+06 * * * \\
(378,232)\end{array}$ & $\begin{array}{c}2.668 \mathrm{e}+06 * * \\
(1.094 \mathrm{e}+06)\end{array}$ & $\begin{array}{c}-276,216^{* * *} \\
(96,309)\end{array}$ & $\begin{array}{c}205,750 \\
(224,854)\end{array}$ \\
\hline Observations & 18,545 & 18,545 & 10,993 & 10,993 & 5,047 & 5,047 & 2,188 & 2,188 \\
\hline R-squared & 0.772 & 0.975 & 0.834 & 0.980 & 0.824 & 0.962 & 0.775 & 0.946 \\
\hline
\end{tabular}

Standard errors in

parentheses

*** $\mathrm{p}<0.01,{ }^{* *} \mathrm{p}<0.05, *$

$p<0.1$ 
Table 5:

\begin{tabular}{|c|c|c|c|c|c|c|c|c|}
\hline \multicolumn{9}{|c|}{ Student Service \& Institutional Support Expenses Before \& After the DCL in 2011} \\
\hline VARIABLES & $\begin{array}{c}\text { Student Services } \\
\text { Before } 2011 \\
\end{array}$ & $\begin{array}{c}\text { Student } \\
\text { Services Before } \\
2011 \text { with F.E. }\end{array}$ & $\begin{array}{c}\text { Institutional } \\
\text { Support Before } \\
2011 \\
\end{array}$ & $\begin{array}{c}\text { Institutional } \\
\text { Support } \\
\text { Before } 2011 \\
\text { with F.E. } \\
\end{array}$ & $\begin{array}{c}\text { Student Services } \\
\text { After } 2011 \\
\end{array}$ & $\begin{array}{c}\text { Student } \\
\text { Services After } \\
2011 \text { with F.E. }\end{array}$ & $\begin{array}{c}\text { Institutional } \\
\text { Support After } \\
2011 \\
\end{array}$ & 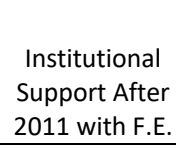 \\
\hline Overall Total & $\begin{array}{c}410,943 * * * \\
(29,749)\end{array}$ & $\begin{array}{l}-11,032 \\
(11,880)\end{array}$ & $\begin{array}{c}447,931 * * * \\
(51,279)\end{array}$ & $\begin{array}{c}18,262 \\
(26,043)\end{array}$ & $\begin{array}{c}302,128 * * * \\
(19,549)\end{array}$ & $\begin{array}{c}19,410^{* *} \\
(8,289)\end{array}$ & $\begin{array}{c}224,354 * * * \\
(32,021)\end{array}$ & $\begin{array}{c}-1,035 \\
(13,264)\end{array}$ \\
\hline Total Expenses & $\begin{array}{c}0.00329 * * * \\
(0.000770)\end{array}$ & $\begin{array}{l}0.0178 * * * \\
(0.000649)\end{array}$ & $\begin{array}{c}0.0410 * * * \\
(0.00133)\end{array}$ & $\begin{array}{c}0.0553 * * * \\
(0.00142)\end{array}$ & $\begin{array}{c}-0.0282 * * * \\
(0.00121)\end{array}$ & $\begin{array}{l}0.0110 * * * \\
(0.000977)\end{array}$ & $\begin{array}{c}-0.0250 * * * \\
(0.00199)\end{array}$ & $\begin{array}{c}0.0643 * * * \\
(0.00156)\end{array}$ \\
\hline Total Revenue & $\begin{array}{c}0.00656 * * * \\
(0.000502)\end{array}$ & $\begin{array}{c}- \\
0.000550 * * * \\
(0.000139)\end{array}$ & $\begin{array}{c}0.00556 * * * \\
(0.000864)\end{array}$ & $\begin{array}{c}0.000714 * * \\
(0.000305)\end{array}$ & $\begin{array}{l}0.0330 * * * \\
(0.000992)\end{array}$ & $\begin{array}{c}- \\
0.000972 * * \\
(0.000401)\end{array}$ & $\begin{array}{c}0.0624 * * * \\
(0.00163)\end{array}$ & $\begin{array}{l}-0.000888 \\
(0.000642)\end{array}$ \\
\hline Nonresident Male Enrollment & $\begin{array}{c}3,655^{* * *} \\
(1,150)\end{array}$ & $\begin{array}{c}8,609 * * * \\
(1,069)\end{array}$ & $\begin{array}{c}15,848 * * * \\
(1,982)\end{array}$ & $\begin{array}{c}455.8 \\
(2,344)\end{array}$ & $\begin{array}{c}3,511 * * * \\
(914.5)\end{array}$ & $\begin{array}{l}-538.6 \\
(827.0)\end{array}$ & $\begin{array}{l}-1,407 \\
(1,498)\end{array}$ & $\begin{array}{c}-3,667 * * * \\
(1,323)\end{array}$ \\
\hline Nonresident Female Enrollment & $\begin{array}{c}6,443^{* * *} \\
(1,510)\end{array}$ & $\begin{array}{c}2,427^{* *} \\
(1,170)\end{array}$ & $\begin{array}{c}20,507^{* * *} \\
(2,604)\end{array}$ & $\begin{array}{c}14,876^{* * *} \\
(2,565)\end{array}$ & $\begin{array}{c}6,294^{* * *} \\
(1,142)\end{array}$ & $\begin{array}{c}6,846 * * * \\
(1,108)\end{array}$ & $\begin{array}{c}29,191 * * * \\
(1,871)\end{array}$ & $\begin{array}{c}8,897 * * * \\
(1,773)\end{array}$ \\
\hline Black Male Enrollment & $\begin{array}{l}1,539 * \\
(883.8)\end{array}$ & $\begin{array}{c}574.3 \\
(1,110)\end{array}$ & $\begin{array}{c}5,782^{* * *} \\
(1,524)\end{array}$ & $\begin{array}{c}-6,145^{* *} \\
(2,433)\end{array}$ & $\begin{array}{l}-758.8 \\
(1,077)\end{array}$ & $\begin{array}{c}5,670 * * * \\
(1,592)\end{array}$ & $\begin{array}{c}6,656 * * * \\
(1,764)\end{array}$ & $\begin{array}{l}-3,197 \\
(2,548)\end{array}$ \\
\hline Black Female Enrollment & $\begin{array}{l}-309.5 \\
(446.4)\end{array}$ & $\begin{array}{c}856.0 \\
(557.9)\end{array}$ & $\begin{array}{c}285.2 \\
(769.5)\end{array}$ & $\begin{array}{c}3,496 * * * \\
(1,223)\end{array}$ & $\begin{array}{c}2,188^{* * *} \\
(552.9)\end{array}$ & $\begin{array}{c}792.5 \\
(781.8)\end{array}$ & $\begin{array}{c}1,939 * * \\
(905.6)\end{array}$ & $\begin{array}{c}2,879 * * \\
(1,251)\end{array}$ \\
\hline $\begin{array}{l}\text { Amer Indian/Alas Native Male } \\
\text { Enroll }\end{array}$ & $\begin{array}{l}-9,328 \\
(6,472)\end{array}$ & $\begin{array}{c}-11,863^{* *} \\
(5,654)\end{array}$ & $\begin{array}{c}-435.9 \\
(11,156)\end{array}$ & $\begin{array}{c}10,092 \\
(12,394)\end{array}$ & $\begin{array}{c}-14,487 \\
(9,423)\end{array}$ & $\begin{array}{c}978.9 \\
(7,834)\end{array}$ & $\begin{array}{l}-15,409 \\
(15,435)\end{array}$ & $\begin{array}{c}8,768 \\
(12,536)\end{array}$ \\
\hline $\begin{array}{l}\text { Amer Indian/Alas Native Female } \\
\text { Enroll }\end{array}$ & $\begin{array}{c}4,218 \\
(4,120)\end{array}$ & $\begin{array}{c}579.9 \\
(3,648)\end{array}$ & $\begin{array}{l}-3,209 \\
(7,101)\end{array}$ & $\begin{array}{l}-10,817 \\
(7,997)\end{array}$ & $\begin{array}{c}10,855^{*} \\
(5,819)\end{array}$ & $\begin{array}{l}-8,940 \\
(5,511)\end{array}$ & $\begin{array}{l}10,281 \\
(9,532)\end{array}$ & $\begin{array}{c}-16,812^{*} \\
(8,819)\end{array}$ \\
\hline Asian Male Enrollment & $\begin{array}{c}-4,082^{* * *} \\
(1,448)\end{array}$ & $\begin{array}{c}2,791 * * \\
(1,236)\end{array}$ & $\begin{array}{c}-22,768 * * * \\
(2,496)\end{array}$ & $\begin{array}{c}1,936 \\
(2,709)\end{array}$ & $\begin{array}{c}-2,735^{*} \\
(1,597)\end{array}$ & $\begin{array}{l}-1,205 \\
(1,704)\end{array}$ & $\begin{array}{c}-28,907 * * * \\
(2,616)\end{array}$ & $\begin{array}{c}5,639 * * \\
(2,726)\end{array}$ \\
\hline Asian Female Enrollment & $\begin{array}{c}6,027^{* * *} \\
(1,285)\end{array}$ & $\begin{array}{l}-1,531 \\
(1,068)\end{array}$ & $\begin{array}{c}13,436 * * * \\
(2,216)\end{array}$ & $\begin{array}{l}4,118^{*} \\
(2,341)\end{array}$ & $\begin{array}{c}10,309 * * * \\
(1,519)\end{array}$ & $\begin{array}{c}-8,732^{* * *} \\
(1,681)\end{array}$ & $\begin{array}{c}25,991 * * * \\
(2,488)\end{array}$ & $\begin{array}{l}-4,986^{*} \\
(2,690)\end{array}$ \\
\hline Hispanic Male Enrollment & $\begin{array}{l}-693.1 \\
(966.3)\end{array}$ & $\begin{array}{c}3,240 * * * \\
(1,071)\end{array}$ & $\begin{array}{c}946.4 \\
(1,666)\end{array}$ & $\begin{array}{c}7,148 * * * \\
(2,347)\end{array}$ & $\begin{array}{l}-852.7 \\
(987.7)\end{array}$ & $\begin{array}{c}1,124 \\
(1,612)\end{array}$ & $\begin{array}{c}7,695^{* * *} \\
(1,618)\end{array}$ & $\begin{array}{l}4,277^{*} \\
(2,579)\end{array}$ \\
\hline Hispanic Female Enrollment & $\begin{array}{c}1,075 \\
(658.8)\end{array}$ & $\begin{array}{c}1,787^{* *} \\
(725.9)\end{array}$ & $\begin{array}{l}-371.8 \\
(1,136)\end{array}$ & $\begin{array}{l}-1,679 \\
(1,591)\end{array}$ & $\begin{array}{c}1,670 * * \\
(732.4)\end{array}$ & $\begin{array}{l}1,941^{*} \\
(1,114)\end{array}$ & $\begin{array}{c}-5,690 * * * \\
(1,200)\end{array}$ & $\begin{array}{l}-33.82 \\
(1,783)\end{array}$ \\
\hline
\end{tabular}




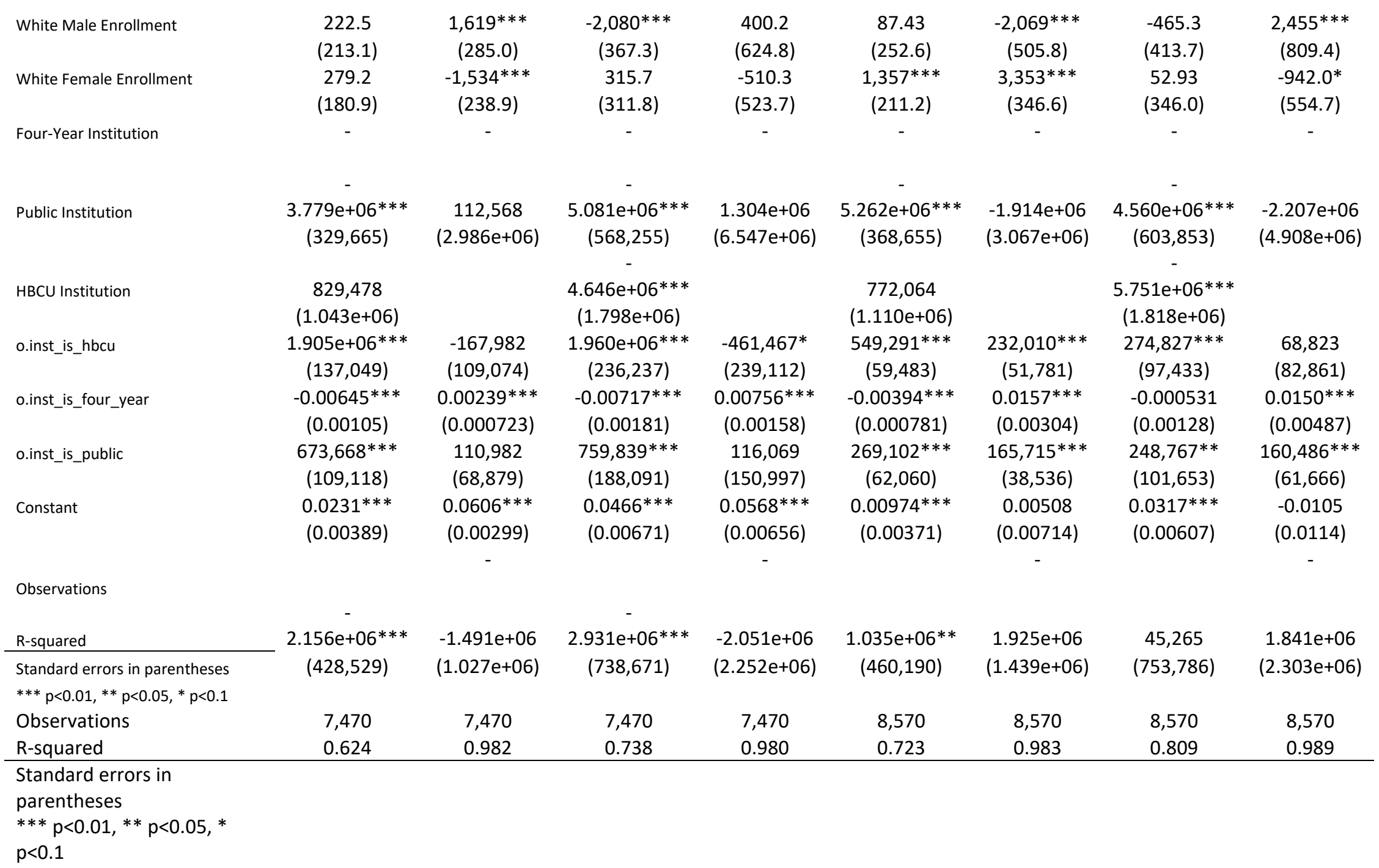


Table 6:

\begin{tabular}{|c|c|c|c|c|c|c|c|c|}
\hline & & & Student Servic & Expenses & & & & \\
\hline VARIABLES & $\begin{array}{l}\text { Total Student } \\
\text { Service Expenses }\end{array}$ & $\begin{array}{l}\text { F.E. on Total } \\
\text { Student Service } \\
\text { Expenses }\end{array}$ & $\begin{array}{l}\text { Priv. 4-Year } \\
\text { Student Service } \\
\text { Expenses }\end{array}$ & $\begin{array}{c}\text { Priv. 4-Year } \\
\text { Student Service } \\
\text { Expenses w/ F.E. }\end{array}$ & $\begin{array}{l}\text { Public 4-Year } \\
229,746^{* *}\end{array}$ & Public 4-Year F.E. & Public 2-Year & $\begin{array}{l}\text { Public 2-Year } \\
\text { F.E. }\end{array}$ \\
\hline Overall Total & $\begin{array}{c}364,604 * * * \\
(14,903)\end{array}$ & $\begin{array}{c}23,488^{* * *} \\
(7,420)\end{array}$ & $\begin{array}{c}503,213 * * * \\
(20,033)\end{array}$ & $\begin{array}{c}64,759 * * * \\
(10,765)\end{array}$ & $\begin{array}{c}* \\
(22,718)\end{array}$ & $\begin{array}{c}-3,979 \\
(11,058)\end{array}$ & $\begin{array}{c}22,161 \\
(16,269)\end{array}$ & $\begin{array}{c}23,245^{* *} \\
(11,147)\end{array}$ \\
\hline Total Expenses & $\begin{array}{c}-0.00567^{* * *} \\
(0.000604)\end{array}$ & $\begin{array}{l}0.0167^{* * *} \\
(0.000463)\end{array}$ & $\begin{array}{c}-0.00449 * * * \\
(0.000706)\end{array}$ & $\begin{array}{l}0.0183 * * * \\
(0.000711)\end{array}$ & $\begin{array}{c}0.0116 * * * \\
(0.00260)\end{array}$ & $\begin{array}{c}0.0114 * * * \\
(0.00127)\end{array}$ & $\begin{array}{l}0.111 * * * \\
(0.00792)\end{array}$ & $\begin{array}{c}0.0572 * * * \\
(0.00619)\end{array}$ \\
\hline Total Revenue & $\begin{array}{l}0.0139 * * * \\
(0.000458)\end{array}$ & $\begin{array}{c}0.000497^{* * *} \\
(0.000192)\end{array}$ & $\begin{array}{c}0.00935^{* * *} \\
(0.000464)\end{array}$ & $\begin{array}{c}-5.01 \mathrm{e}-05 \\
(0.000206)\end{array}$ & $\begin{array}{l}-0.00333 \\
(0.00234)\end{array}$ & $\begin{array}{l}0.00197^{*} \\
(0.00115)\end{array}$ & $\begin{array}{c}-0.0336^{* * *} \\
(0.00703)\end{array}$ & $\begin{array}{l}0.000503 \\
(0.00501)\end{array}$ \\
\hline Nonresident Male Enrollment & $\begin{array}{c}4,477^{* * *} \\
(664.8)\end{array}$ & $\begin{array}{l}995.0^{*} \\
(565.2)\end{array}$ & $\begin{array}{c}12,704^{* * *} \\
(1,068)\end{array}$ & $\begin{array}{c}-1,774^{*} \\
(1,025)\end{array}$ & $\begin{array}{c}440.4 \\
(914.5)\end{array}$ & $\begin{array}{c}4,751 * * * \\
(778.2)\end{array}$ & $\begin{array}{c}9,929 * * * \\
(1,733)\end{array}$ & $\begin{array}{c}19,075^{* * *} \\
(1,674)\end{array}$ \\
\hline Nonresident Female Enrollment & $\begin{array}{c}6,496 * * * \\
(836.4)\end{array}$ & $\begin{array}{c}10,240^{* * *} \\
(695.2)\end{array}$ & $\begin{array}{c}-4,552^{* * *} \\
(1,242)\end{array}$ & $\begin{array}{c}9,759 * * * \\
(1,101)\end{array}$ & $\begin{array}{c}3,514 * * * \\
(1,213)\end{array}$ & $\begin{array}{c}4,801 * * * \\
(1,050)\end{array}$ & $\begin{array}{c}-5,834 * * * \\
(1,736)\end{array}$ & $\begin{array}{c}-15,315^{* * *} \\
(1,768)\end{array}$ \\
\hline Black Male Enrollment & $\begin{array}{c}296.8 \\
(632.8)\end{array}$ & $\begin{array}{l}-1,217 \\
(760.3)\end{array}$ & $\begin{array}{c}4,872 * * * \\
(933.2)\end{array}$ & $\begin{array}{c}5,817^{* * *} \\
(1,487)\end{array}$ & $\begin{array}{l}-879.0 \\
(982.7)\end{array}$ & $\begin{array}{c}3,283^{* * *} \\
(1,194)\end{array}$ & $\begin{array}{l}-289.8 \\
(325.9)\end{array}$ & $\begin{array}{c}626.0 \\
(410.7)\end{array}$ \\
\hline Black Female Enrollment & $\begin{array}{c}1,150 * * * \\
(328.5)\end{array}$ & $\begin{array}{c}4,440 * * * \\
(404.9)\end{array}$ & $\begin{array}{l}-386.1 \\
(476.9)\end{array}$ & $\begin{array}{c}2,232 * * * \\
(653.2)\end{array}$ & $\begin{array}{l}850.6^{*} \\
(505.4)\end{array}$ & $\begin{array}{l}-1,036 \\
(683.0)\end{array}$ & $\begin{array}{c}181.9 \\
(189.3)\end{array}$ & $\begin{array}{l}-176.3 \\
(313.9)\end{array}$ \\
\hline Amer Indian/Alas Native Male Enroll & $\begin{array}{c}-12,052^{* *} \\
(4,884)\end{array}$ & $\begin{array}{c}-13,098^{* * *} \\
(4,296)\end{array}$ & $\begin{array}{c}-56,123^{* *} \\
(22,020)\end{array}$ & $\begin{array}{c}-72,244^{* * *} \\
(11,463)\end{array}$ & $\begin{array}{c}-20,716^{* * *} \\
(5,615)\end{array}$ & $\begin{array}{l}-3,513 \\
(6,062)\end{array}$ & $\begin{array}{l}-75.57 \\
(1,972)\end{array}$ & $\begin{array}{l}-3,454 \\
(2,117)\end{array}$ \\
\hline $\begin{array}{l}\text { Amer Indian/Alas Native Female } \\
\text { Enroll }\end{array}$ & $\begin{array}{c}6,583 * * \\
(3,001)\end{array}$ & $\begin{array}{l}-1,907 \\
(2,892)\end{array}$ & $\begin{array}{c}50,835^{* * *} \\
(14,741)\end{array}$ & $\begin{array}{c}9,276 \\
(8,744)\end{array}$ & $\begin{array}{c}9,920 * * * \\
(3,511)\end{array}$ & $\begin{array}{l}-6,807 * \\
(4,061)\end{array}$ & $\begin{array}{l}-615.4 \\
(998.3)\end{array}$ & $\begin{array}{c}173.7 \\
(1,322)\end{array}$ \\
\hline Asian Male Enrollment & $\begin{array}{c}-2,584^{* *} \\
(1,020)\end{array}$ & $\begin{array}{c}2,977 * * * \\
(995.5)\end{array}$ & $\begin{array}{l}-1,339 \\
(2,511)\end{array}$ & $\begin{array}{l}-4,102^{*} \\
(2,150)\end{array}$ & $\begin{array}{c}7,554^{* * *} \\
(1,226)\end{array}$ & $\begin{array}{c}4,996 * * * \\
(1,240)\end{array}$ & $\begin{array}{c}-7,092^{* * *} \\
(2,120)\end{array}$ & $\begin{array}{l}-2,878^{*} \\
(1,659)\end{array}$ \\
\hline Asian Female Enrollment & $\begin{array}{c}7,014^{* * *} \\
(934.8)\end{array}$ & $\begin{array}{c}-4,761^{* * *} \\
(865.5)\end{array}$ & $\begin{array}{c}10,996^{* * *} \\
(1,954)\end{array}$ & $\begin{array}{c}2,108 \\
(1,891)\end{array}$ & $\begin{array}{l}-495.6 \\
(1,127)\end{array}$ & $\begin{array}{c}-7,284 * * * \\
(1,067)\end{array}$ & $\begin{array}{c}8,360 * * * \\
(1,963)\end{array}$ & $\begin{array}{c}3,834^{* *} \\
(1,621)\end{array}$ \\
\hline Hispanic Male Enrollment & $\begin{array}{c}-659.4 \\
(609.3)\end{array}$ & $\begin{array}{c}1,781^{* * *} \\
(643.9)\end{array}$ & $\begin{array}{c}6,476^{* * *} \\
(1,412)\end{array}$ & $\begin{array}{c}7,671^{* * *} \\
(1,903)\end{array}$ & $\begin{array}{c}-2,413^{* * *} \\
(765.7)\end{array}$ & $\begin{array}{l}1,523^{*} \\
(870.7)\end{array}$ & $\begin{array}{c}714.1^{* * *} \\
(252.5)\end{array}$ & $\begin{array}{c}778.0^{* * *} \\
(299.1)\end{array}$ \\
\hline Hispanic Female Enrollment & $\begin{array}{c}1,440 * * * \\
(438.0)\end{array}$ & $\begin{array}{c}3,217 * * * \\
(459.3)\end{array}$ & $\begin{array}{l}-1,649 * \\
(915.1)\end{array}$ & $\begin{array}{c}13,988^{* * *} \\
(1,236)\end{array}$ & $\begin{array}{c}2,954^{* * *} \\
(555.5)\end{array}$ & $\begin{array}{c}2,690 * * * \\
(611.7)\end{array}$ & $\begin{array}{c}-195.1 \\
(187.7)\end{array}$ & $\begin{array}{l}-486.6^{*} \\
(266.3)\end{array}$ \\
\hline
\end{tabular}




\begin{tabular}{|c|c|c|c|c|c|c|c|c|}
\hline White Male Enrollment & $\begin{array}{l}-92.61 \\
(156.1)\end{array}$ & $\begin{array}{c}-475.1 * * \\
(232.2)\end{array}$ & $\begin{array}{c}1,154 * * * \\
(263.8)\end{array}$ & $\begin{array}{c}-2,240 * * * \\
(449.0)\end{array}$ & $\begin{array}{c}1,385^{* * *} \\
(216.8)\end{array}$ & $\begin{array}{c}1,145^{* * *} \\
(309.9)\end{array}$ & $\begin{array}{c}152.9 \\
(122.1)\end{array}$ & $\begin{array}{l}-208.0 \\
(190.2)\end{array}$ \\
\hline White Female Enrollment & $\begin{array}{c}979.4^{* * *} \\
(130.3)\end{array}$ & $\begin{array}{c}1,647^{* * *} \\
(178.6)\end{array}$ & $\begin{array}{c}2,009 * * * \\
(217.5)\end{array}$ & $\begin{array}{c}4,245^{* * *} \\
(303.6)\end{array}$ & $\begin{array}{c}180.7 \\
(175.9)\end{array}$ & $\begin{array}{c}-794.9 * * * \\
(249.5)\end{array}$ & $\begin{array}{l}-94.21 \\
(92.64)\end{array}$ & $\begin{array}{l}-118.0 \\
(155.6)\end{array}$ \\
\hline Four-Year Institution & $\begin{array}{c}-749,541 * * * \\
(273,539) \\
- \\
4.206 \mathrm{e}+06 * * \\
* \\
(225,108)\end{array}$ & $\begin{array}{c}200,235 \\
(576,483)\end{array}$ & & & & & . & \\
\hline HBCU Institution & $\begin{array}{c}474,371 \\
(669,037)\end{array}$ & & & & $\begin{array}{c}1.314 \mathrm{e}+06 \\
(819,644) \\
619,582 * *\end{array}$ & & $\begin{array}{c}1.010 e+06 * * \\
* \\
(219,111)\end{array}$ & \\
\hline Overall Total by Type & $\begin{array}{c}549,616 * * * \\
(43,376)\end{array}$ & $\begin{array}{c}279,392 * * * \\
(25,703)\end{array}$ & $\begin{array}{c}280,458 * * * \\
(57,023)\end{array}$ & $\begin{array}{c}318,611 * * * \\
(38,220)\end{array}$ & $\begin{array}{c}* \\
(69,900) \\
- \\
0.00546^{* *}\end{array}$ & $\begin{array}{c}168,669 * * * \\
(39,131)\end{array}$ & $\begin{array}{l}-135,241 \\
(118,109)\end{array}$ & $\begin{array}{l}133,529 \\
(90,759)\end{array}$ \\
\hline Expenses Total by Type & $\begin{array}{c}-0.00174 * * * \\
(0.000534)\end{array}$ & $\begin{array}{l}0.00122 * * \\
(0.000564)\end{array}$ & $\begin{array}{c}0.00667 * * * \\
(0.000789)\end{array}$ & $\begin{array}{c}0.00452 * * * \\
(0.00129)\end{array}$ & $\begin{array}{c}* \\
(0.000791) \\
243,904 * *\end{array}$ & $\begin{array}{c}0.00107 \\
(0.000708)\end{array}$ & $\begin{array}{c}0.0184 * * * \\
(0.00508)\end{array}$ & $\begin{array}{c}0.0325 * * * \\
(0.00604)\end{array}$ \\
\hline Overall Total by State & $\begin{array}{c}266,692^{* * *} \\
(44,600)\end{array}$ & $\begin{array}{c}-3,321 \\
(27,876)\end{array}$ & $\begin{array}{c}257,613 * * * \\
(53,877)\end{array}$ & $\begin{array}{l}-56,015 \\
(34,833)\end{array}$ & $\begin{array}{c}* \\
(94,078)\end{array}$ & $\begin{array}{c}-118,007^{*} \\
(61,960)\end{array}$ & $\begin{array}{c}100,758 * * * \\
(23,095)\end{array}$ & $\begin{array}{l}-41,093^{*} \\
(21,548)\end{array}$ \\
\hline Expenses Total by State & $\begin{array}{c}0.0137 * * * \\
(0.00232)\end{array}$ & $\begin{array}{c}0.0431 * * * \\
(0.00243)\end{array}$ & $\begin{array}{c}0.0132 * * * \\
(0.00304)\end{array}$ & $\begin{array}{c}0.0186 * * * \\
(0.00307)\end{array}$ & $\begin{array}{l}0.0107^{* *} \\
(0.00441)\end{array}$ & $\begin{array}{c}0.0848 * * * \\
(0.00529)\end{array}$ & $\begin{array}{c}0.000885 \\
(0.000868)\end{array}$ & $\begin{array}{l}0.00510 * \\
(0.00264)\end{array}$ \\
\hline & & - & - & - & - & - & - & - \\
\hline Constant & $\begin{array}{c}1.639 \mathrm{e}+06 * * \\
* \\
(350,016)\end{array}$ & $\begin{array}{c}3.903 e+06 * * \\
* \\
(901,538)\end{array}$ & $\begin{array}{c}1.761 \mathrm{e}+06 * * \\
* \\
(315,034)\end{array}$ & $\begin{array}{c}2.009 e+06 * * \\
* \\
(330,648)\end{array}$ & $\begin{array}{l}-408,670 \\
(494,059)\end{array}$ & $\begin{array}{c}3.141 \mathrm{e}+06 * * \\
* \\
(717,513)\end{array}$ & $\begin{array}{c}-554,032 * * * \\
(210,406)\end{array}$ & $\begin{array}{l}-317,201^{*} \\
(177,656)\end{array}$ \\
\hline Observations & 18,545 & 18,545 & 10,993 & 10,993 & 5,047 & 5,047 & 2,188 & 2,188 \\
\hline R-squared & 0.686 & 0.961 & 0.713 & 0.963 & 0.735 & 0.964 & 0.779 & 0.939 \\
\hline
\end{tabular}

Standard errors in parentheses

${ }^{* * *} p<0.01,{ }^{* *} p<0.05,{ }^{*} p<0.1$ 
Table 7:

Institutional Support

\begin{tabular}{|c|c|c|c|c|c|c|c|c|}
\hline \multicolumn{9}{|c|}{ Institutional Support } \\
\hline VARIABLES & $\begin{array}{l}\text { Total Institutional } \\
\text { Support Expenses }\end{array}$ & $\begin{array}{l}\text { F.E. on Total } \\
\text { Institutional } \\
\text { Support } \\
\text { Expenses }\end{array}$ & $\begin{array}{l}\text { Priv. 4-Year } \\
\text { Institutional } \\
\text { Support } \\
\text { Expenses }\end{array}$ & $\begin{array}{c}\text { Priv. 4-Year } \\
\text { Institutional } \\
\text { Support Expenses } \\
\text { w/F.E. }\end{array}$ & Public 4-Year & Public 4-Year F.E. & Public 2-Year & Public 2-Year F.E. \\
\hline Overall Total & $\begin{array}{c}343,523 * * * \\
(25,114)\end{array}$ & $\begin{array}{c}25,923 * * \\
(11,857)\end{array}$ & $\begin{array}{c}645,348 * * * \\
(32,391)\end{array}$ & $\begin{array}{c}117,046^{* * *} \\
(16,990)\end{array}$ & $\begin{array}{c}10,600 \\
(32,183)\end{array}$ & $\begin{array}{c}-45,742^{* *} \\
(19,921)\end{array}$ & $\begin{array}{c}6,311 \\
(27,885)\end{array}$ & $\begin{array}{c}-1,988 \\
(17,580)\end{array}$ \\
\hline Total Expenses & $\begin{array}{c}0.0226 * * * \\
(0.00102)\end{array}$ & $\begin{array}{l}0.0590 * * * \\
(0.000740)\end{array}$ & $\begin{array}{c}0.0347^{* * *} \\
(0.00114)\end{array}$ & $\begin{array}{c}0.0688^{* * *} \\
(0.00112)\end{array}$ & $\begin{array}{c}0.0559 * * * \\
(0.00369)\end{array}$ & $\begin{array}{c}0.0500 * * * \\
(0.00228)\end{array}$ & $\begin{array}{c}0.154^{* * *} \\
(0.0136)\end{array}$ & $\begin{array}{l}0.103^{* * *} \\
(0.00976)\end{array}$ \\
\hline Total Revenue & $\begin{array}{l}0.0216^{* * *} \\
(0.000772)\end{array}$ & $\begin{array}{l}0.00184^{* * *} \\
(0.000306)\end{array}$ & $\begin{array}{l}0.0103 * * * \\
(0.000750)\end{array}$ & $\begin{array}{c}0.00209 * * * \\
(0.000325)\end{array}$ & $\begin{array}{c}-0.0177^{* * *} \\
(0.00332)\end{array}$ & $\begin{array}{l}0.000456 \\
(0.00208)\end{array}$ & $\begin{array}{c}-0.000575 \\
(0.0120)\end{array}$ & $\begin{array}{l}0.0170 * * \\
(0.00790)\end{array}$ \\
\hline Nonresident Male Enrollment & $\begin{array}{c}5,853^{* * *} \\
(1,120)\end{array}$ & $\begin{array}{c}-6,832^{* * *} \\
(903.1)\end{array}$ & $\begin{array}{c}24,586^{* * *} \\
(1,727)\end{array}$ & $\begin{array}{c}4,969 * * * \\
(1,618)\end{array}$ & $\begin{array}{c}-7,693^{* * *} \\
(1,296)\end{array}$ & $\begin{array}{c}-5,897 * * * \\
(1,402)\end{array}$ & $\begin{array}{c}-6,664^{* *} \\
(2,971)\end{array}$ & $\begin{array}{l}-4,324 \\
(2,640)\end{array}$ \\
\hline Nonresident Female Enrollment & $\begin{array}{c}24,145^{* * *} \\
(1,409)\end{array}$ & $\begin{array}{c}18,351^{* * *} \\
(1,111)\end{array}$ & $\begin{array}{c}-1,393 \\
(2,008)\end{array}$ & $\begin{array}{c}6,230 * * * \\
(1,738)\end{array}$ & $\begin{array}{c}19,967^{* * *} \\
(1,719)\end{array}$ & $\begin{array}{c}16,693^{* * *} \\
(1,891)\end{array}$ & $\begin{array}{r}6,588^{* *} \\
(2,976)\end{array}$ & $\begin{array}{c}5,699 * * \\
(2,789)\end{array}$ \\
\hline Black Male Enrollment & $\begin{array}{c}6,048^{* * *} \\
(1,066)\end{array}$ & $\begin{array}{c}-5,568^{* * *} \\
(1,215)\end{array}$ & $\begin{array}{c}6,984^{* * *} \\
(1,509)\end{array}$ & $\begin{array}{c}-4,776^{* *} \\
(2,347)\end{array}$ & $\begin{array}{c}4,763 * * * \\
(1,392)\end{array}$ & $\begin{array}{l}-3,280 \\
(2,150)\end{array}$ & $\begin{array}{l}-917.2 \\
(558.6)\end{array}$ & $\begin{array}{l}-1,244^{*} \\
(647.8)\end{array}$ \\
\hline Black Female Enrollment & $\begin{array}{c}1,267^{* *} \\
(553.6)\end{array}$ & $\begin{array}{c}5,702 * * * \\
(647.0)\end{array}$ & $\begin{array}{c}2,809 * * * \\
(771.1)\end{array}$ & $\begin{array}{c}9,059 * * * \\
(1,031)\end{array}$ & $\begin{array}{c}43.96 \\
(716.0)\end{array}$ & $\begin{array}{l}2,257^{*} \\
(1,231)\end{array}$ & $\begin{array}{l}-13.66 \\
(324.5)\end{array}$ & $\begin{array}{c}683.5 \\
(495.1)\end{array}$ \\
\hline $\begin{array}{l}\text { Amer Indian/Alas Native Male } \\
\text { Enroll }\end{array}$ & $\begin{array}{l}-6,626 \\
(8,231)\end{array}$ & $\begin{array}{c}386.7 \\
(6,865)\end{array}$ & $\begin{array}{c}205,306 * * * \\
(35,604)\end{array}$ & $\begin{array}{c}-76,910 * * * \\
(18,091)\end{array}$ & $\begin{array}{c}-35,327 * * * \\
(7,954)\end{array}$ & $\begin{array}{c}17,882 \\
(10,921)\end{array}$ & $\begin{array}{l}-1,709 \\
(3,381)\end{array}$ & $\begin{array}{c}1,082 \\
(3,339)\end{array}$ \\
\hline $\begin{array}{l}\text { Amer Indian/Alas Native Female } \\
\text { Enroll }\end{array}$ & $\begin{array}{c}2,197 \\
(5,057)\end{array}$ & $\begin{array}{l}-6,700 \\
(4,621)\end{array}$ & $\begin{array}{c}-124,737^{* * *} \\
(23,834)\end{array}$ & $\begin{array}{l}-13,771 \\
(13,799)\end{array}$ & $\begin{array}{c}17,122^{* * *} \\
(4,974)\end{array}$ & $\begin{array}{c}-21,155^{* * *} \\
(7,317)\end{array}$ & $\begin{array}{l}-578.0 \\
(1,711)\end{array}$ & $\begin{array}{c}362.0 \\
(2,085)\end{array}$ \\
\hline Asian Male Enrollment & $\begin{array}{c}-24,650^{* * *} \\
(1,718)\end{array}$ & $\begin{array}{c}1,308 \\
(1,591)\end{array}$ & $\begin{array}{c}-10,113^{* *} \\
(4,060)\end{array}$ & $\begin{array}{c}9,990 * * * \\
(3,392)\end{array}$ & $\begin{array}{c}1,614 \\
(1,737)\end{array}$ & $\begin{array}{c}3,440 \\
(2,234)\end{array}$ & $\begin{array}{c}9,727^{* * *} \\
(3,634)\end{array}$ & $\begin{array}{l}5,240 * * \\
(2,616)\end{array}$ \\
\hline Asian Female Enrollment & $\begin{array}{c}18,278^{* * *} \\
(1,575)\end{array}$ & $\begin{array}{l}2,564^{*} \\
(1,383)\end{array}$ & $\begin{array}{c}33,269 * * * \\
(3,159)\end{array}$ & $\begin{array}{c}-7,410 * * \\
(2,984)\end{array}$ & $\begin{array}{l}-1,513 \\
(1,597)\end{array}$ & $\begin{array}{c}539.0 \\
(1,923)\end{array}$ & $\begin{array}{c}-7,837 * * \\
(3,364)\end{array}$ & $\begin{array}{l}-3,167 \\
(2,557)\end{array}$ \\
\hline Hispanic Male Enrollment & $\begin{array}{c}3,781^{* * *} \\
(1,027)\end{array}$ & $\begin{array}{c}3,428 * * * \\
(1,029)\end{array}$ & $\begin{array}{c}16,944^{* * *} \\
(2,284)\end{array}$ & $\begin{array}{c}23,767 * * * \\
(3,004)\end{array}$ & $\begin{array}{c}223.2 \\
(1,085)\end{array}$ & $\begin{array}{c}2,390 \\
(1,568)\end{array}$ & $\begin{array}{l}-660.8 \\
(432.8)\end{array}$ & $\begin{array}{c}608.9 \\
(471.7)\end{array}$ \\
\hline Hispanic Female Enrollment & $\begin{array}{c}-2,442^{* * *} \\
(738.0)\end{array}$ & $\begin{array}{l}-606.0 \\
(734.0)\end{array}$ & $\begin{array}{c}-9,310^{* * *} \\
(1,480)\end{array}$ & $\begin{array}{c}-1,493 \\
(1,950)\end{array}$ & $\begin{array}{c}781.1 \\
(787.0)\end{array}$ & $\begin{array}{l}-14.42 \\
(1,102)\end{array}$ & $\begin{array}{c}352.5 \\
(321.6)\end{array}$ & $\begin{array}{c}533.8 \\
(419.9)\end{array}$ \\
\hline White Male Enrollment & $-1,326 * * *$ & 422.6 & $713.5^{*}$ & $-1,306^{*}$ & $1,734 * * *$ & 864.9 & $1,219 * * *$ & 330.2 \\
\hline
\end{tabular}




\begin{tabular}{|c|c|c|c|c|c|c|c|c|}
\hline & $(263.0)$ & $(371.0)$ & $(426.5)$ & $(708.6)$ & (307.1) & $(558.3)$ & $(209.2)$ & (299.9) \\
\hline \multirow[t]{2}{*}{ White Female Enrollment } & $419.3^{*}$ & $619.7^{* *}$ & -5.692 & 474.9 & -386.7 & 440.3 & $-668.5 * * *$ & $-478.5^{*}$ \\
\hline & (219.6) & $(285.4)$ & $(351.7)$ & $(479.2)$ & $(249.2)$ & (449.4) & $(158.8)$ & $(245.5)$ \\
\hline \multirow[t]{3}{*}{ Four-Year Institution } & $-1.032 e+06 * *$ & 248,265 & & & & & & \\
\hline & $(460,958)$ & $(921,168)$ & & & & & & \\
\hline & - & & & & & & & \\
\hline \multirow[t]{2}{*}{ Public Institution } & $4.920 \mathrm{e}+06 * * *$ & $-170,093$ & & & & & & \\
\hline & $(379,343)$ & $(2.894 e+06)$ & & & & & & \\
\hline \multirow[t]{2}{*}{ Overall Total by Type } & $-71,478$ & $109,205^{* * *}$ & $-337,328 * * *$ & $-40,189$ & $208,762 * *$ & $144,368 * *$ & 35,546 & 193,486 \\
\hline & $(73,096)$ & $(41,071)$ & $(92,201)$ & $(60,320)$ & $(99,024)$ & $(70,495)$ & $(202,434)$ & $(143,144)$ \\
\hline \multirow[t]{2}{*}{ Expenses Total by Type } & $0.00387 * * *$ & $0.00253 * * *$ & $0.00672 * * *$ & -0.000299 & -0.000546 & $0.00346 * * *$ & $0.0236 * * *$ & $0.0162 *$ \\
\hline & $(0.000899)$ & $(0.000902)$ & $(0.00128)$ & $(0.00204)$ & $(0.00112)$ & $(0.00128)$ & $(0.00871)$ & $(0.00953)$ \\
\hline \multirow[t]{2}{*}{ Overall Total by State } & $256,234 * * *$ & 28,543 & $-20,599$ & $-71,349$ & $807,964 * * *$ & $261,575 * *$ & $89,083 * *$ & $-29,442$ \\
\hline & $(75,157)$ & $(44,544)$ & $(87,115)$ & $(54,975)$ & $(133,276)$ & $(111,621)$ & $(39,584)$ & $(33,986)$ \\
\hline \multirow[t]{3}{*}{ Expenses Total by State } & $0.0301 * * *$ & $0.0292^{* * *}$ & $0.0282 * * *$ & $0.0138 * * *$ & $0.0192 * * *$ & $0.0443 * * *$ & 0.00154 & $0.0154^{* * *}$ \\
\hline & $(0.00392)$ & $(0.00389)$ & (0.00491) & $(0.00485)$ & $(0.00625)$ & $(0.00954)$ & (0.00149) & $(0.00417)$ \\
\hline & - & & & & & & & \\
\hline \multirow[t]{3}{*}{ HBCU Institution } & $4.467 \mathrm{e}+06 * * *$ & & & & $-922,748$ & & $1.516 \mathrm{e}+06^{* * *}$ & \\
\hline & $(1.127 e+06)$ & & & & $(1.161 \mathrm{e}+06)$ & & $(375,547)$ & \\
\hline & & & - & & & - & - & - \\
\hline \multirow[t]{2}{*}{ Constant } & $2.574 \mathrm{e}+06 * * *$ & $-2.204 e+06$ & $1.084 \mathrm{e}+06 * *$ & $2.954 \mathrm{e}+06 * * *$ & $-660,230$ & $7.573 e+06 * * *$ & $1.693 e+06^{* * *}$ & $1.384 \mathrm{e}+06 * * *$ \\
\hline & $(589,833)$ & $(1.441 \mathrm{e}+06)$ & $(509,384)$ & $(521,835)$ & $(699,909)$ & $(1.293 e+06)$ & $(360,627)$ & $(280,195)$ \\
\hline Observations & 18,545 & 18,545 & 10,993 & 10,993 & 5,047 & 5,047 & 2,188 & 2,188 \\
\hline R-squared & 0.774 & 0.975 & 0.835 & 0.980 & 0.828 & 0.963 & 0.779 & 0.948 \\
\hline
\end{tabular}

Standard errors in

parentheses

*** $p<0.01, * * p<0.05, *$

$\mathrm{p}<0.1$ 
Table 8:

\begin{tabular}{|c|c|c|c|c|c|c|c|c|}
\hline \multicolumn{9}{|c|}{ Student Service \& Institutional Support Expenses Before \& After the DCL in 2011} \\
\hline VARIABLES & $\begin{array}{l}\text { Student Services } \\
\text { Before } 2011\end{array}$ & $\begin{array}{c}\text { Student } \\
\text { Services Before } \\
2011 \text { with F.E. }\end{array}$ & $\begin{array}{c}\text { Institutional } \\
\text { Support Before } \\
2011\end{array}$ & $\begin{array}{l}\text { Institutional } \\
\text { Support } \\
\text { Before } 2011 \\
\text { with F.E. }\end{array}$ & $\begin{array}{l}\text { Student Services } \\
\quad \text { After } 2011\end{array}$ & $\begin{array}{c}\text { Student } \\
\text { Services After } \\
2011 \text { with F.E. }\end{array}$ & $\begin{array}{c}\text { Institutional } \\
\text { Support After } \\
2011\end{array}$ & $\begin{array}{l}\text { Institutional } \\
\text { Support After } \\
2011 \text { with F.E. }\end{array}$ \\
\hline Overall Total & $\begin{array}{c}410,943 * * * \\
(29,749)\end{array}$ & $\begin{array}{l}-11,032 \\
(11,880)\end{array}$ & $\begin{array}{c}447,931 * * * \\
(51,279)\end{array}$ & $\begin{array}{c}18,262 \\
(26,043)\end{array}$ & $\begin{array}{c}302,128 * * * \\
(19,549)\end{array}$ & $\begin{array}{c}19,410^{* *} \\
(8,289)\end{array}$ & $\begin{array}{c}224,354 * * * \\
(32,021)\end{array}$ & $\begin{array}{c}-1,035 \\
(13,264)\end{array}$ \\
\hline Total Expenses & $\begin{array}{c}0.00329 * * * \\
(0.000770)\end{array}$ & $\begin{array}{c}0.0178 * * * \\
(0.000649) \\
-\end{array}$ & $\begin{array}{c}0.0410 * * * \\
(0.00133)\end{array}$ & $\begin{array}{c}0.0553 * * * \\
(0.00142)\end{array}$ & $\begin{array}{c}-0.0282 * * * \\
(0.00121)\end{array}$ & $\begin{array}{c}0.0110 * * * \\
(0.000977) \\
-\end{array}$ & $\begin{array}{c}-0.0250 * * * \\
(0.00199)\end{array}$ & $\begin{array}{c}0.0643 * * * \\
(0.00156)\end{array}$ \\
\hline Total Revenue & $\begin{array}{c}0.00656 * * * \\
(0.000502)\end{array}$ & $\begin{array}{c}0.000550 * * * \\
(0.000139)\end{array}$ & $\begin{array}{c}0.00556 * * * \\
(0.000864)\end{array}$ & $\begin{array}{c}0.000714 * * \\
(0.000305)\end{array}$ & $\begin{array}{l}0.0330 * * * \\
(0.000992)\end{array}$ & $\begin{array}{c}0.000972 * * \\
(0.000401)\end{array}$ & $\begin{array}{c}0.0624 * * * \\
(0.00163)\end{array}$ & $\begin{array}{l}-0.000888 \\
(0.000642)\end{array}$ \\
\hline Nonresident Male Enrollment & $\begin{array}{c}3,655^{* * *} \\
(1,150)\end{array}$ & $\begin{array}{c}8,609 * * * \\
(1,069)\end{array}$ & $\begin{array}{c}15,848 * * * \\
(1,982)\end{array}$ & $\begin{array}{c}455.8 \\
(2,344)\end{array}$ & $\begin{array}{c}3,511^{* * *} \\
(914.5)\end{array}$ & $\begin{array}{l}-538.6 \\
(827.0)\end{array}$ & $\begin{array}{l}-1,407 \\
(1,498)\end{array}$ & $\begin{array}{c}-3,667^{* * *} \\
(1,323)\end{array}$ \\
\hline Nonresident Female Enrollment & $\begin{array}{c}6,443 * * * \\
(1,510)\end{array}$ & $\begin{array}{c}2,427^{* *} \\
(1,170)\end{array}$ & $\begin{array}{c}20,507^{* * *} \\
(2,604)\end{array}$ & $\begin{array}{c}14,876 * * * \\
(2,565)\end{array}$ & $\begin{array}{c}6,294 * * * \\
(1,142)\end{array}$ & $\begin{array}{c}6,846^{* * *} \\
(1,108)\end{array}$ & $\begin{array}{c}29,191 * * * \\
(1,871)\end{array}$ & $\begin{array}{c}8,897^{* * *} \\
(1,773)\end{array}$ \\
\hline Black Male Enrollment & $\begin{array}{l}1,539 * \\
(883.8)\end{array}$ & $\begin{array}{c}574.3 \\
(1,110)\end{array}$ & $\begin{array}{c}5,782^{* * *} \\
(1,524)\end{array}$ & $\begin{array}{c}-6,145^{* *} \\
(2,433)\end{array}$ & $\begin{array}{l}-758.8 \\
(1,077)\end{array}$ & $\begin{array}{c}5,670 * * * \\
(1,592)\end{array}$ & $\begin{array}{c}6,656^{* * *} \\
(1,764)\end{array}$ & $\begin{array}{l}-3,197 \\
(2,548)\end{array}$ \\
\hline Black Female Enrollment & $\begin{array}{l}-309.5 \\
(446.4)\end{array}$ & $\begin{array}{c}856.0 \\
(557.9)\end{array}$ & $\begin{array}{c}285.2 \\
(769.5)\end{array}$ & $\begin{array}{c}3,496 * * * \\
(1,223)\end{array}$ & $\begin{array}{c}2,188 * * * \\
(552.9)\end{array}$ & $\begin{array}{c}792.5 \\
(781.8)\end{array}$ & $\begin{array}{c}1,939 * * \\
(905.6)\end{array}$ & $\begin{array}{c}2,879 * * \\
(1,251)\end{array}$ \\
\hline $\begin{array}{l}\text { Amer Indian/Alas Native Male } \\
\text { Enroll }\end{array}$ & $\begin{array}{l}-9,328 \\
(6,472)\end{array}$ & $\begin{array}{c}-11,863^{* *} \\
(5,654)\end{array}$ & $\begin{array}{c}-435.9 \\
(11,156)\end{array}$ & $\begin{array}{c}10,092 \\
(12,394)\end{array}$ & $\begin{array}{r}-14,487 \\
(9,423)\end{array}$ & $\begin{array}{c}978.9 \\
(7,834)\end{array}$ & $\begin{array}{l}-15,409 \\
(15,435)\end{array}$ & $\begin{array}{c}8,768 \\
(12,536)\end{array}$ \\
\hline $\begin{array}{l}\text { Amer Indian/Alas Native Female } \\
\text { Enroll }\end{array}$ & $\begin{array}{c}4,218 \\
(4,120)\end{array}$ & $\begin{array}{c}579.9 \\
(3,648)\end{array}$ & $\begin{array}{l}-3,209 \\
(7,101)\end{array}$ & $\begin{array}{l}-10,817 \\
(7,997)\end{array}$ & $\begin{array}{c}10,855^{*} \\
(5,819)\end{array}$ & $\begin{array}{l}-8,940 \\
(5,511)\end{array}$ & $\begin{array}{l}10,281 \\
(9,532)\end{array}$ & $\begin{array}{c}-16,812^{*} \\
(8,819)\end{array}$ \\
\hline Asian Male Enrollment & $\begin{array}{c}-4,082^{* * *} \\
(1,448)\end{array}$ & $\begin{array}{c}2,791 * * \\
(1,236)\end{array}$ & $\begin{array}{c}-22,768 * * * \\
(2,496)\end{array}$ & $\begin{array}{c}1,936 \\
(2,709)\end{array}$ & $\begin{array}{c}-2,735^{*} \\
(1,597)\end{array}$ & $\begin{array}{c}-1,205 \\
(1,704)\end{array}$ & $\begin{array}{c}-28,907 * * * \\
(2,616)\end{array}$ & $\begin{array}{c}5,639 * * \\
(2,726)\end{array}$ \\
\hline Asian Female Enrollment & $\begin{array}{c}6,027^{* * *} \\
(1,285)\end{array}$ & $\begin{array}{l}-1,531 \\
(1,068)\end{array}$ & $\begin{array}{c}13,436^{* * * *} \\
(2,216)\end{array}$ & $\begin{array}{l}4,118^{*} \\
(2,341)\end{array}$ & $\begin{array}{c}10,309 * * * \\
(1,519)\end{array}$ & $\begin{array}{c}-8,732 * * * \\
(1,681)\end{array}$ & $\begin{array}{c}25,991 * * * \\
(2,488)\end{array}$ & $\begin{array}{l}-4,986^{*} \\
(2,690)\end{array}$ \\
\hline Hispanic Male Enrollment & $\begin{array}{l}-693.1 \\
(966.3)\end{array}$ & $\begin{array}{c}3,240 * * * \\
(1,071)\end{array}$ & $\begin{array}{c}946.4 \\
(1,666)\end{array}$ & $\begin{array}{c}7,148 * * * \\
(2,347)\end{array}$ & $\begin{array}{l}-852.7 \\
(987.7)\end{array}$ & $\begin{array}{c}1,124 \\
(1,612)\end{array}$ & $\begin{array}{c}7,695^{* * *} \\
(1,618)\end{array}$ & $\begin{array}{l}4,277^{*} \\
(2,579)\end{array}$ \\
\hline Hispanic Female Enrollment & $\begin{array}{c}1,075 \\
(658.8)\end{array}$ & $\begin{array}{c}1,787 * * \\
(725.9)\end{array}$ & $\begin{array}{l}-371.8 \\
(1,136)\end{array}$ & $\begin{array}{l}-1,679 \\
(1,591)\end{array}$ & $\begin{array}{c}1,670 * * \\
(732.4)\end{array}$ & $\begin{array}{l}1,941^{*} \\
(1,114)\end{array}$ & $\begin{array}{c}-5,690 * * * \\
(1,200)\end{array}$ & $\begin{array}{l}-33.82 \\
(1,783)\end{array}$ \\
\hline
\end{tabular}




\begin{tabular}{|c|c|c|c|c|c|c|c|c|}
\hline White Male Enrollment & $\begin{array}{c}222.5 \\
(213.1)\end{array}$ & $\begin{array}{c}1,619 * * * \\
(285.0)\end{array}$ & $\begin{array}{c}-2,080 * * * \\
(367.3)\end{array}$ & $\begin{array}{c}400.2 \\
(624.8)\end{array}$ & $\begin{array}{c}87.43 \\
(252.6)\end{array}$ & $\begin{array}{c}-2,069 * * * \\
(505.8)\end{array}$ & $\begin{array}{l}-465.3 \\
(413.7)\end{array}$ & $\begin{array}{c}2,455^{* * *} \\
(809.4)\end{array}$ \\
\hline White Female Enrollment & $\begin{array}{c}279.2 \\
(180.9)\end{array}$ & $\begin{array}{c}-1,534 * * * \\
(238.9)\end{array}$ & $\begin{array}{c}315.7 \\
(311.8)\end{array}$ & $\begin{array}{l}-510.3 \\
(523.7)\end{array}$ & $\begin{array}{c}1,357 * * * \\
(211.2)\end{array}$ & $\begin{array}{c}3,353 * * * \\
(346.6)\end{array}$ & $\begin{array}{c}52.93 \\
(346.0)\end{array}$ & $\begin{array}{l}-942.0 * \\
(554.7)\end{array}$ \\
\hline Public Institution & $\begin{array}{c}- \\
3.779 \mathrm{e}+06 * * * \\
(329,665)\end{array}$ & $\begin{array}{c}112,568 \\
(2.986 e+06)\end{array}$ & $\begin{array}{c}- \\
5.081 \mathrm{e}+06 * * * \\
(568,255)\end{array}$ & $\begin{array}{c}1.304 e+06 \\
(6.547 e+06)\end{array}$ & $\begin{array}{c}- \\
5.262 \mathrm{e}+06 * * * \\
(368,655)\end{array}$ & $\begin{array}{c}-1.914 e+06 \\
(3.067 e+06)\end{array}$ & $\begin{array}{c}- \\
4.560 \mathrm{e}+06^{* * *} \\
(603,853)\end{array}$ & $\begin{array}{l}-2.207 e+06 \\
(4.908 e+06)\end{array}$ \\
\hline HBCU Institution & $\begin{array}{c}829,478 \\
(1.043 e+06)\end{array}$ & & $\begin{array}{c}4.646 \mathrm{e}+06 * * * \\
(1.798 \mathrm{e}+06)\end{array}$ & & $\begin{array}{c}772,064 \\
(1.110 e+06)\end{array}$ & & $\begin{array}{c}5.751 \mathrm{e}+06 * * * \\
(1.818 \mathrm{e}+06)\end{array}$ & \\
\hline Overall Total by Type & $\begin{array}{c}1.905 e+06^{* * *} \\
(137,049)\end{array}$ & $\begin{array}{l}-167,982 \\
(109,074)\end{array}$ & $\begin{array}{c}1.960 \mathrm{e}+06^{* * *} \\
(236,237)\end{array}$ & $\begin{array}{c}-461,467^{*} \\
(239,112)\end{array}$ & $\begin{array}{c}549,291 * * * \\
(59,483)\end{array}$ & $\begin{array}{c}232,010 * * * \\
(51,781)\end{array}$ & $\begin{array}{c}274,827^{* * *} \\
(97,433)\end{array}$ & $\begin{array}{c}68,823 \\
(82,861)\end{array}$ \\
\hline Expenses Total by Type & $\begin{array}{c}-0.00645^{* * *} \\
(0.00105)\end{array}$ & $\begin{array}{c}0.00239 * * * \\
(0.000723)\end{array}$ & $\begin{array}{c}-0.00717 * * * \\
(0.00181)\end{array}$ & $\begin{array}{c}0.00756 * * * \\
(0.00158)\end{array}$ & $\begin{array}{c}-0.00394 * * * \\
(0.000781)\end{array}$ & $\begin{array}{c}0.0157^{* * *} \\
(0.00304)\end{array}$ & $\begin{array}{l}-0.000531 \\
(0.00128)\end{array}$ & $\begin{array}{c}0.0150 * * * \\
(0.00487)\end{array}$ \\
\hline Overall Total by State & $\begin{array}{c}673,668 * * * \\
(109,118)\end{array}$ & $\begin{array}{l}110,982 \\
(68,879)\end{array}$ & $\begin{array}{c}759,839 * * * \\
(188,091)\end{array}$ & $\begin{array}{c}116,069 \\
(150,997)\end{array}$ & $\begin{array}{c}269,102 * * * \\
(62,060)\end{array}$ & $\begin{array}{c}165,715^{* * *} \\
(38,536)\end{array}$ & $\begin{array}{c}248,767^{* *} \\
(101,653)\end{array}$ & $\begin{array}{c}160,486 * * * \\
(61,666)\end{array}$ \\
\hline Expenses Total by State & $\begin{array}{c}0.0231 * * * \\
(0.00389) \\
-\end{array}$ & $\begin{array}{c}0.0606 * * * \\
(0.00299)\end{array}$ & $\begin{array}{c}0.0466 * * * \\
(0.00671) \\
-\end{array}$ & $\begin{array}{c}0.0568 * * * \\
(0.00656)\end{array}$ & $\begin{array}{c}0.00974 * * * \\
(0.00371)\end{array}$ & $\begin{array}{c}0.00508 \\
(0.00714)\end{array}$ & $\begin{array}{c}0.0317 * * * \\
(0.00607)\end{array}$ & $\begin{array}{l}-0.0105 \\
(0.0114)\end{array}$ \\
\hline Constant & $\begin{array}{c}2.156 \mathrm{e}+06 * * * \\
(428,529)\end{array}$ & $\begin{array}{c}-1.491 e+06 \\
(1.027 e+06)\end{array}$ & $\begin{array}{c}2.931 \mathrm{e}+06^{* * *} \\
(738,671)\end{array}$ & $\begin{array}{c}-2.051 e+06 \\
(2.252 e+06)\end{array}$ & $\begin{array}{c}1.035 e+06^{* *} \\
(460,190)\end{array}$ & $\begin{array}{c}1.925 e+06 \\
(1.439 e+06)\end{array}$ & $\begin{array}{c}45,265 \\
(753,786)\end{array}$ & $\begin{array}{c}1.841 e+06 \\
(2.303 e+06)\end{array}$ \\
\hline Observations & 7,470 & 7,470 & 7,470 & 7,470 & 8,570 & 8,570 & 8,570 & 8,570 \\
\hline R-squared & 0.624 & 0.982 & 0.738 & 0.980 & 0.723 & 0.983 & 0.809 & 0.989 \\
\hline
\end{tabular}

Standard errors in

parentheses

$* * * \mathrm{p}<0.01, * * \mathrm{p}<0.05$, *

$\mathrm{p}<0.1$ 